\title{
A Review of Obsidian Studies in Iran, Provenance the Source and Prehistoric Obsidian Artifacts, Researches and Questions
}

\author{
A. ABEDI \\ Archaeometry Department, Tabriz Islamic Art University, 51385/4567, Tabriz, IRAN
}

\begin{abstract}
bsidian artifacts is frequently used materials in prehistory and found widely in archaeological sites. Provenance studies of obsidian has been an issue of intense research and debate between archaeologists and geologists. Since different provenance studies has been carried out from 1960s up to 2015 in Anatolia and Caucasus but obsidian studies in Iran is in very early stage and consider as terra incognita. Recent research on obsidian mines in Iran accompanying by prehistoric obsidian provenance studies give this opportunity to establish of a database, as well as outlining a horizon and perspective for obsidian studies in Iran. This paper will try to discuss about old and new researches on obsidian studies in Iran. After a brief introduction of obsidian studies in Anatolia and Caucasus by Renfrew, Cann and Dixon, the paper addresses some recent researches that took place concerning obsidian provenance studies in Iran. Additionally this study also look for have a review and survey on obsidian sources in Iran as well as obsidian artifacts from sites like Kul Tepe Hadishah, Dava Goz Khoy, East Chia Sabz, Choga Gholan, Tepe Boinou, surveyed sites of East of the Lake Urmia, Typical sites like Yanik, Hasanlu, Pisdeli, and relationship and comparison of ancient obsidian artifacts with known sources in order to studying obsidian sources and provenance of obsidian artifacts in Iran. This research proved that most of the analyzed obsidian artifacts of Iranian archaeological sites originated and imported from Caucasus and Anatolia in line with long-term inter-regional trade, although a handful of obsidian mines and sources have been brought to light in NW Iran that could be considered as second part of the raw material to supply the demands of local and indigenous communities of the prehistory of Iran. The implications of the findings will discuss along with limitations and future research directions.
\end{abstract}

Keywords: Obsidian, Archaeology, Analyzing Methods, Researches, Questions

\footnotetext{
* - Corresponding author: akbar.abedi@tabriziau.ac.ir
} 


\title{
مرورى بر مطالعات أبسيدين در ايران، منشأيابى معادن و أبسيدينهاى

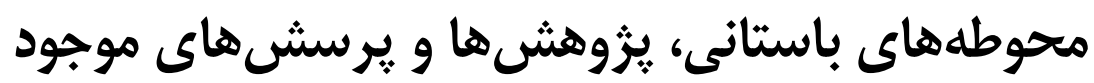

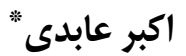

استاديار كروه باستان سنجى، دانشكده هنرهاى كاربردى، دانشكاه هنر اسلامى تبريز، تبريز، ايران

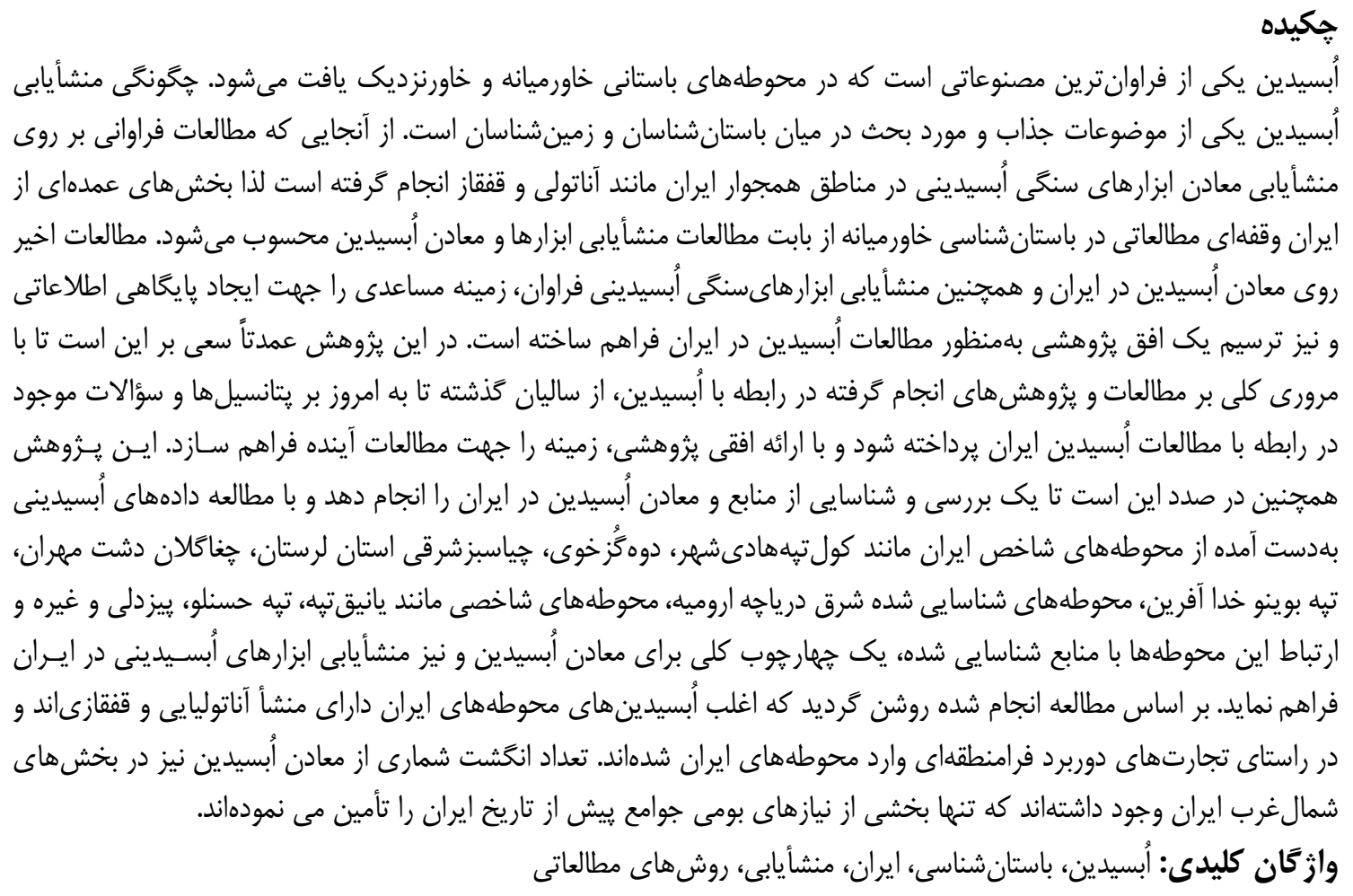

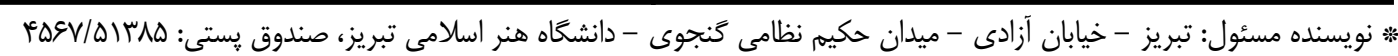
ايميل: akbar.abedi@ttabriziau.ac.ir 
همكاران در رابطه با تجارت و نوع مهاجرتهـا در دوره

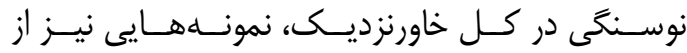

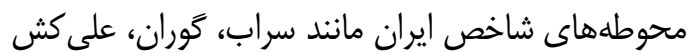

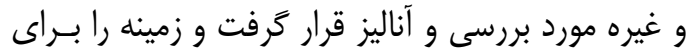

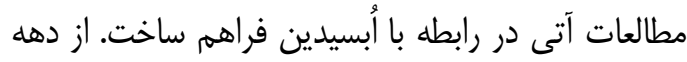
99 19 ميلادى تا دهه • 19V همانند ساير مناطق خـاور نزديك اين مطالعات ادامه يافت و از دهه •ـ191 تا اوايل قرن آ اين مطالعات با وقفهاى طولانى روبرو گرديد و

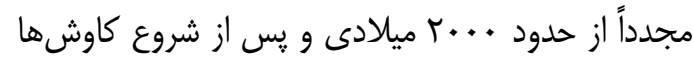

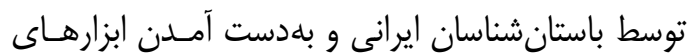

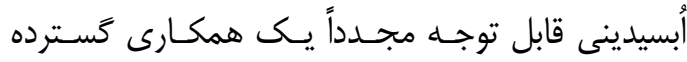
آكادميك قابل توجهى بين يزوهشخران ايرانى و محققان مان خارج از ايران برقرار گرديد و اين مسأله موجب تردين ترديد تاني يزوهشهاى علمى دوجانبهاى در اين مقطع بــانه انجـام

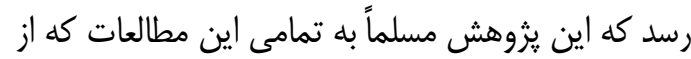

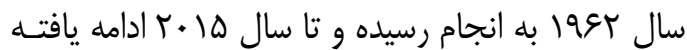

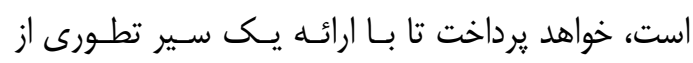

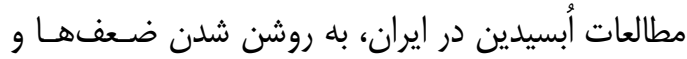
سوالات موجود بيشرو بيردازد.

\section{ץ- اولين شواهد أبسـيدين در محوطـهـهـاى باستانى - معادن أبسيدين}

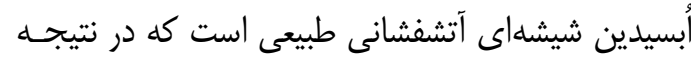
سرمايش سريع كدازه ناروان و جسبناك تركيبات ريوليتى

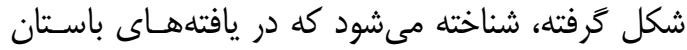

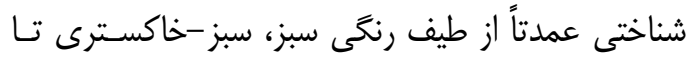

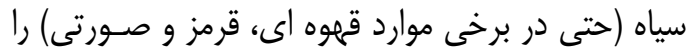

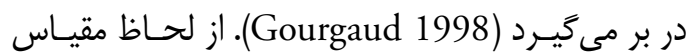

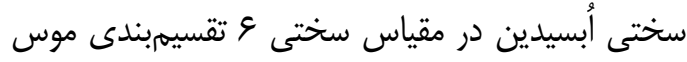

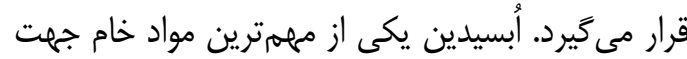

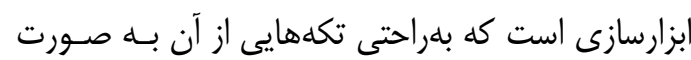

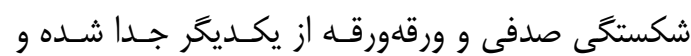
لبههاى بسيار تيزى را براى كاربردهاى مختلـف ايجـاد

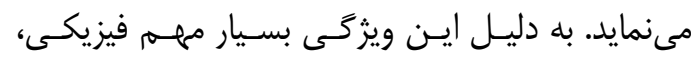

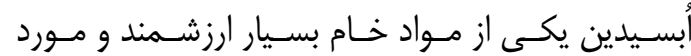

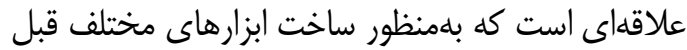
از اختراع فلز در طول دوران باستان مورد اسـتفاده قـرار

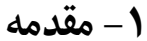

اقوام ييش از تاريخ خاورنزديــ و خاورميانـهـ از دريـاى اثه در غرب تا درياىخـزر در شـرق و نيـز از منطقـهـ قفقـاز در شمال تا خليجفـارس در جنـوب اسـتفادهــاى متعـددى از

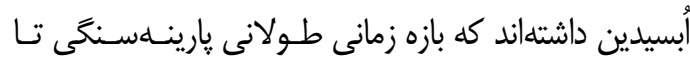

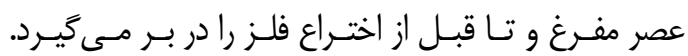

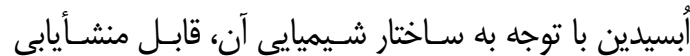

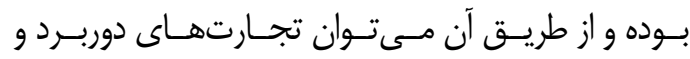

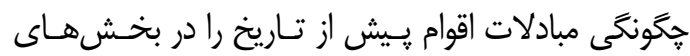
مختلـف خاورميانـهـ و خاورنزديـــ بازسـازى نمـود و وايـن

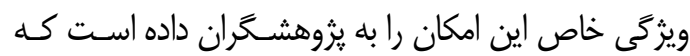
ارتباطات و فعاليتهاى تجارى مختلفى كه در اين منـاطق

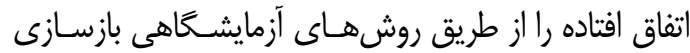
نماينـد (Chataigner et al., 1998). از طـرف ديخـر تـا

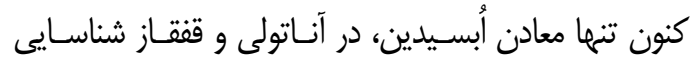

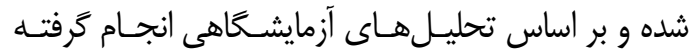

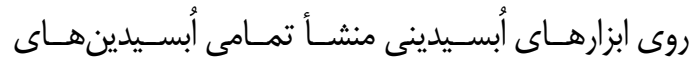

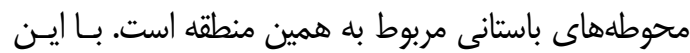

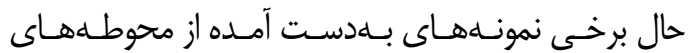

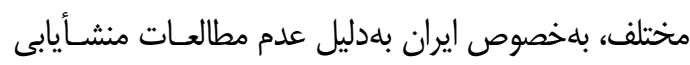

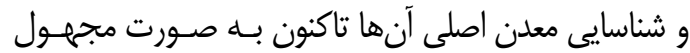

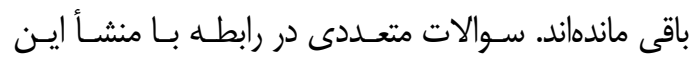
مصنوعات وجود دارد از جمله اينكـهـ آيـا در كنـار مبـادلات التهات

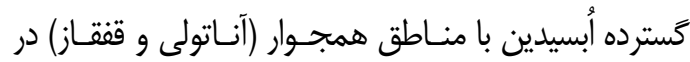

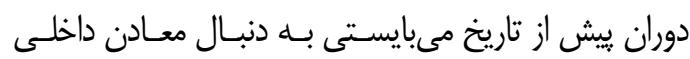

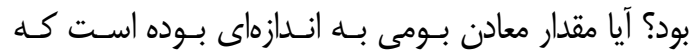

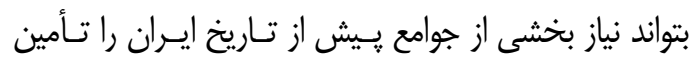

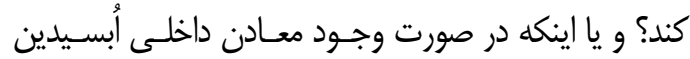
جه مكانيزمهاى تجارى بومى و منطقادى در كنار مبـادلات فرامنطقاهى وجود داشته است؟ اين سـوالات و بسـيارى از

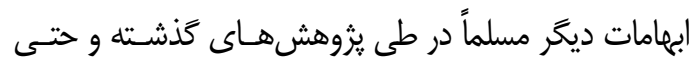

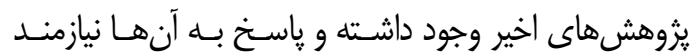

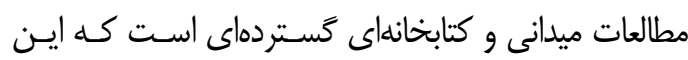

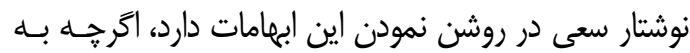

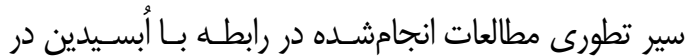
خاورميانه و خاورنزديك نيز اشاراتى خواهد رفت.

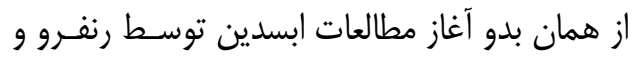


كه اصلىترين معادن موجود را مىتوان در: شـرق ارويـا e.g., Thorpe et al., 1984, Constantinescu et ) (al., 2002, Rosania et al., 2008 e.g., Merrick and Brown 1984, Merrick ) برقى et al., 1994; Vogel et al., 2006; Negash et al., 2006)، جنـوب شـبهزيــره عربستان ( e.g., Zarins ،(1990, Khalidi 2009, Khalidi et al., 2009 e.g., Kim et al., 2007; Neri ( جنـوبــرق آسـيا ،(2007, Neri et al., 2009; Ambrose et al., 2009 Kuzmin et al., 1999 Kuzmin ) خاوردور روسـيه 2009 Kuzmin and Glascock 2007, Izuho and Sato ) Summerhayes et al., ) 2007)، استراليا و اقيانوسيه 1998, Sand and Sheppard 2000, Torrence 2004, Carter et al., 2009, Torrence et al., 2009)، حوضه درياهاى مديترانه و ازه ( Francaviglia 1984, Tykot 1995, Acquafredda et al., 1999, Bellot-Gurlet et al., 2004

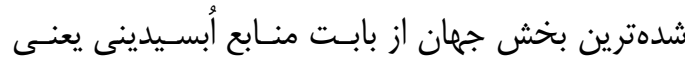

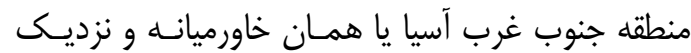

$$
\text { اشاره كرد. }
$$

\section{ץ- ييشينه مطالعات أبسيدين و يزوهشهـاى رنفرو، ديكسون و كان}

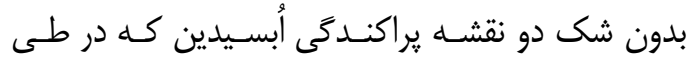
مقالهاى كه توسط جان ديكسون، جوزف كان و كولين رنفرو به نمايش درآمد مهمترين تصاويرى بودند كـه در

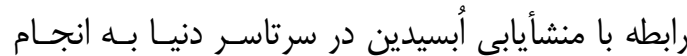

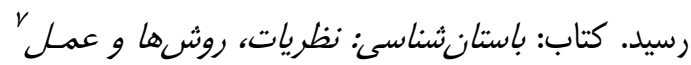

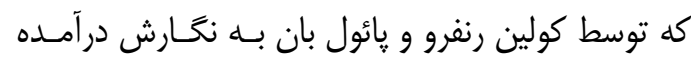

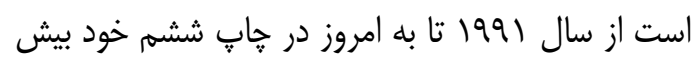

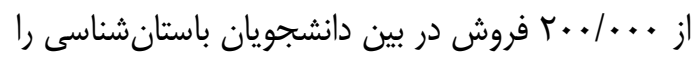

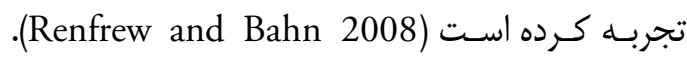
شاخصترين بخش اين كتاب در واقع بخش مربوط بـهـ

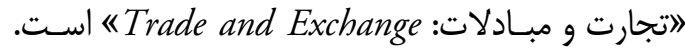
تصاوير و نقشههايى كه در اين بخش از كتـاب بـه كـار رفت (شكل () خلاصـايى از مطالعـات رنفـرو، كـان و و

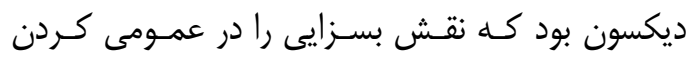

كرفته است (Abdi 2004).

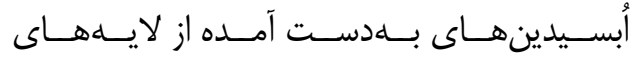

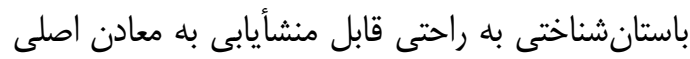

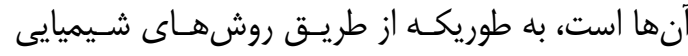

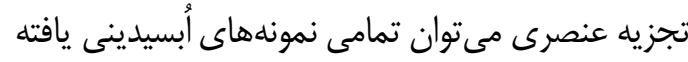

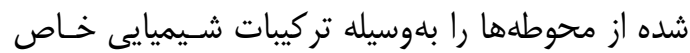
آنها از لحاظ زمين شناختى منشأيابى نمود ( Glascock

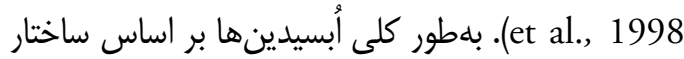

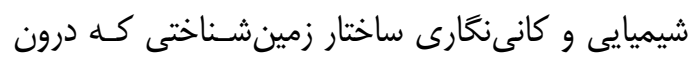

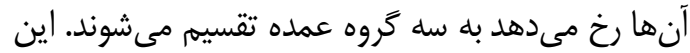
سه گروه عبارت است از عناصر آلكالين، كالى - آلكالين

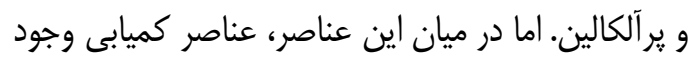
دارند كه اين امكان را فراهم مىسازند تا بتـوان معـادن

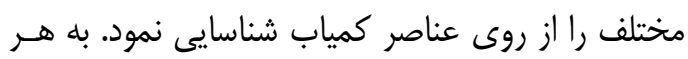

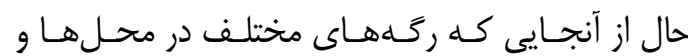
سايتهاى آتشفشانى مشابه مى توانند داراى ساختارهاى

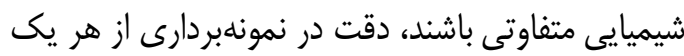

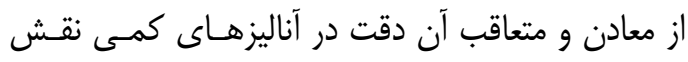
تعيين كننداى در درستى و صحت نشانهها و شاخصها براى نسبت دادن به يك منبع خاص دارند. أبسيدين يكى از اشيائى است كه از لحاظ مطالعات دارنات باستانشناختى و انسانشناختى به دليل استفاده فـراوان

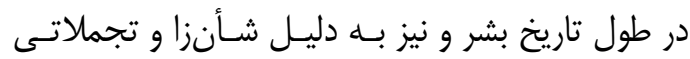

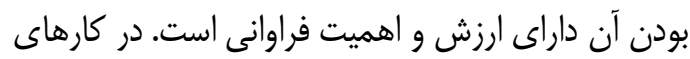

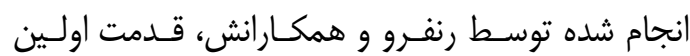

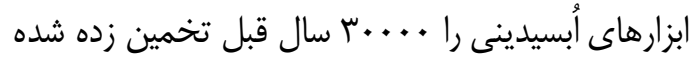

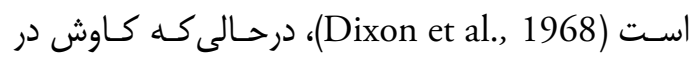
محوطه الدوى جورج' در تانزانيا دو قطعه أبسيدينى را به اله

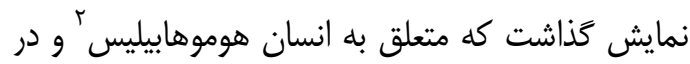

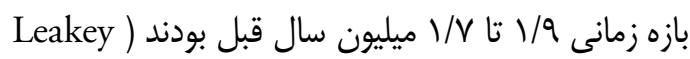

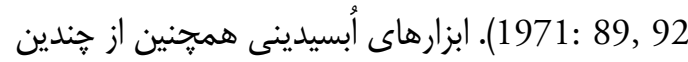

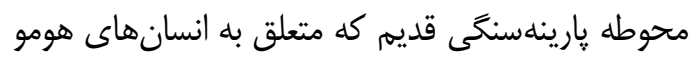

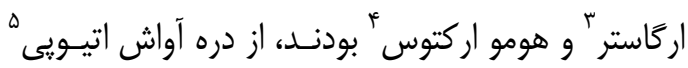
كزارش شده است (Piperno et al., 2009:126). در

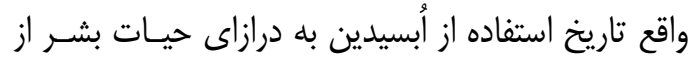
(A/ T ميليون سال قبل بوده است (Abdi 2004).

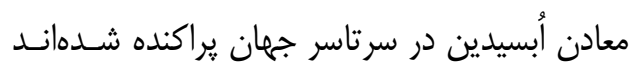


در كنار مطالعات انجام شده در رابطه بــا منشـأيابى أُبسيدين در معادن شناخته شده خاورنزديك و مديترانها،

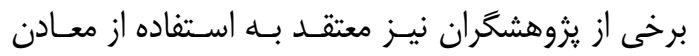

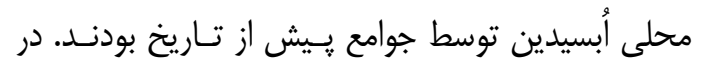

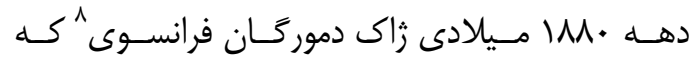

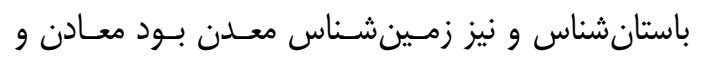

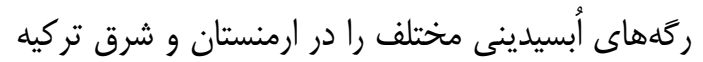

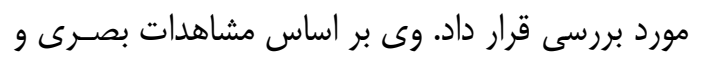

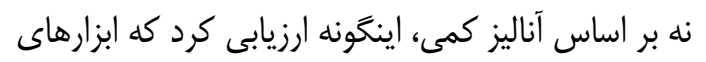

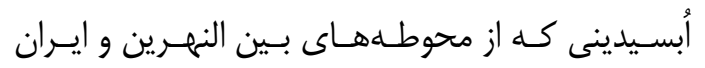

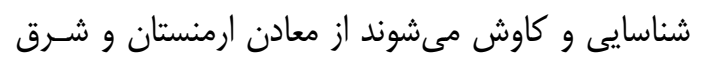

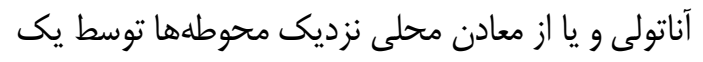
مبادله بهدست مى آيند (de Morgan 1927).

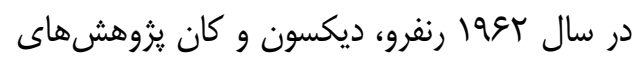
خود را در رابطه با أبسيدين آغـاز كردنسـ ( Renfrew et

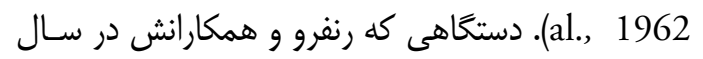

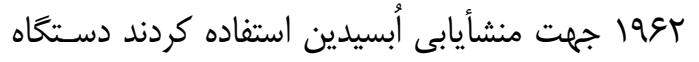

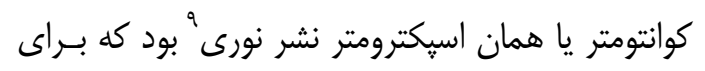

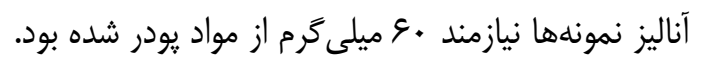

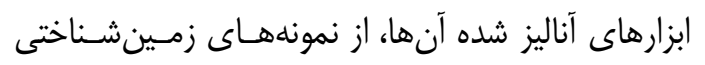
بيشتر بود و در حقيقت يراكنش أبسيدين در نوشتار سال

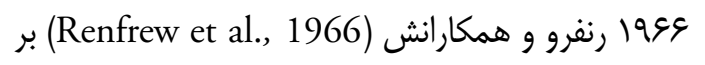

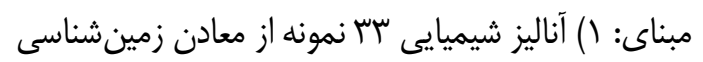

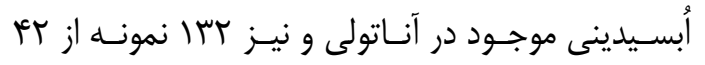

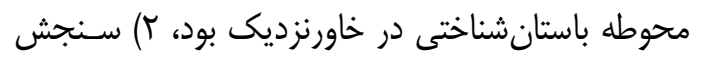

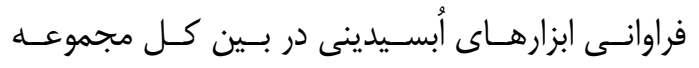

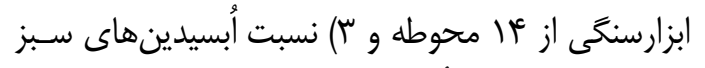

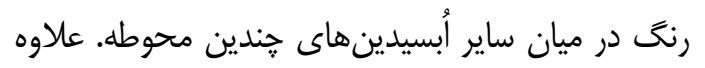

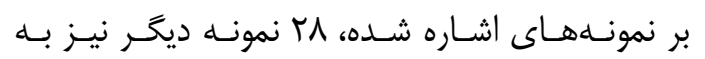

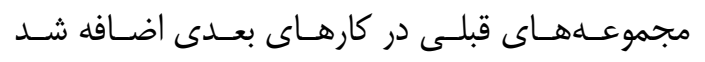

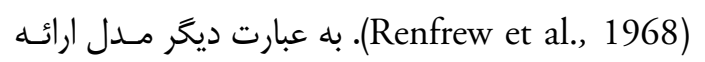

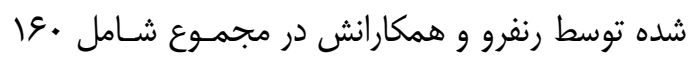

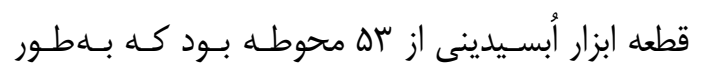

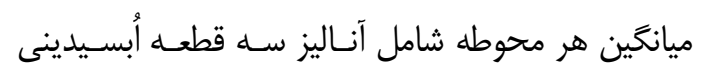

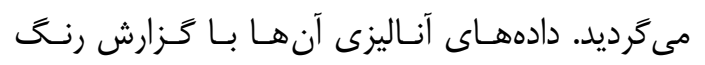

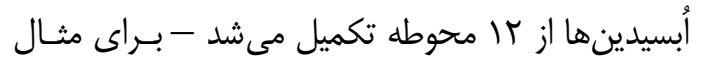

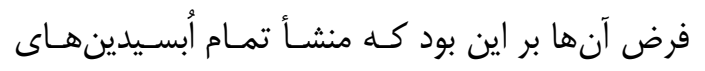

مطالعات منشـأيابى أبسـيدين داشـت (Frahm 2012).

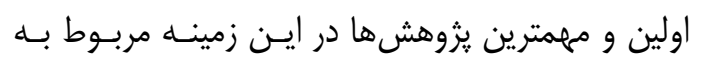

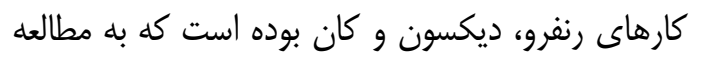

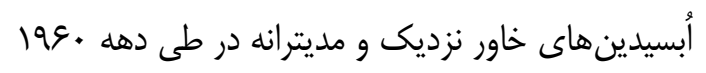

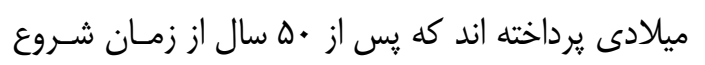

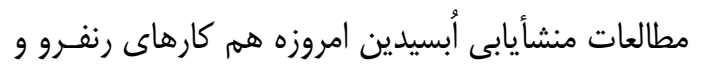

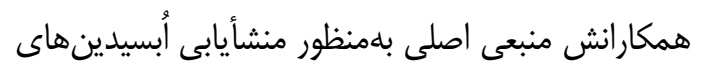

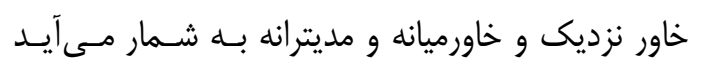
Aspinall et al., 1972; Cann and Renfrew ) 1964; Renfrew et al., 1965, 1966, 1968; Dixon et al., 1968; Cann et al., 1968, 1969; Renfrew 1969, 1970; Durrani et al., 1971; Dixon 1976; Hallam et al., 1976; Renfrew .(and Dixon 1976; Shelford et al., 1982

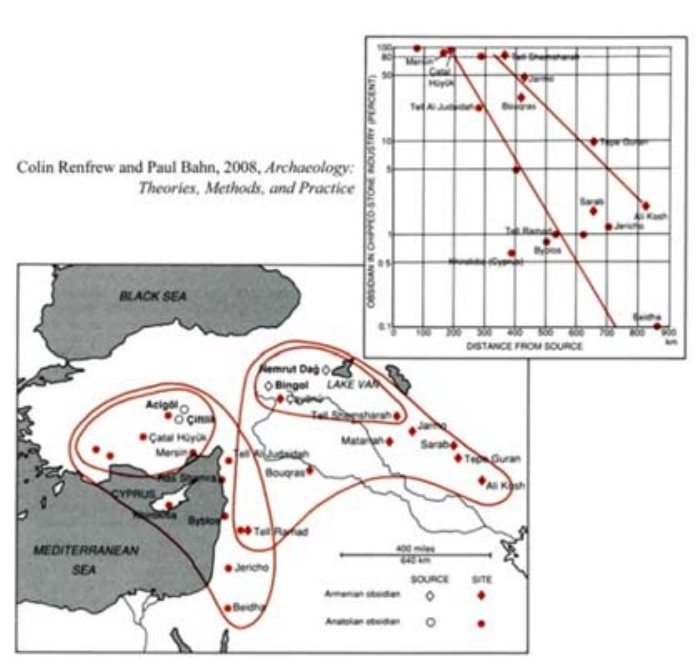

شكل ا: تجارت ابسيدين در خاورنزديك. منشأيابى ابسـيدين هـا

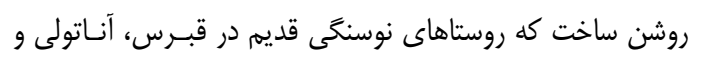

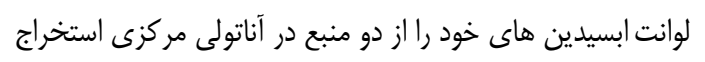

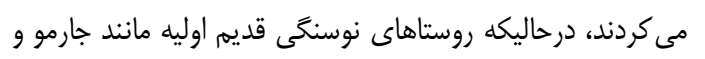

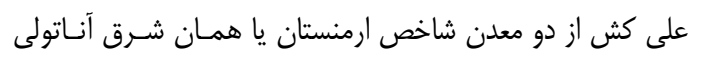

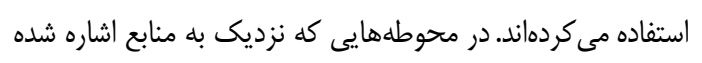

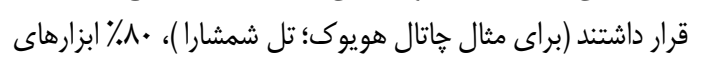

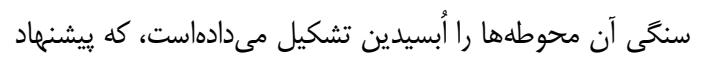

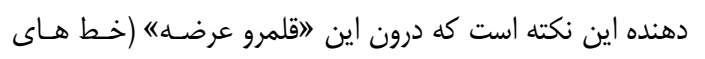

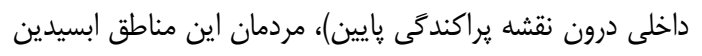

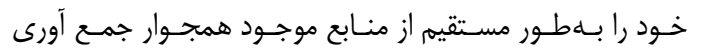

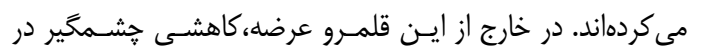

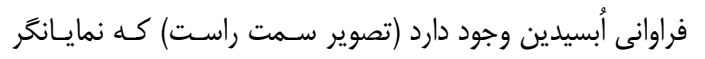
تجارت يا مبادله خط كاهشى است.

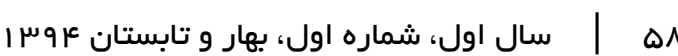


أبسيدين هاى شرق آناتولى احتمالاً توسط مهاجرت اقوام

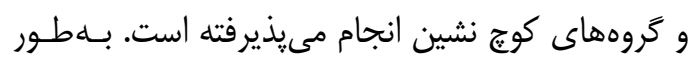

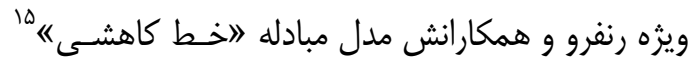

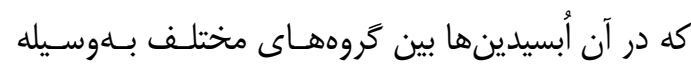

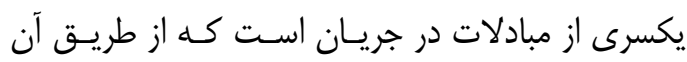

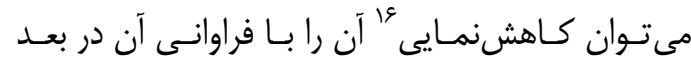

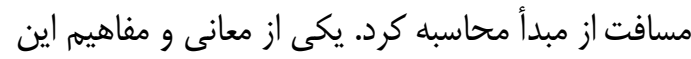

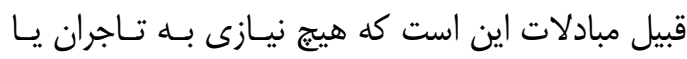

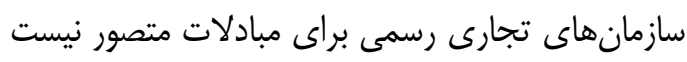

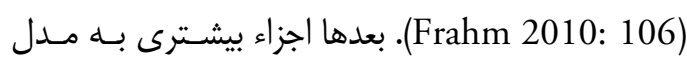

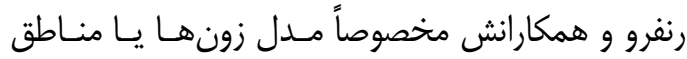

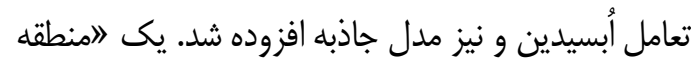

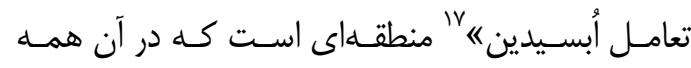

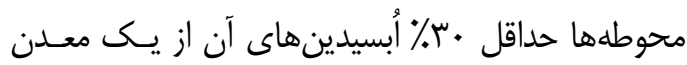

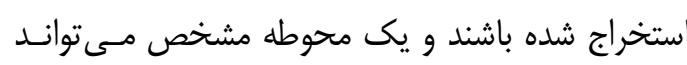

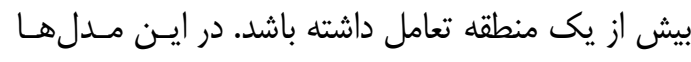
اغلب زونها و مناطق تعامل تمايل به توصيف ير اكندگى ئى

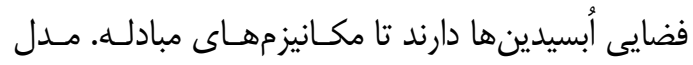

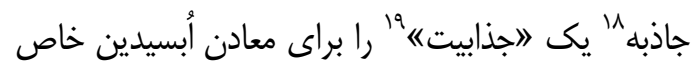

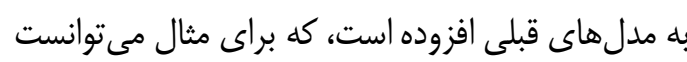

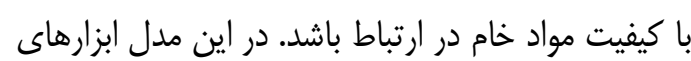

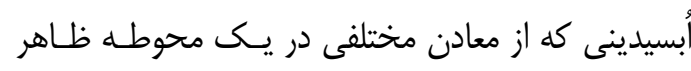

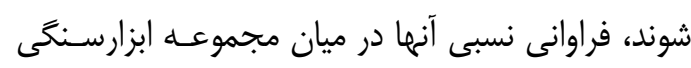

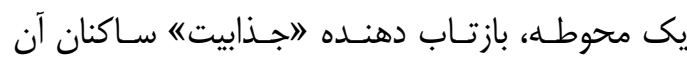

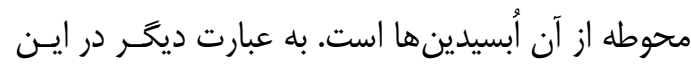
مدل بيشنهاد مى گردد كه أبسيدين هاى با جذابيت بيشتر

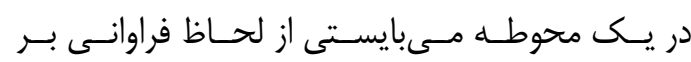

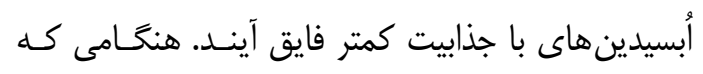

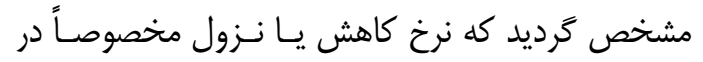

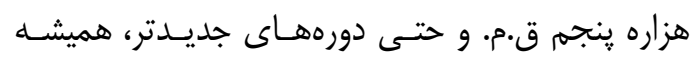
يكنواخت نبوده است، اين مدل بيشتر تصحيح شد و و مورد

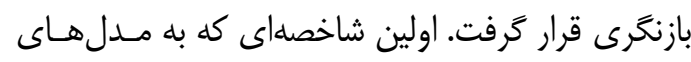

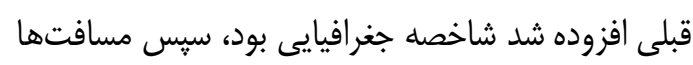

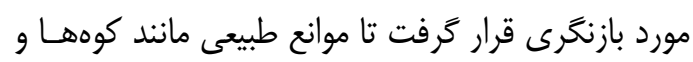

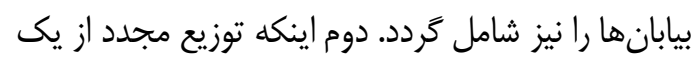
مكان مركزى، به عنوان يكى ديخر از توضيحات يِيشنهاد

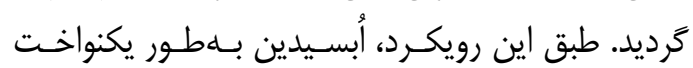

سبزرنخ معدن نمرودداغ تركيه است (شكلهاى ( و r) (Renfrew et al., 1966) رنفرو و همكارانش اثبات كردند كه بر اساس معادن

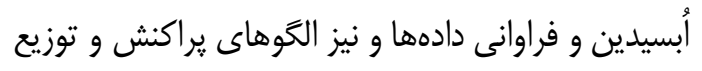

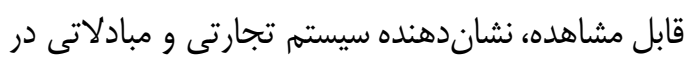

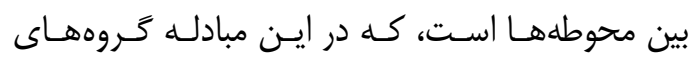
كوجنشين و يا كشاورزان يكجانشين دركير بودهاند. ايـن مئن

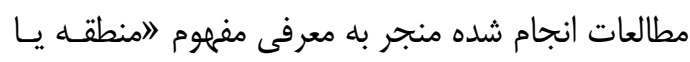

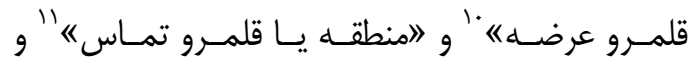

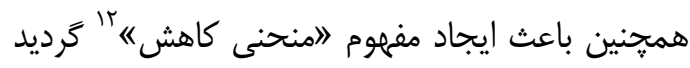

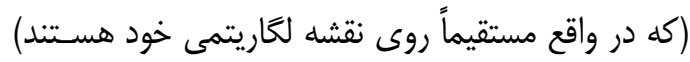

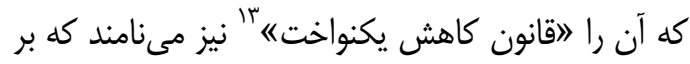

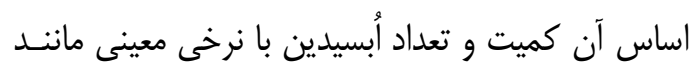

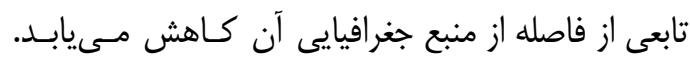

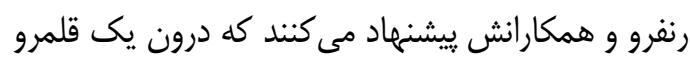

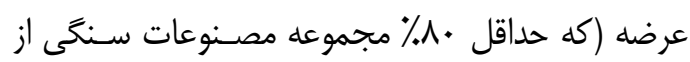

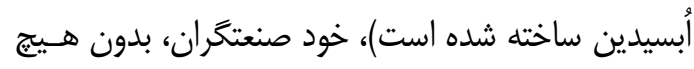

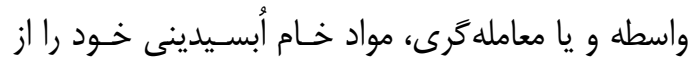

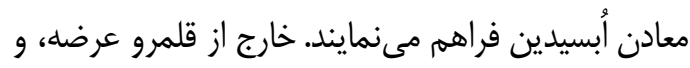

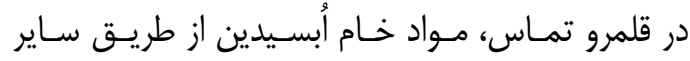

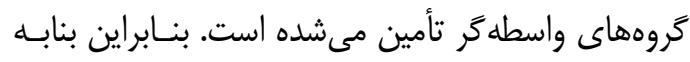

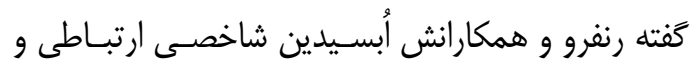

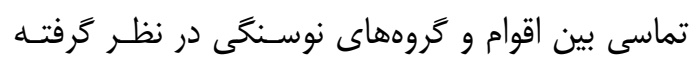

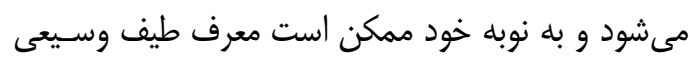

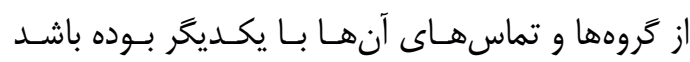

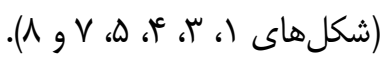
الخوى براكنش و توزيع أبسيدين رنفرو و همكارانش

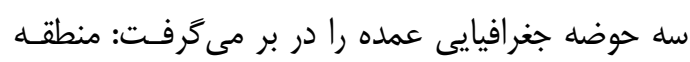

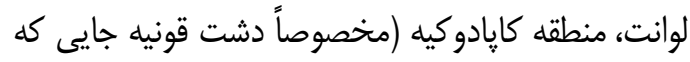

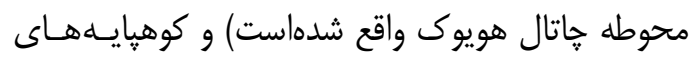

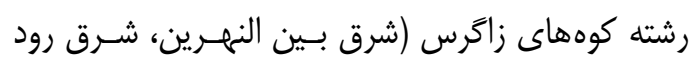

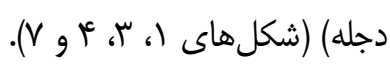

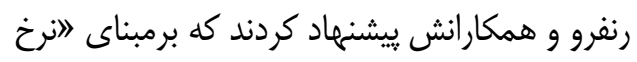

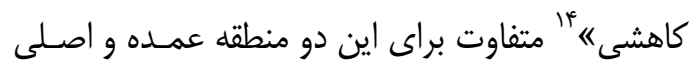

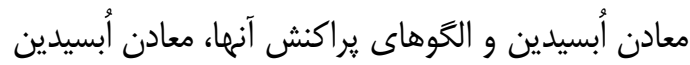

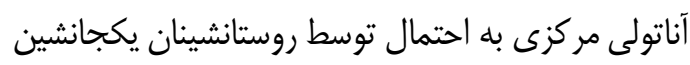

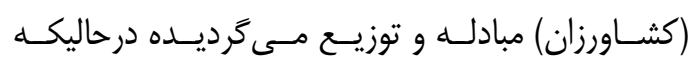




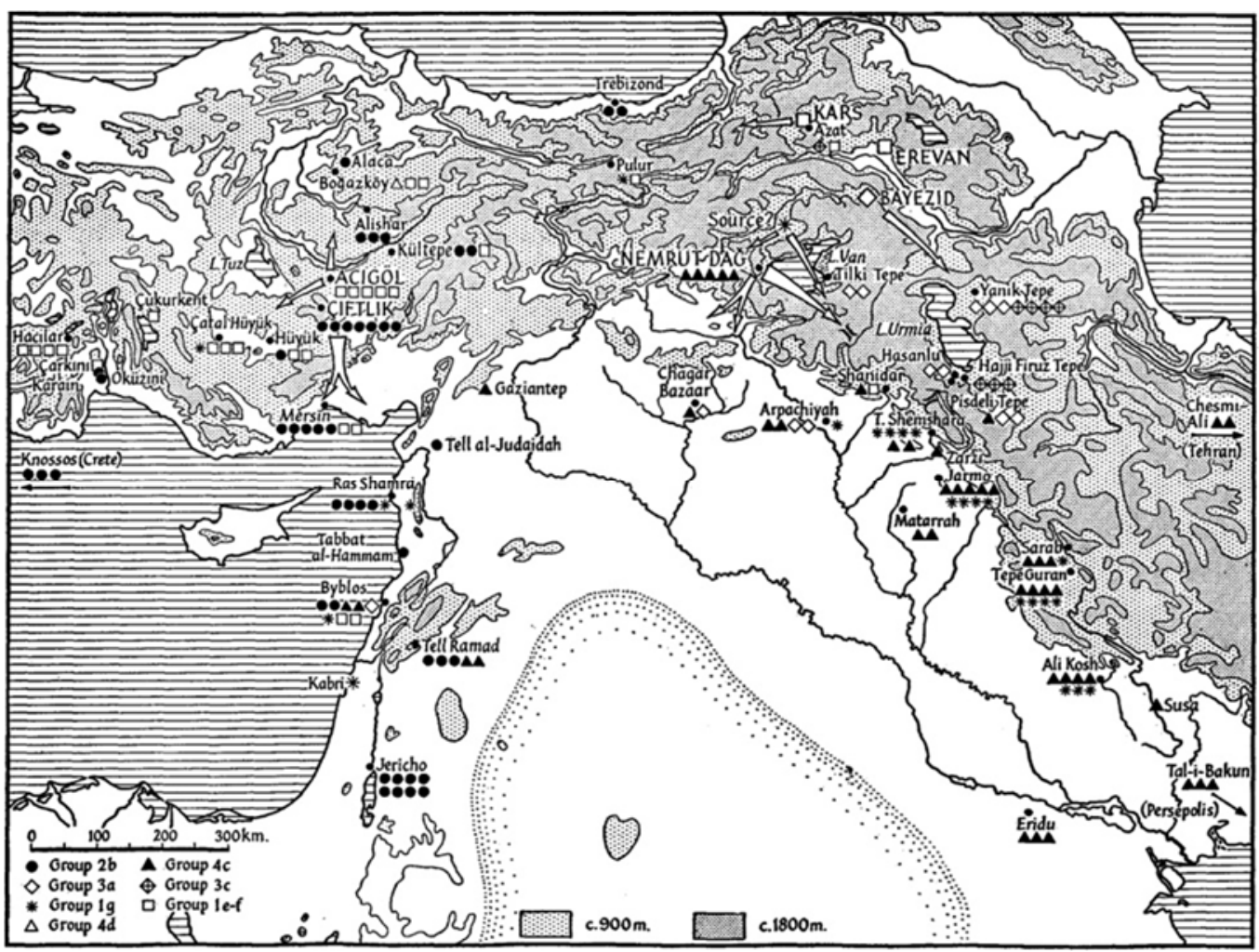

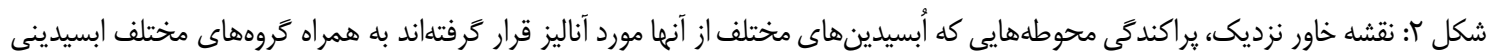

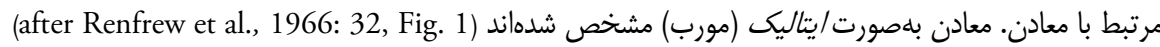

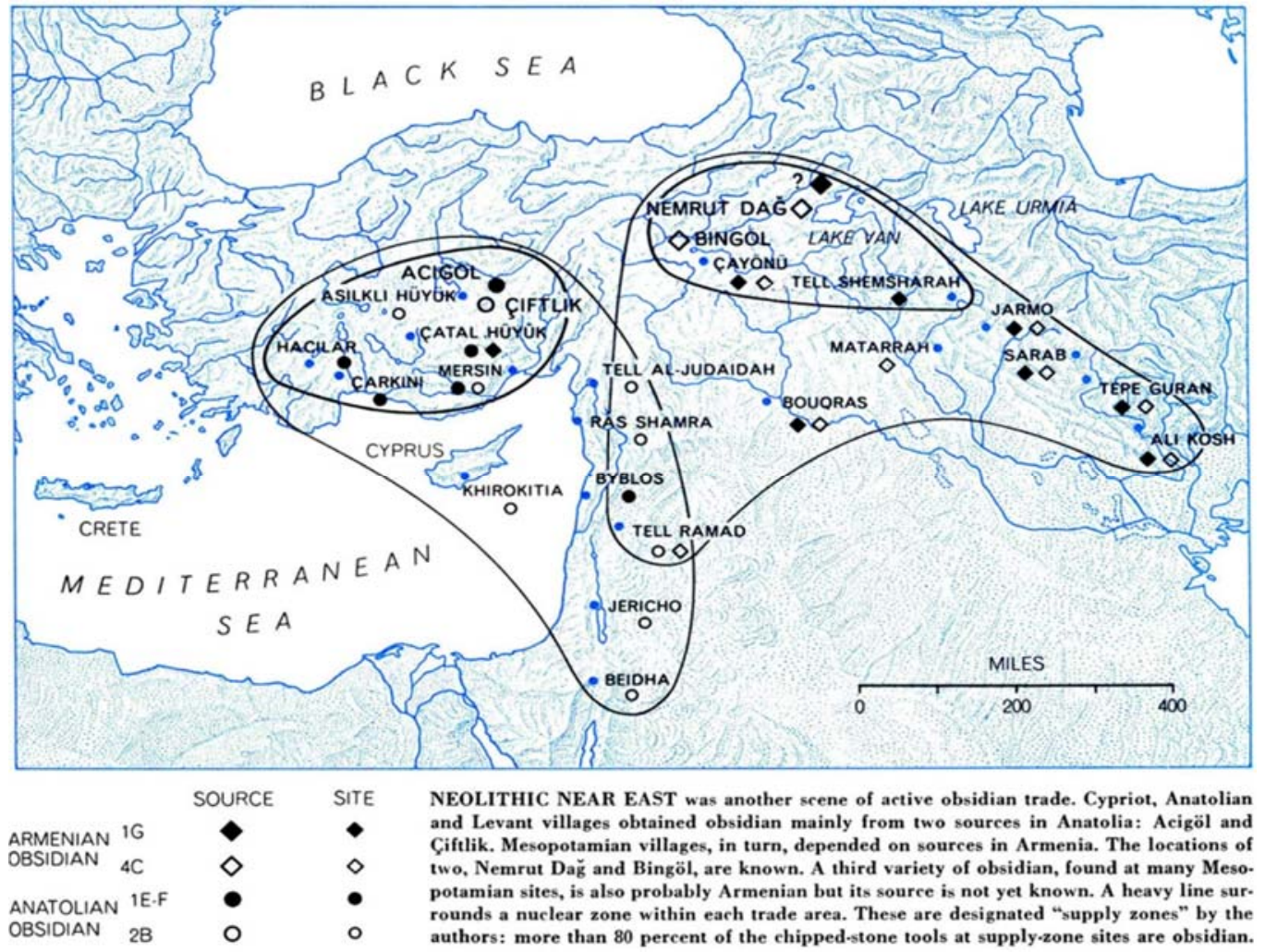

شكل "ا: نقشه (اقلمرو عرضه" و (اقلمرو تماس) أبسيدين بيشنهادى رنفرو و همكاران براى دوره نوسنكى (after Dixon et al., 1968) 


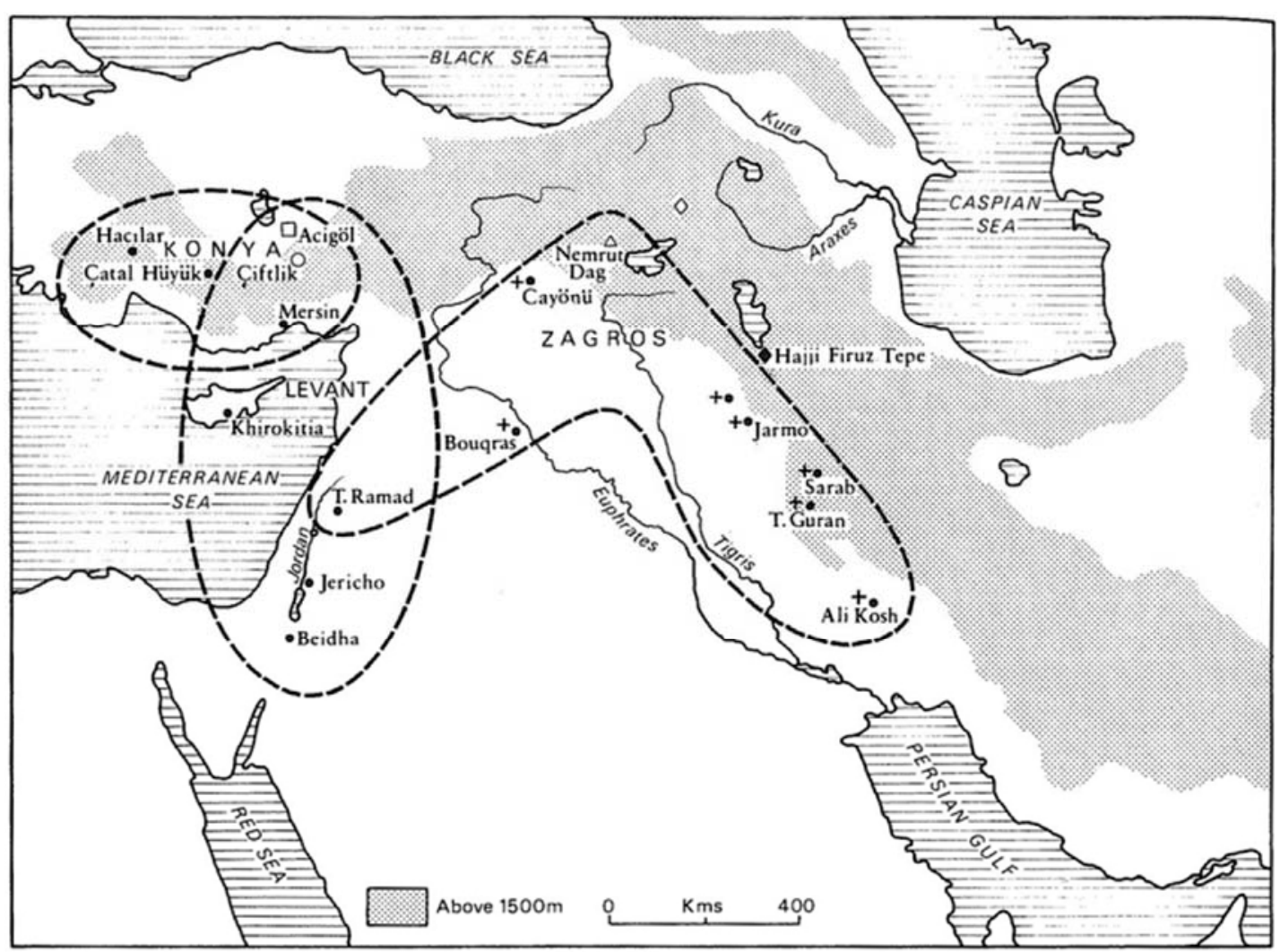

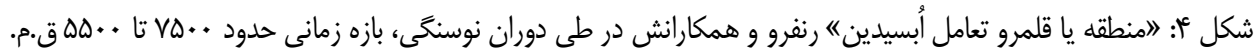
(after Renfrew and Dixon 1976)

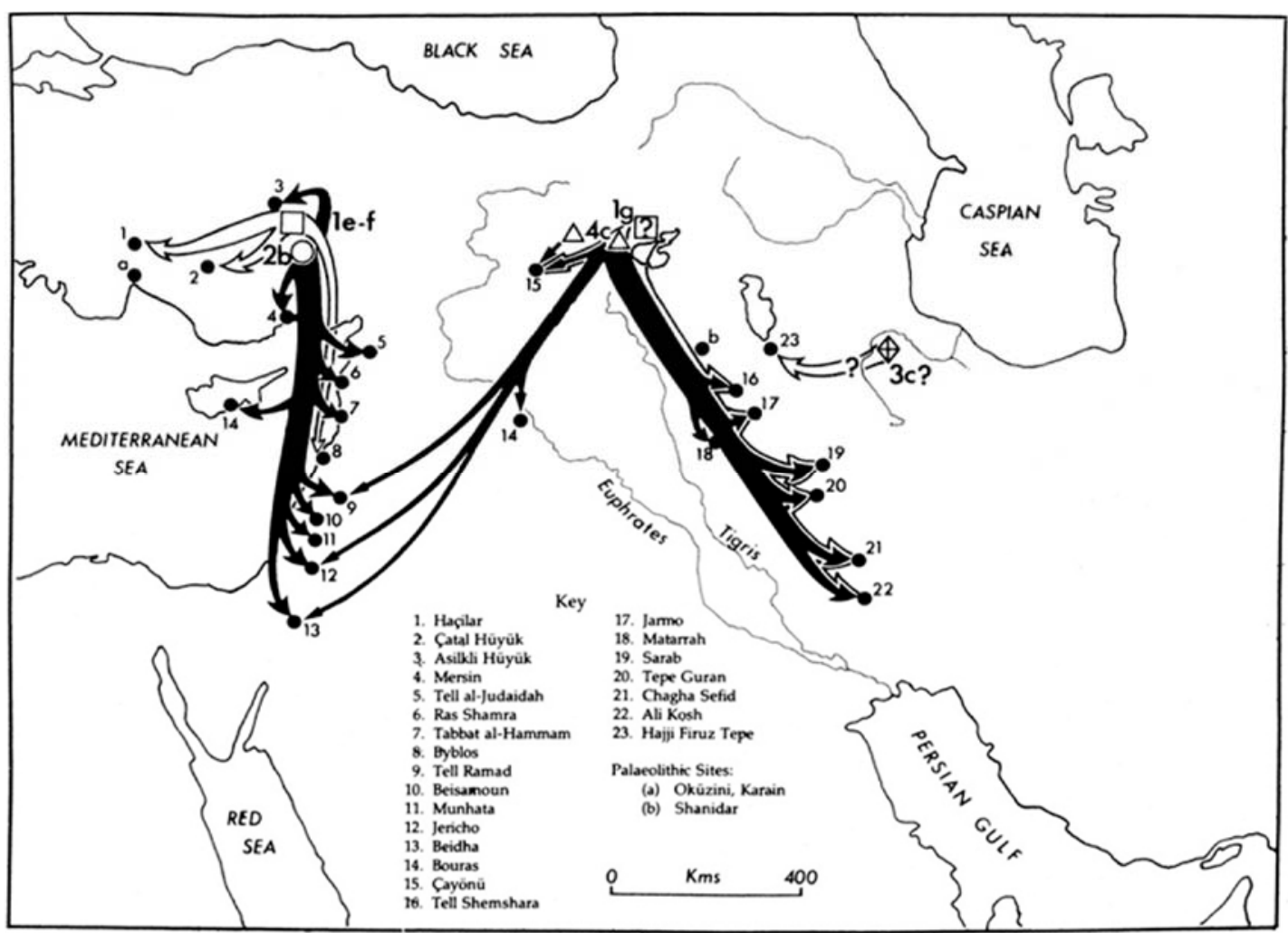

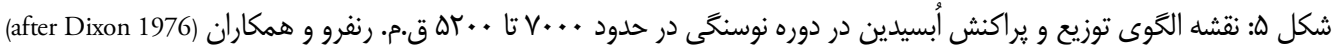

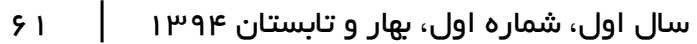




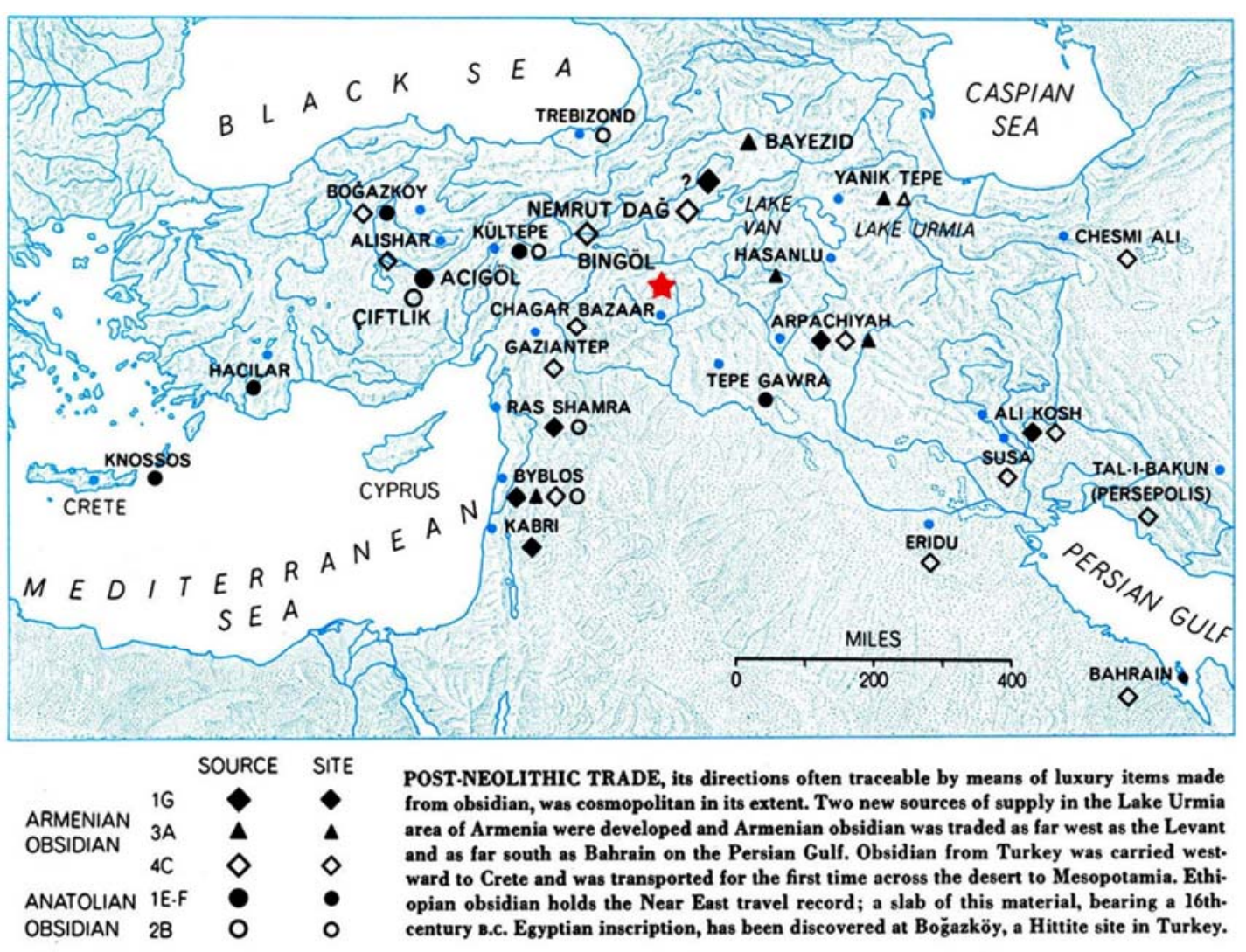

شكل \&: نقشه معادن أبسيدين رنفرو و همكاران مرتبط با محوطههاى باستانى براى دوره بعد نوسنكى (after Dixon et al.,1968)

و در يك نمودار كاهشى نشان دهند. رايت اثبات كرد كه

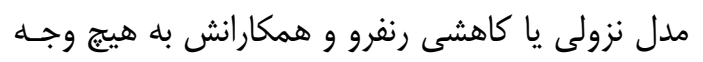

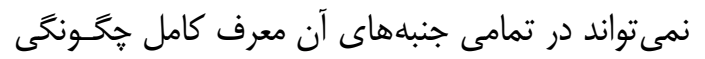

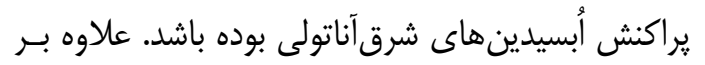

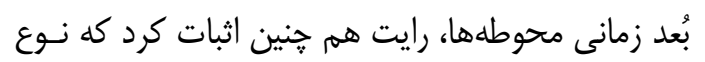

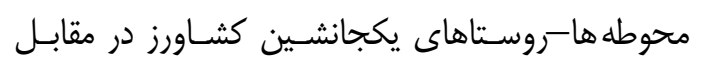

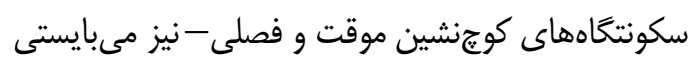
در نظر گرفته شده و مورد تمييز قرار گيرند. او همجنين

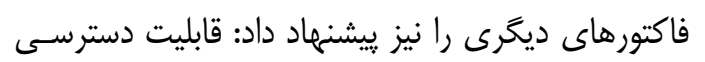
به سنگ جرت محلى هاك، استفادههاى مختلف از أبسـيدين

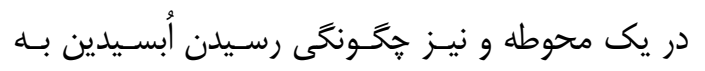

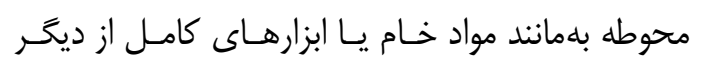

$$
\text { فاكتورهاى مورد اشاره رايت بود. }
$$

مدل "خط كاهشى" رنفرو و همكارانش توسط هـادر

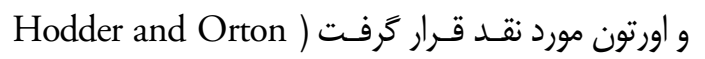

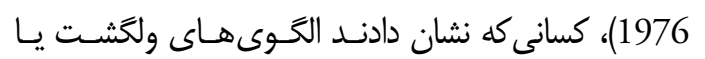

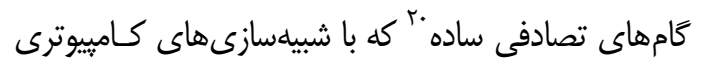

مىتوانسته در ميان مناطق مركزى در گرخش بوده باشـــ و

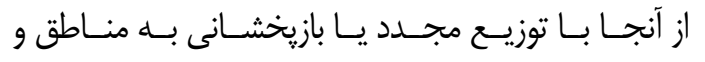

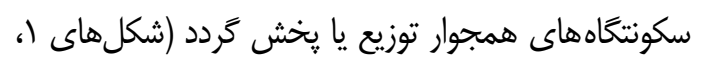

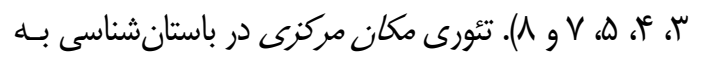
طور شاخص با مبادلات أبسيدين رشد و توسعه يافته است. ييشنهاد ديخر در اين رابطه اين بود كه أبسيدين در

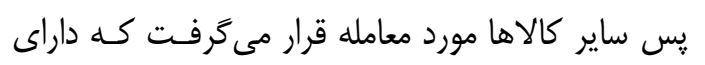

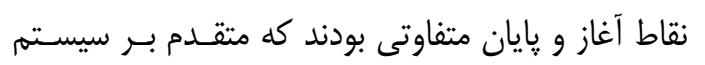

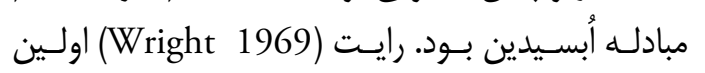

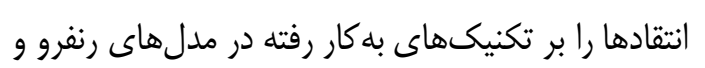

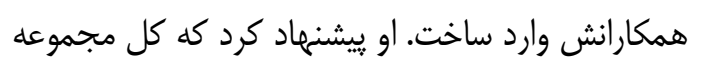

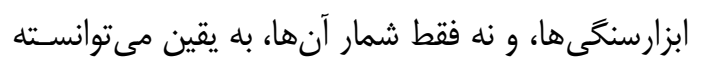

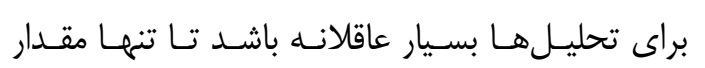
أبسيدين هايى كه در يك محوطه ظاهر مى شوند. او هم

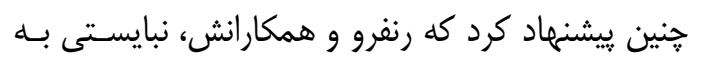

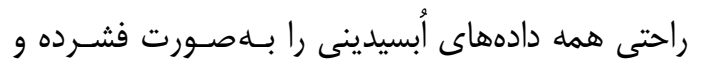
بدون در نظر گرفتن دوره زمانى در مجموعهاى قرار دادهي دادي 
تيغهها بهصورت محتمل به هزاره جهـارم و سـوم ق.م.

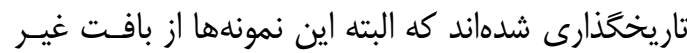

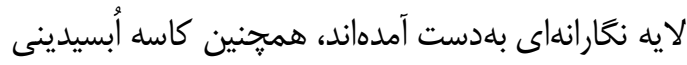

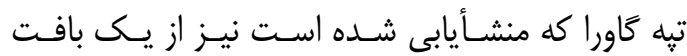

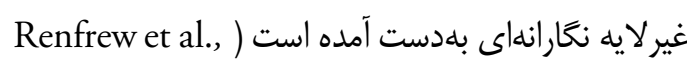
(1966, 1968; Dixon et al., 1968 بلهجاى عصر مفرغ به دوره مس و سـنَ تاريخــــارى شـاسهـا

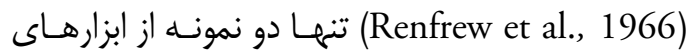

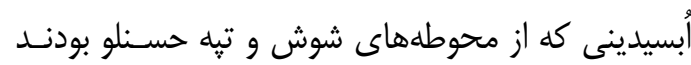

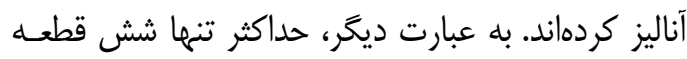

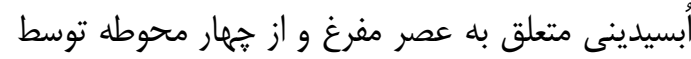

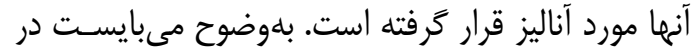
صحت نقشههاى استفاده شده توسط آنها براى دوره مهاى

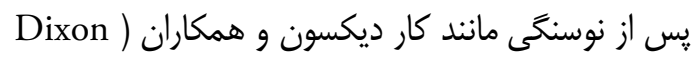

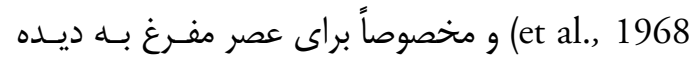

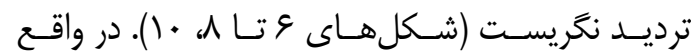

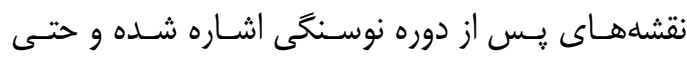

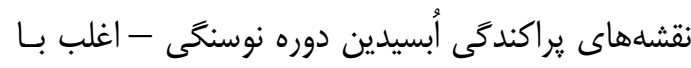

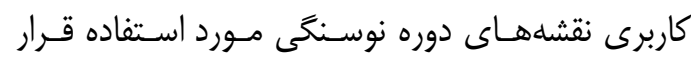

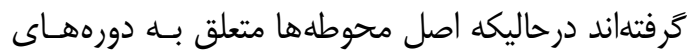

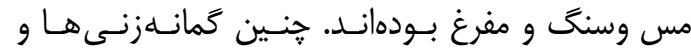
ابجاماتى به اين دليل ايجاد شدهاند كه () شمار زيادى از

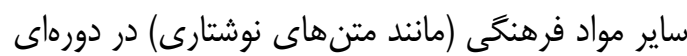

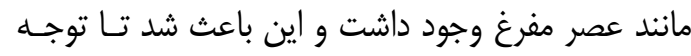
كمترى ببه ابزارهاى سنكى عصر مفرغ بــ نسه نسبت دوره

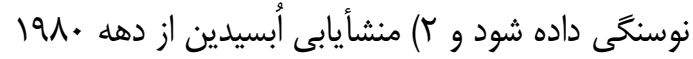

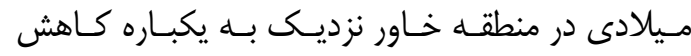
جشمخيرى يافت (Frahm 2010:109).

\section{f- أبسيدينهاى موجــود در خاورميانسه و

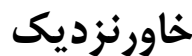

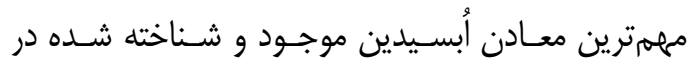
منطقه خاورنزديك در آناتولى و قفقاز قرار كرفتنهاند. هم

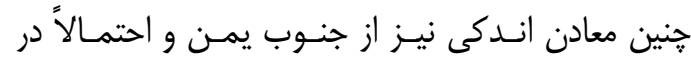

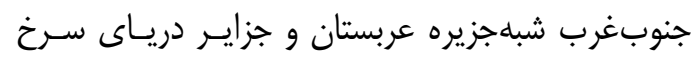
وجود دارد (Zarins 1989; Francavigla 1990). علاوه
توليد مى شوند، مى توانند منحنىهاى گززارش شـده توسـط

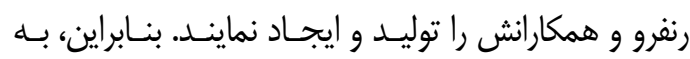

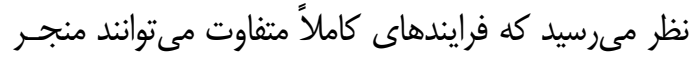

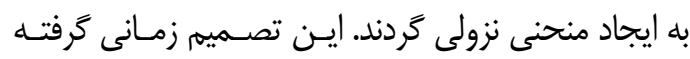

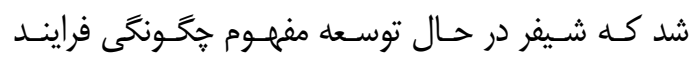

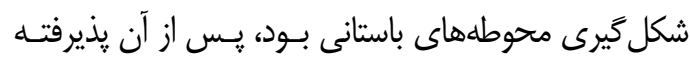

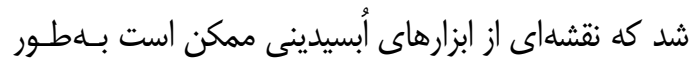

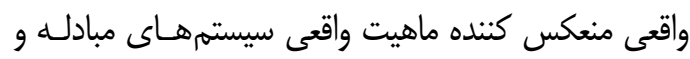

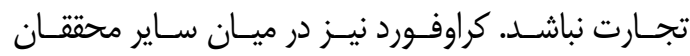

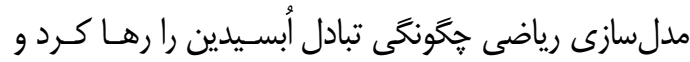

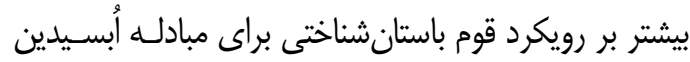
بين جوامع مختلف يرداخت (Crawford 1978). يزوهش هاى اخير كه توسط الرى فرام انجام يافتـه است كارهاى قبلى انجام شده توسط رنفرو و همكارانش

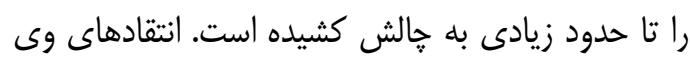
به كارهاى رنفرو و همكارانش اين است كه () نقشههاى

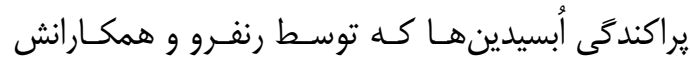

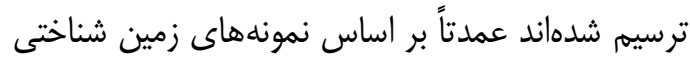

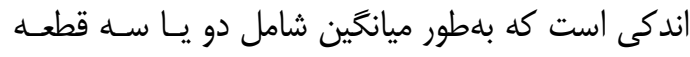

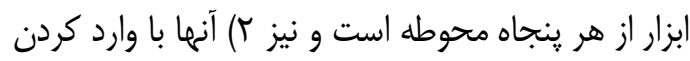

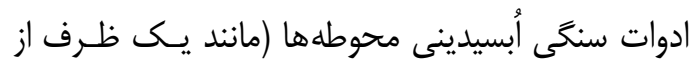

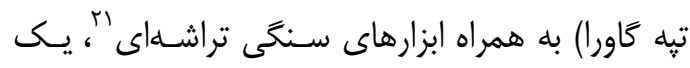

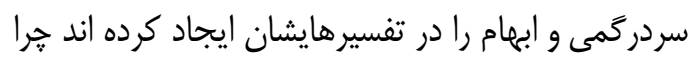

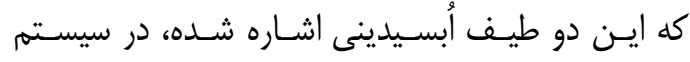

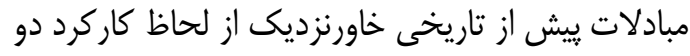

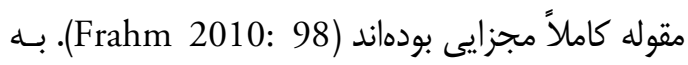

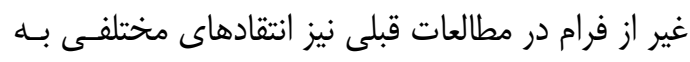
كارهاى انجام شده توسط رنفرو و همكارانش وارد شــده بود ) بright 1969; Wright and Gordus 1969) (Hodder and Orton 1976 ). نقد ديخرى كه فرام بر آن تأكيد داشت اين بود كه اغلب ابزارهاى آنـاليز شـده

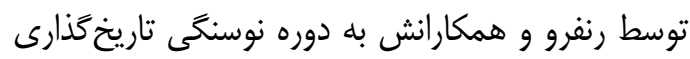

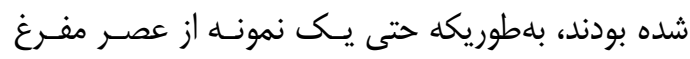

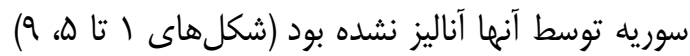

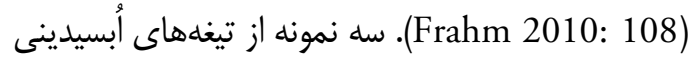

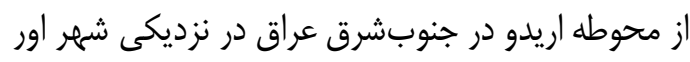

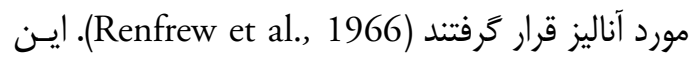




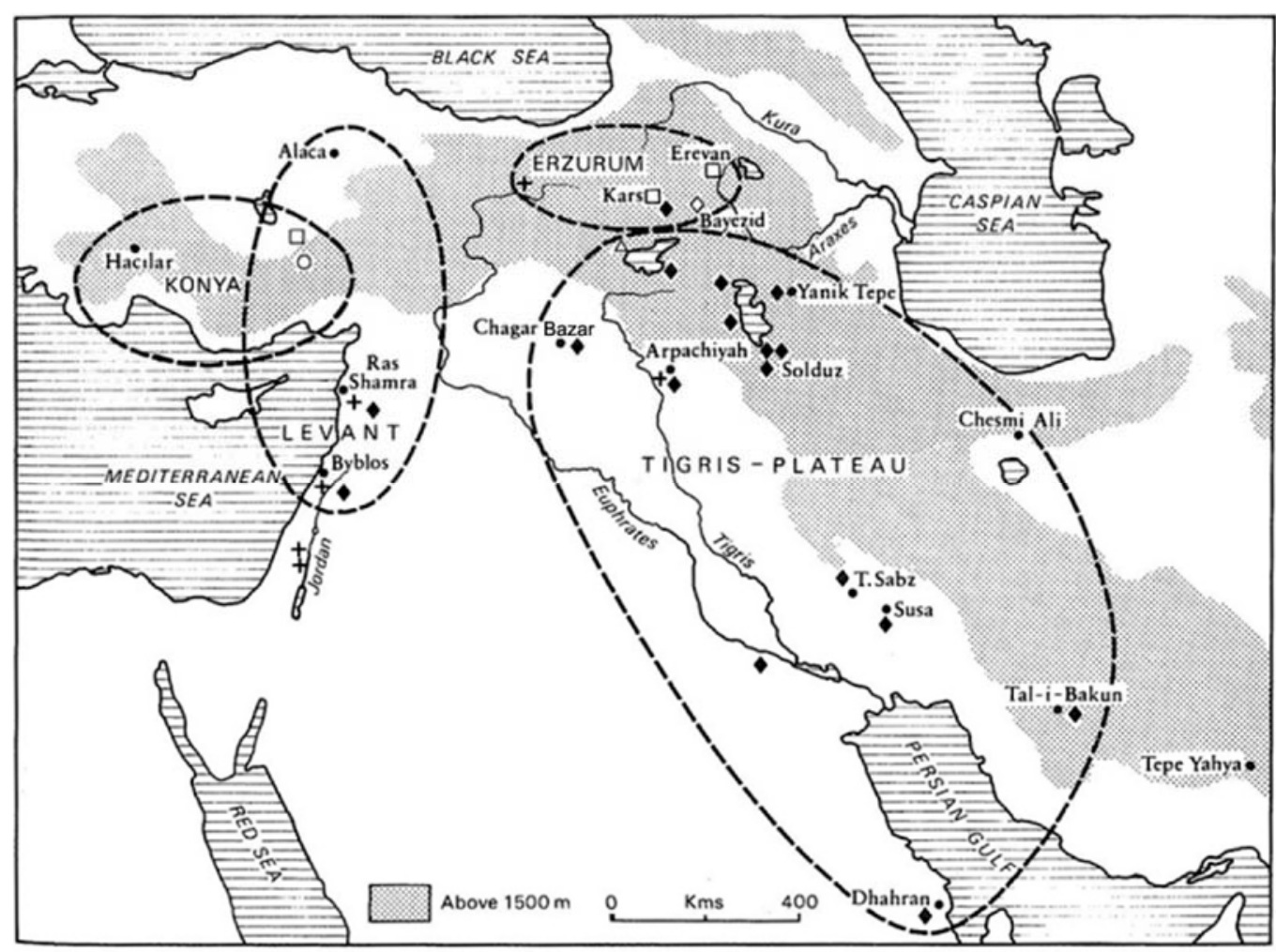

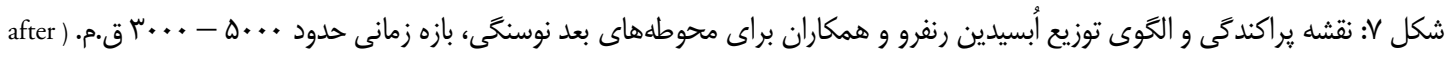
(Renfrew and Dixon 1976

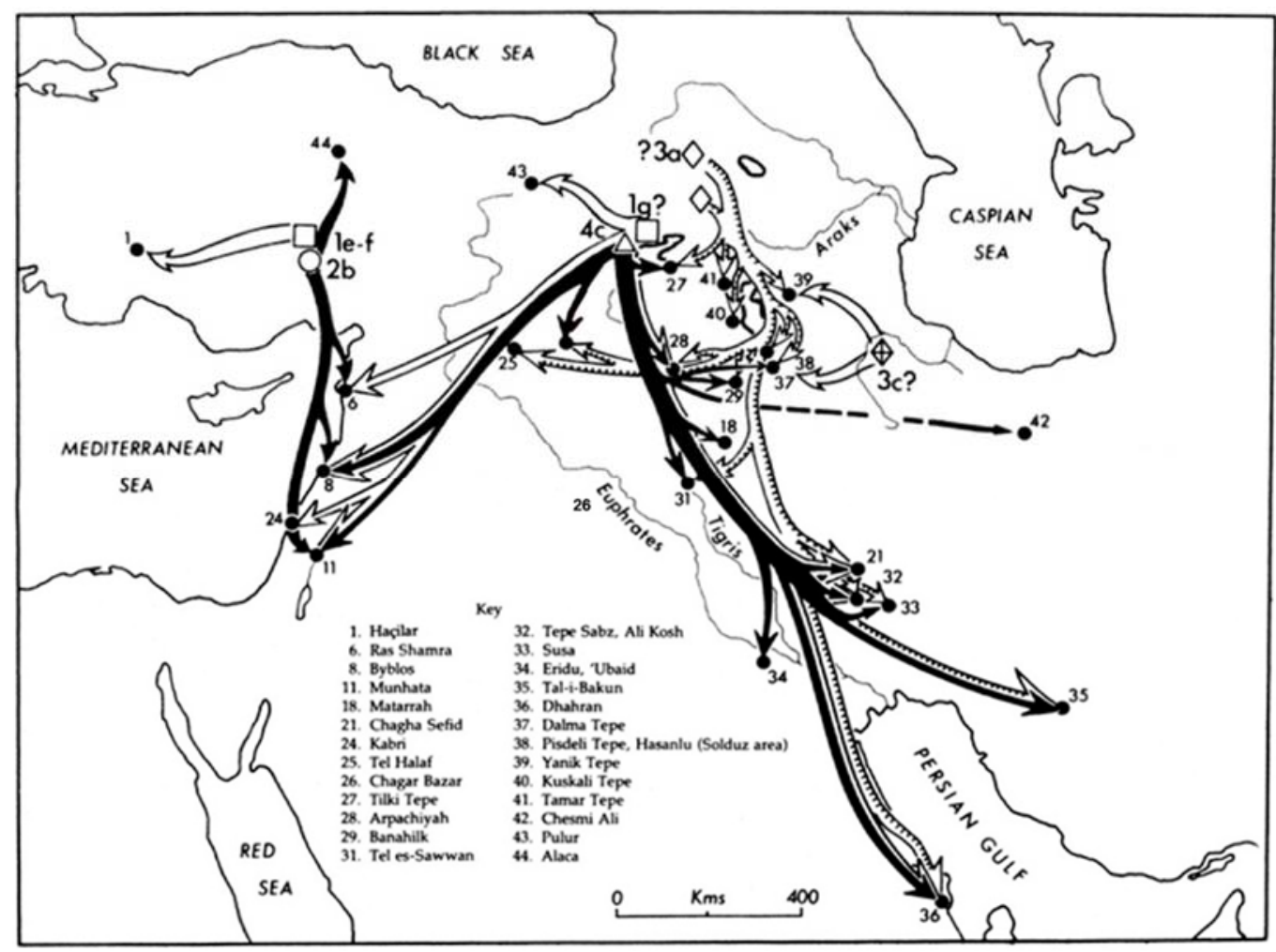

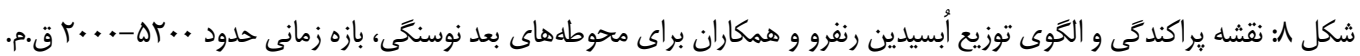
(after Dixon 1976) 


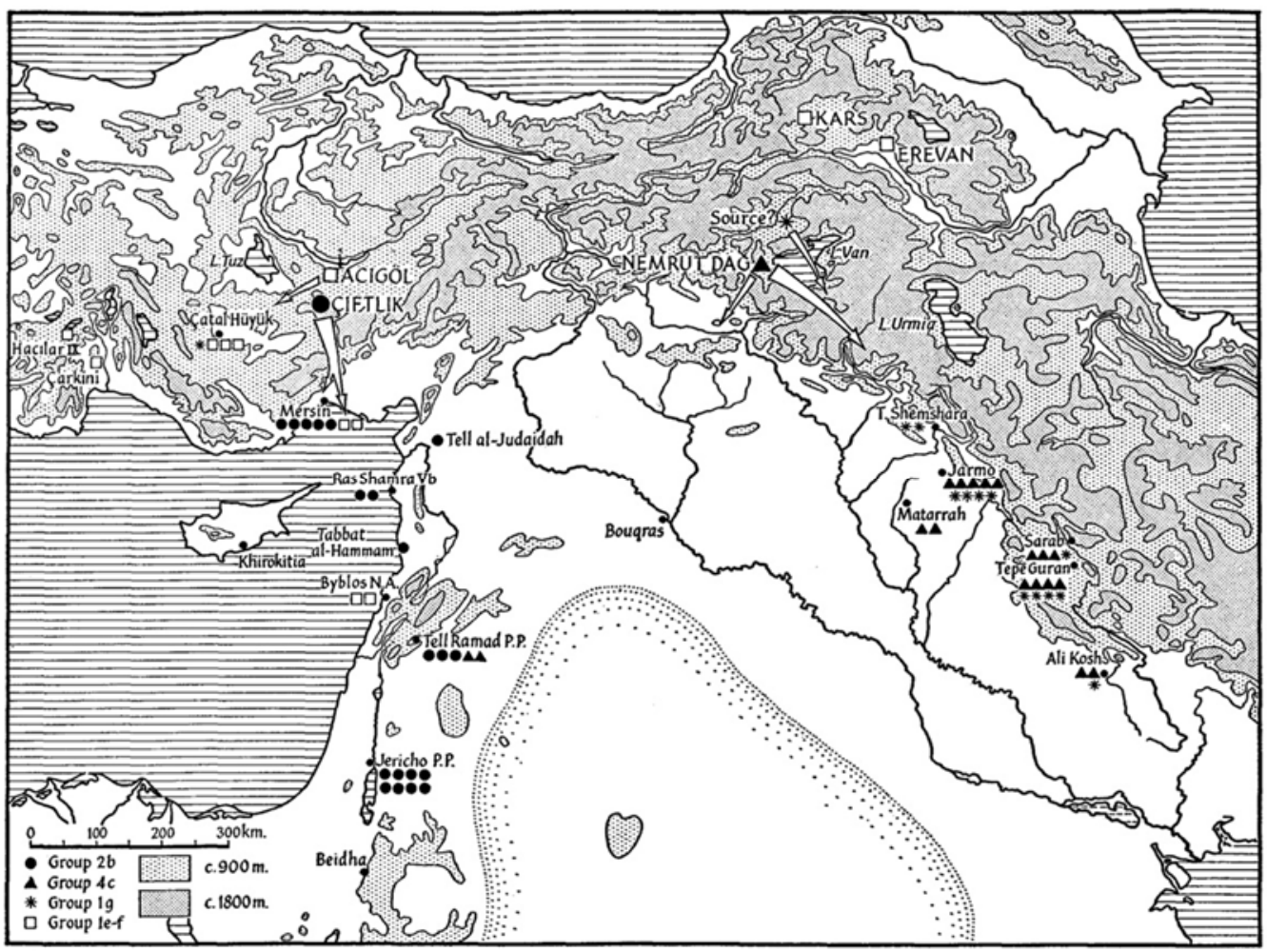

شكل ج: تجارت ابسيدين در خاورميانه در طى هزارهاى لو و وق.م. (معادن بهصورت/يتاليك مشخص شدهاند) (after Renfrew et al., 1966, Fig. 5)

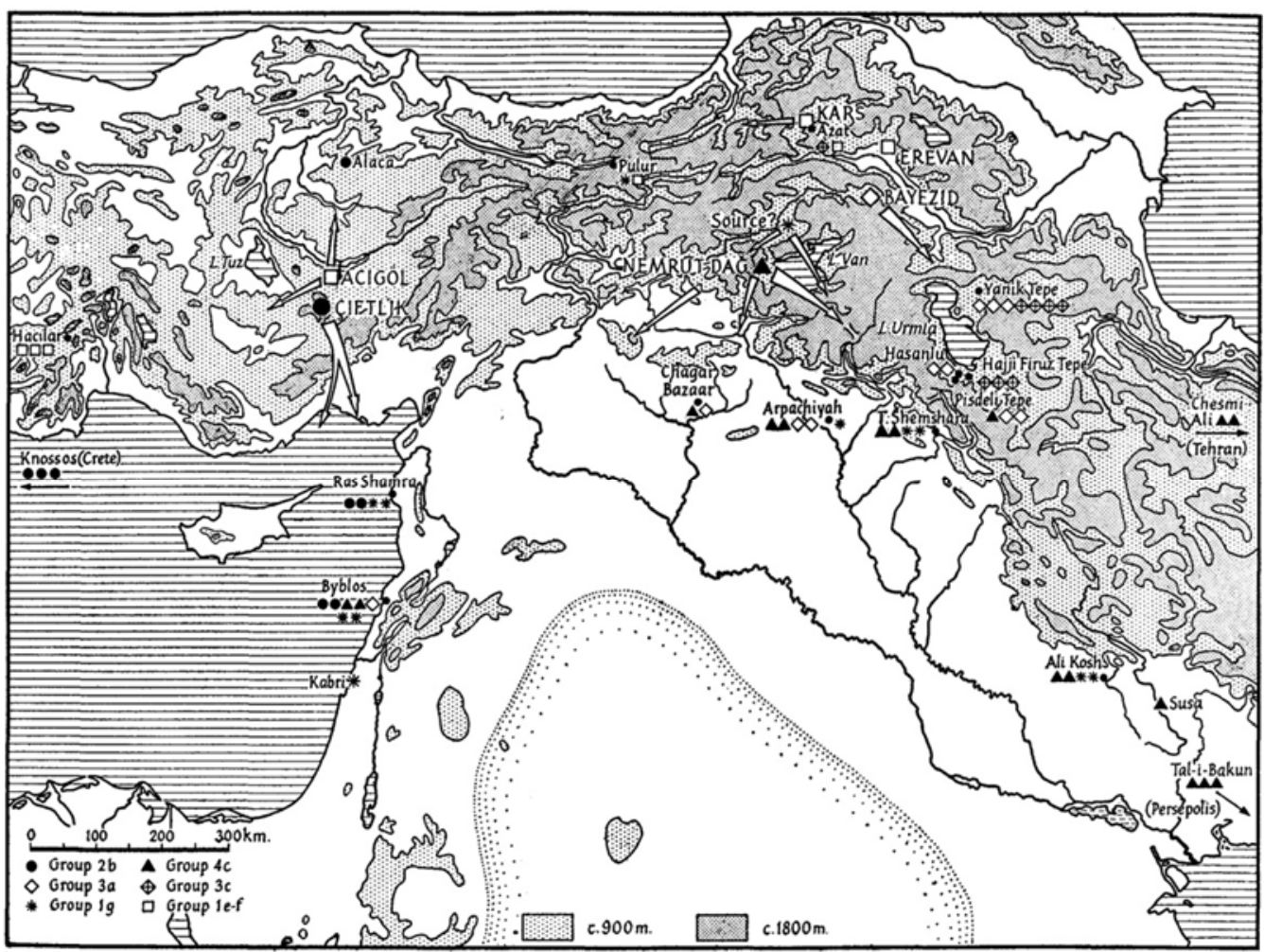

شكل • (ا: تجارت ابسيدين در خاور ميانه در طى هزاره هاى ه تا ب ق.م. (معادن بdصورت/يتاليك مشخص شدهاند) (after Renfrew et al., 1966, Fig. 6) 
استخراج شده است كه به احتمـال زيـاد ايـن نمونـهـهـا

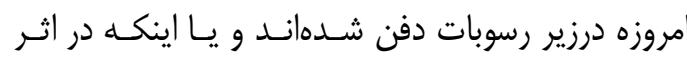

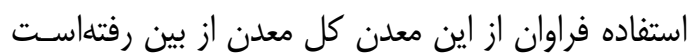

.(Bigazzi et al., 1998)

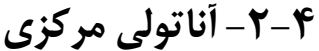

معادن أبسيدين آناتولى مركـزى (كايادوكيـه) عمــــاً در

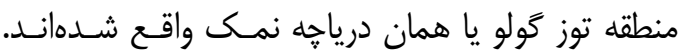
أبسيدينهاى اين منطقه عمدتاً از نوع كالى - منان - آلكـالين

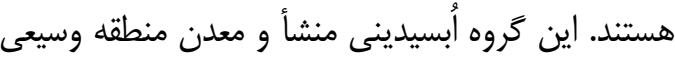

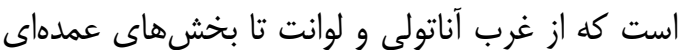

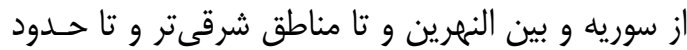
دشت دهلران در جنوبغرب ايران رانيز در بر مى مئيرد Renfrew et al., 1968; Wright 1969; ) 277-293 : Chataigner 1998)، امـا تـاكنون هـيجيج شواهدى علمى مبنى بر اينكه أبسيدينهاى اين منطقه تا

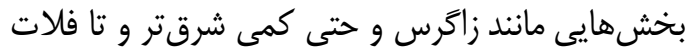
ايران رسيده باشد، وجود ندارد (Abdi 2004).

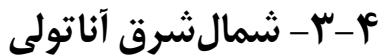

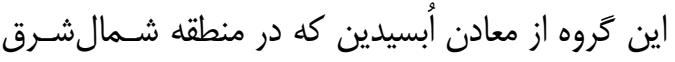

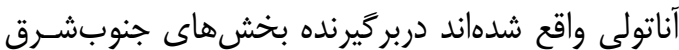
درياى سياه و مناطقى از شهر ارزينجان تـا كـوه آرارات است (134-Poidevin 1998: 125). تركيبات شيميايى نإن

$$
\text { اين معادن نيز كالى - آلكالين هستند. }
$$

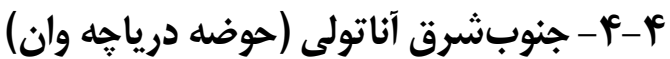

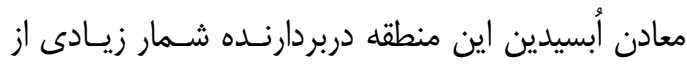
برونزدگى ها و ركهها در اطراف درياجه وان است كه تا قسمتهاى شرقى آن و تا حوضه درياجه اروميه امتـداد يافته است ) Wright 1969; Wright and Gordus 1969; Dixon 1976; Renfrew and Dixon 1977; Poidevin 1998: 135-150). معادن اين منطقه از هر : مر دو كونه يرآلكالين و كالى آلكالين هستند.

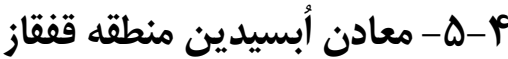

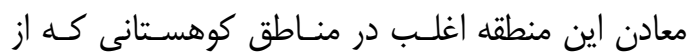
شمال غرب تا جنوبشرق درياجه سـوان در ارمنسـتان و
بر مناطق اشارهشده احتمال مىرود كه معادن أبسـيدين

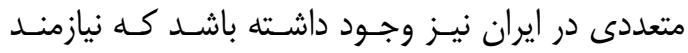

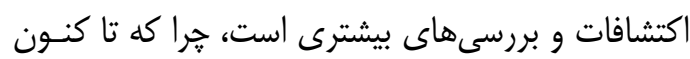
معدن شاخصى كه مرتبط با استخراج دوره باستان باشد الشد

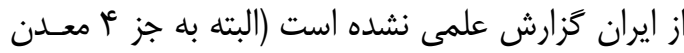
شناسايى شده اخير توسط نيكنامى و همكاران). امـا در يك تقسيمبندى كلى معادن موجود در آناتولى و قفقاز به

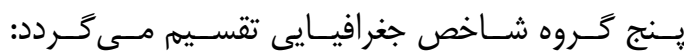

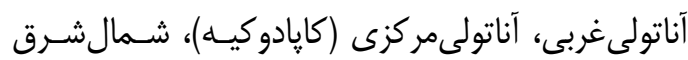

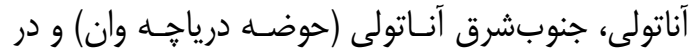

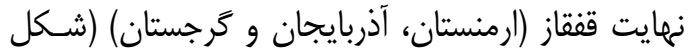
.(Poidevin 1998; Chataigner et al., 1998)(1) در زير هر يك از ينج گروه به اجمال شح داده مى شود:

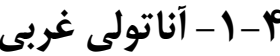

قسمتهاى مركزى و غربى آنـاتولى داراى يكسـرى از

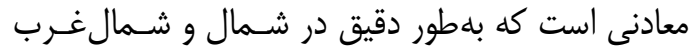

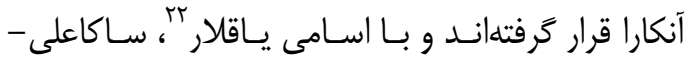

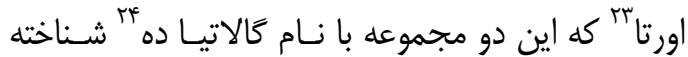

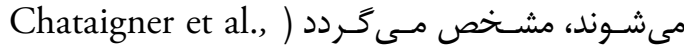

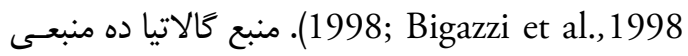
نيست كه از لحاظ كســته مكـانى آن شـناخته شـده و معروف باشد بلكه استفادهاى عجيب و غريب از آن در

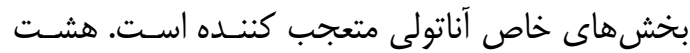

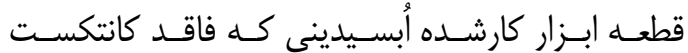

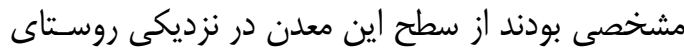

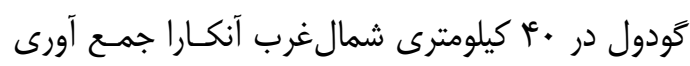

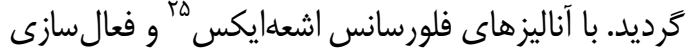

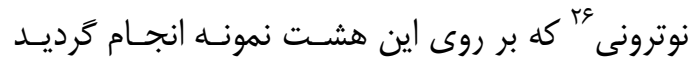

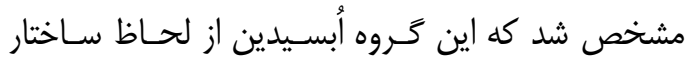

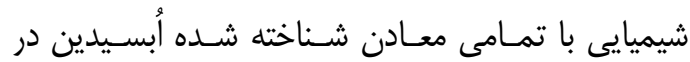

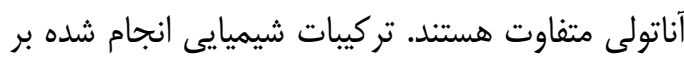

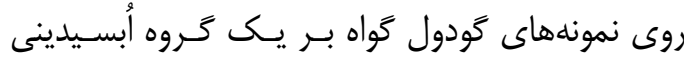
همسانى بود كه اين كروه كالاتيا ده را بلططور آشكارى از

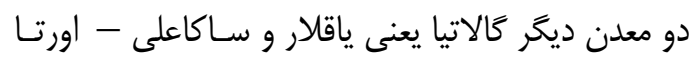
متمايز مىساخت (Keller et al., 1994). معدن كالاتيا ده به احتمال زياد از مجموعه معلن آتشفشانى كـالاتين 
قطعه را آشكار ساخت. از محوطه جِياسـبز كـه بــه دوره

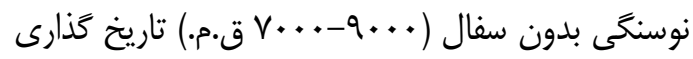

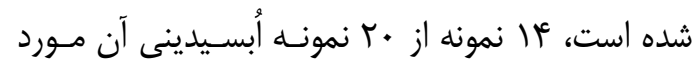

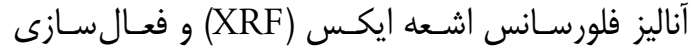

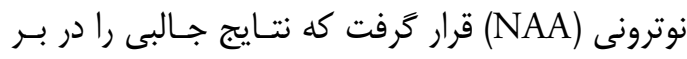

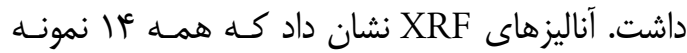

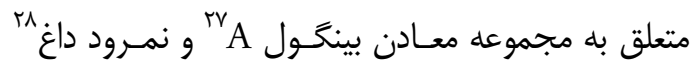
شمارههاى r-9 هستند. اما آناليز دقيقتر نمونهها توسط

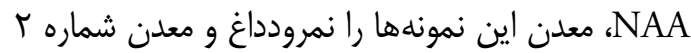
تعيين نمود (Darabi and Glascock 2013). از ديخر محوطههاى شاخص دوره نوسنگى بلدون

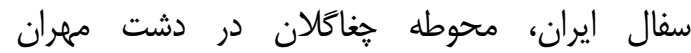

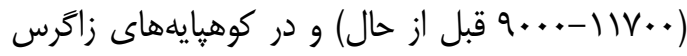

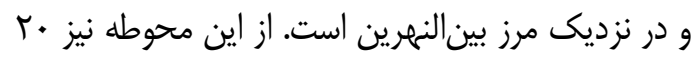

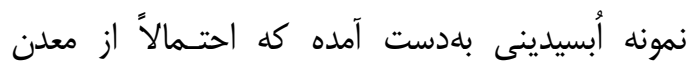

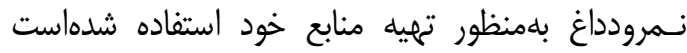
.(Zeidi and Conard 2013) أبسيدينهاى بهدست آمده از منطقه زاكرسمركزى در اغلب محوطههاى نوسنگى اين دوره كزارش شدهاند كه عمده اين محوطهها شامل كوران و جِيـاجنى (اواخـر

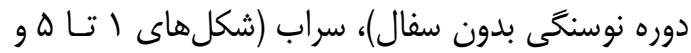

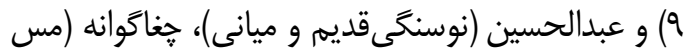

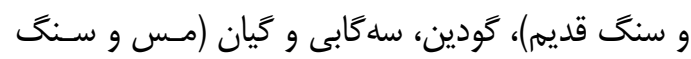

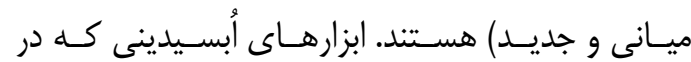
بخشهاى غربى و جنوب غرب ايران يافته شدهاند اغلب

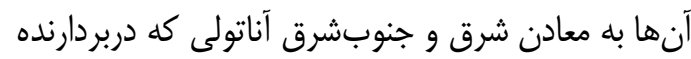
مناطق بينگول و حوضه درياجه وان است (بـراى مثال

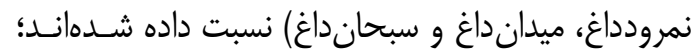
موضوعى كه در مورد محوطه جياسبز نيز با قطعيـت بـهـ اثبـات رسـيد ( Glascock 2013 Darabi and). در محوطه سه كابى منشأ ابزارهاى أبسيدينى معادن نمـرود داغ در شمال درياجه وان و دو معـدن در منطقـهـ قفقـاز معرفى شدهاند (Abdi 2004). در محوطه جغاگوانه تنها دراجها

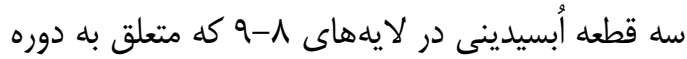

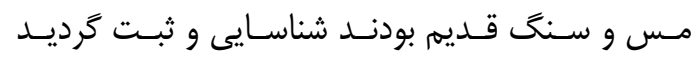

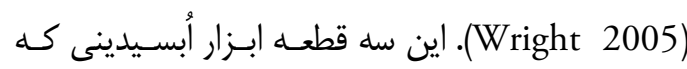
داراى رنخ سياه مات تا كمى شفاف بودند بـه احتمـال
آذربايجان كشيده شدهاند، شكل كرفتتهاست، امـا معـادن مجزايى نيز در كرجستان و شمال قفقاز و در امتـداد رود باكسان در سمت روسى كوههاى قفقاز شناسايى شدهاند.

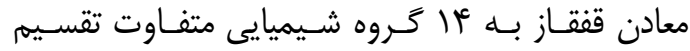

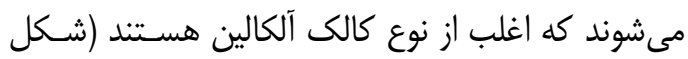
.(Blackman et al., 1998) (1)

\section{ه- يافتهها و ابزارهـاى أبسـيدينى و معـادن احتمالى موجود در ايران}

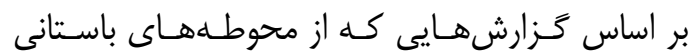

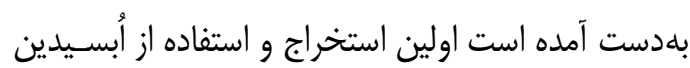

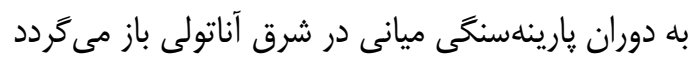

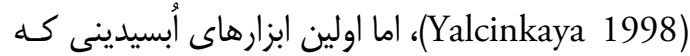
در بافت لايههاى باستان شناختى ظاهر مى گردند متعلق

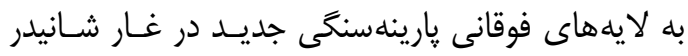

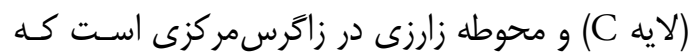

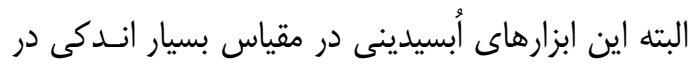

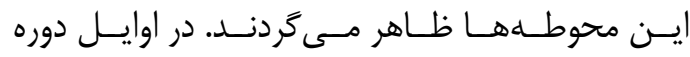

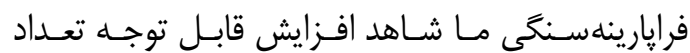

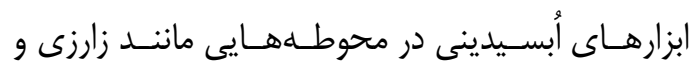

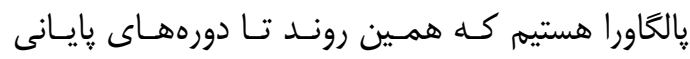

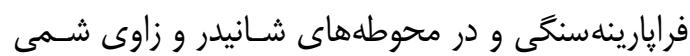

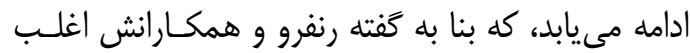

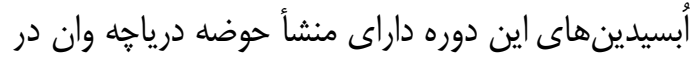
شرق آناتولى هستند (Renfrew et al., 1968). در طى دوران نوسنكى بدون سفال، ما شاهد يـك

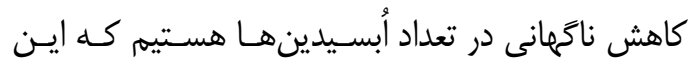

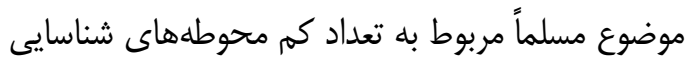

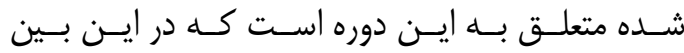

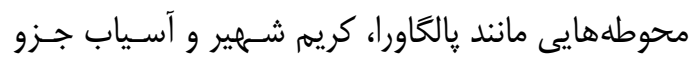

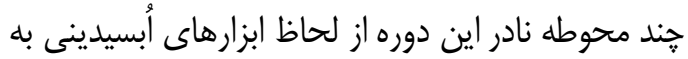
حساب مى آيند (Abdi 2004). اما كاوشهاى اخيرى كه دها

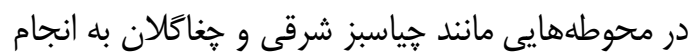

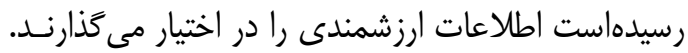
محوطه جياسبز شرقى كه در زاكرس در غرب ايران و در إنا

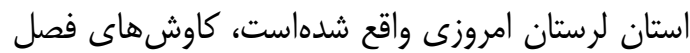

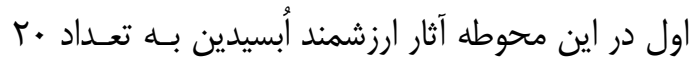



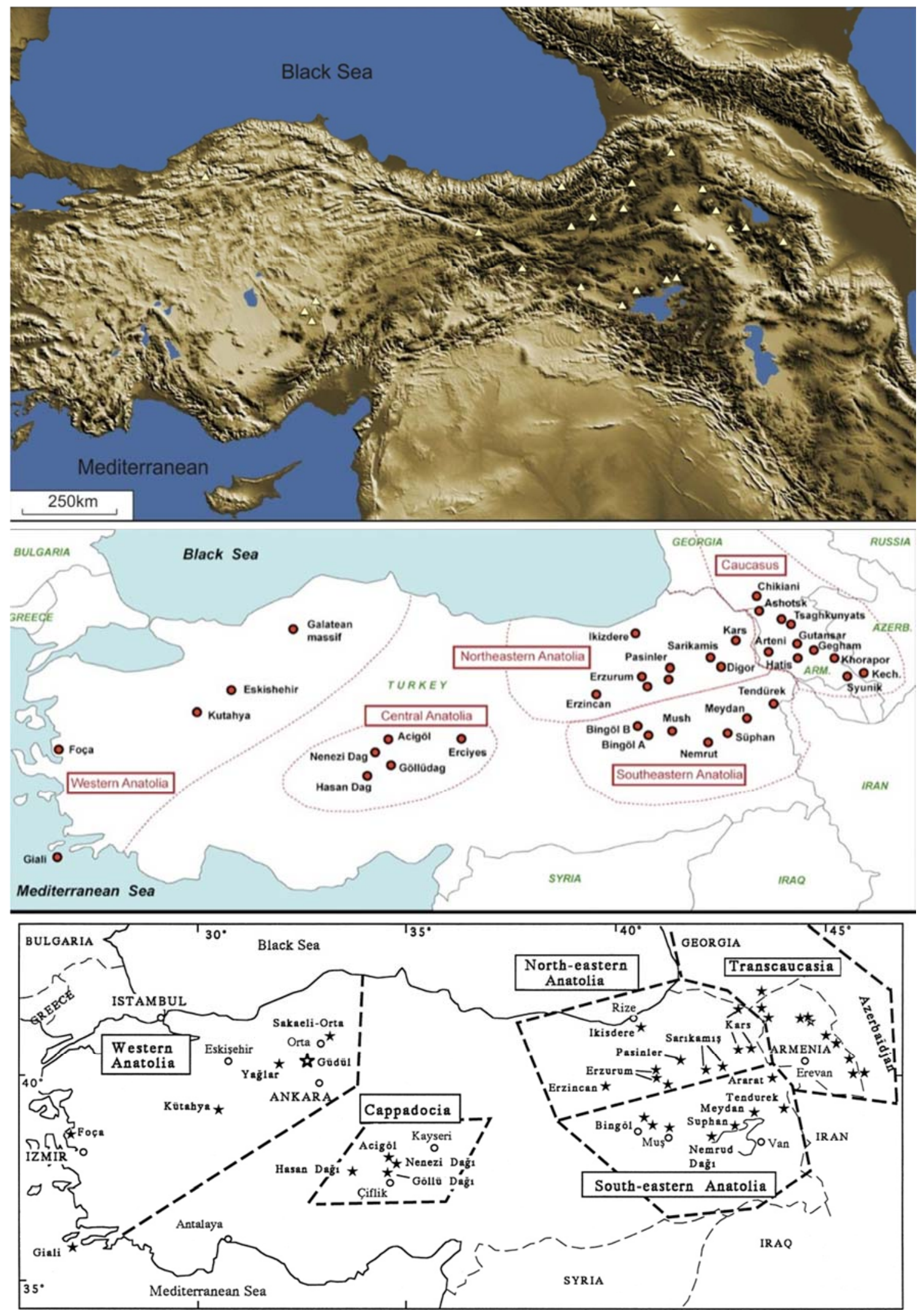

شكل (ا: معادن شناخته شده أبسيدين در آناتولى و قفقاز (ستارهاى مشكى رنك) - بينج منطقه أبسيدينى شناخته شده در حوزه آناتولى و قفقاز (after Chataigner et al., 1998, Fig. 1) 
آناليزهاى رونفرو اغلـب أبسـيدينهـاى دهلـران از معـادن

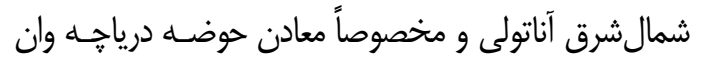

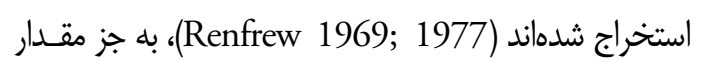

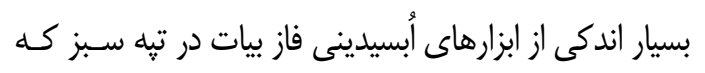

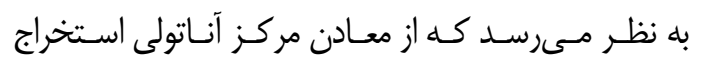

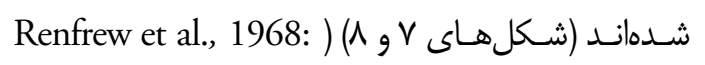
.(325; Chataigner 1998: 292, Figs 7a-b

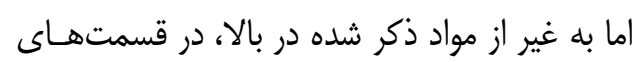
جنوبشرقى اين منطقه ابزارهاى أبسـيدينى مختلفـى از

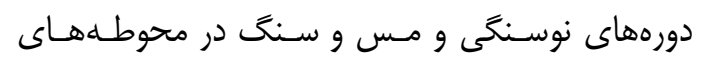

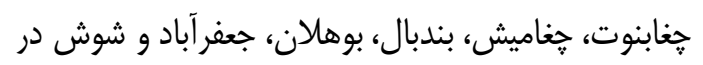

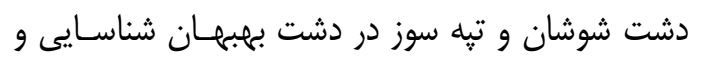

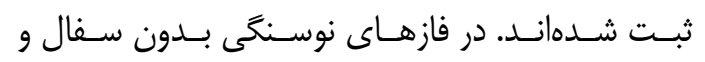

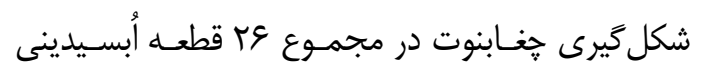

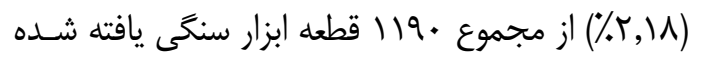

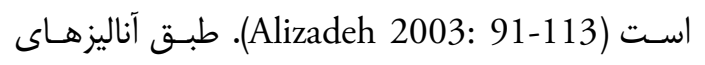
بلكمن أبسيدينهاى محوطه جزاميش از معادن اطـراف درياجه وان استخراج شدهاند (Blackman 1984: 36).

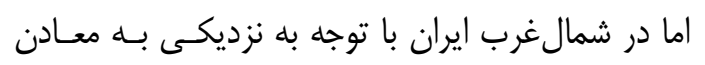

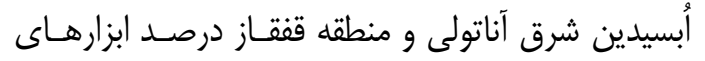

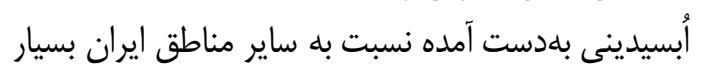

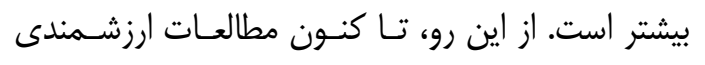

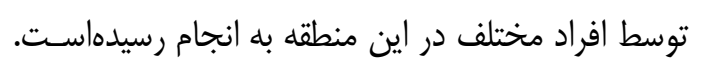
ابزارهاى أبسيدينى اين منطقه، از دوره نوسنگى ميانى در إنى

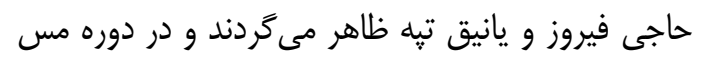

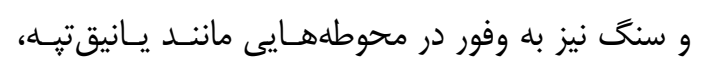

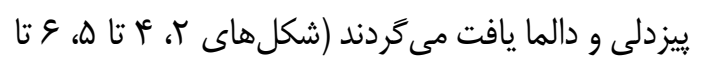

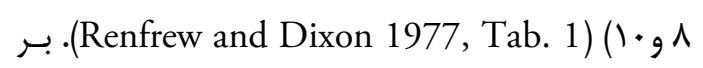
خلاف محوطههاى نوسنكى زاكرس و جنوبغرب ايران

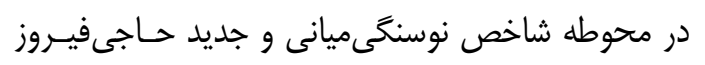

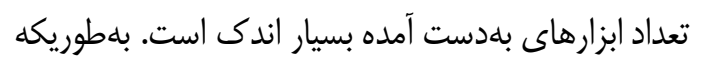

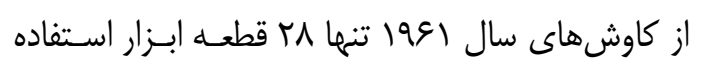

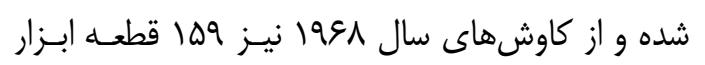

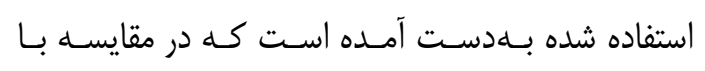

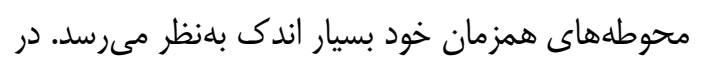

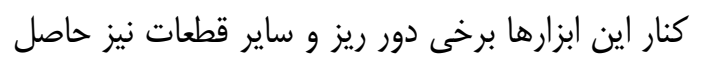

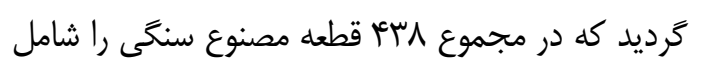

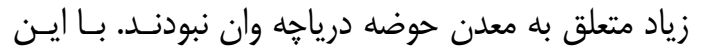

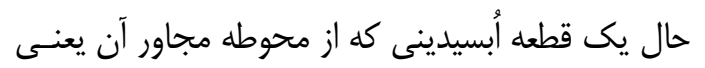
توهخوشكه (كه متعلق به اواخر دوره مس و سنى إنى ميانى)

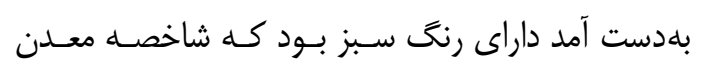

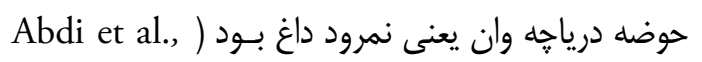

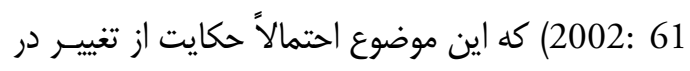

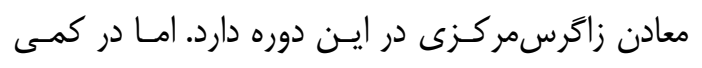

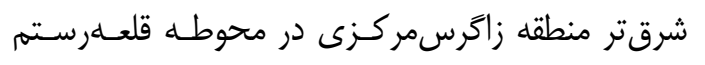

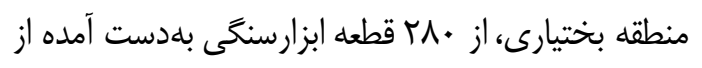

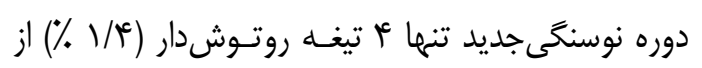

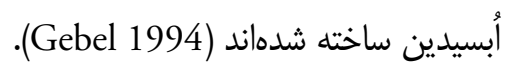

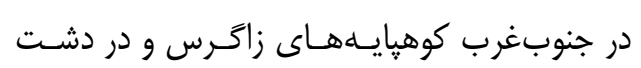
دهلران، ابزارهاى أبسيدينى از دوره اواخر نوسنگى بلدون

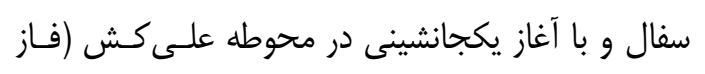

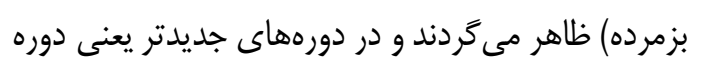

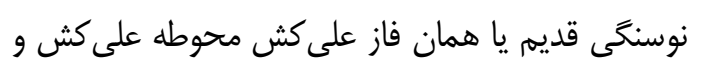

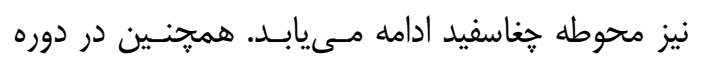

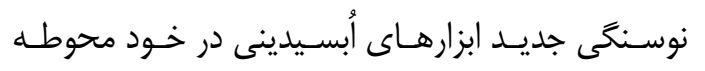

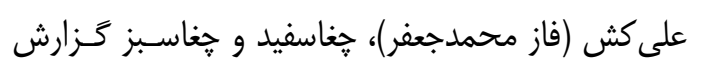

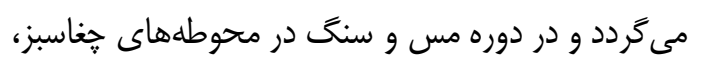

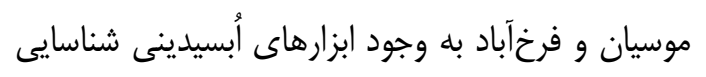
و ثبت مى گردد (Renfrew 1969; 1977).

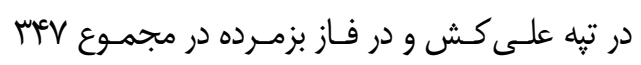

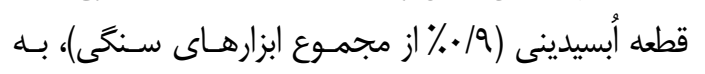

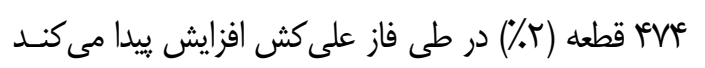

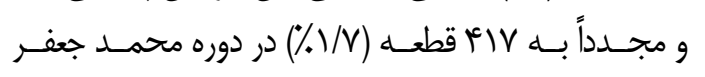

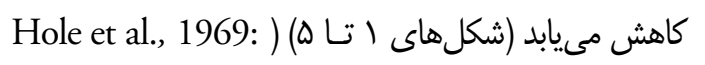

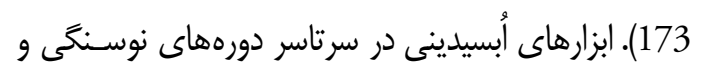

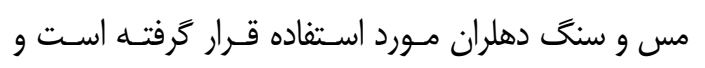

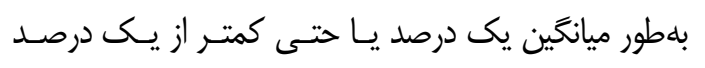

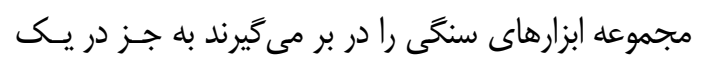

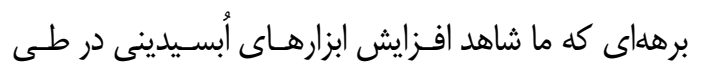

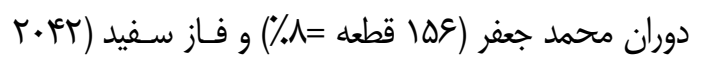

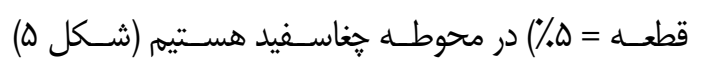
(Hole 1977, Tab. 38; Renfrew 1977)

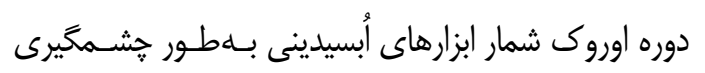
رو به كاهش مى كذارند (Wright 1981:275). بـر طبـق ارئق

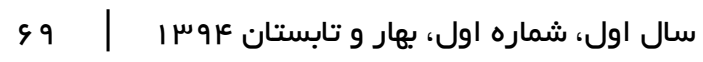


(1976: Table 1-2; Voigt 1988 ). از آنجايى كه ايـن

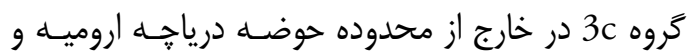
آذربايجان ايران گزارش نشده است، رنفرو و همكارانش اينكَونه استباط مى كنند كه المعلن 3c

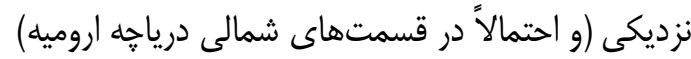

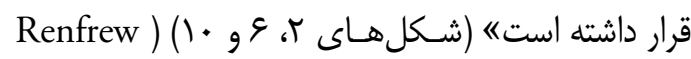
كامش : and Dixon 1976: 145 كاوشهاى انجام ترفته در لايههاى نوسنكى يانيقتيـه

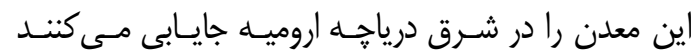

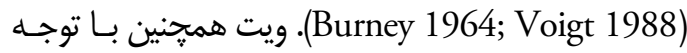

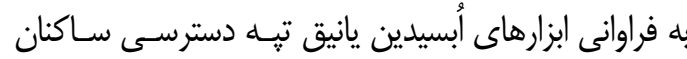

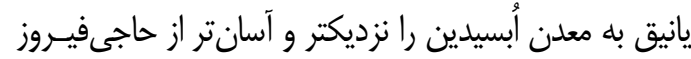

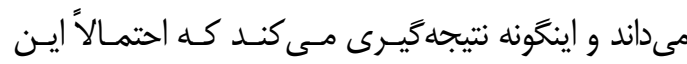

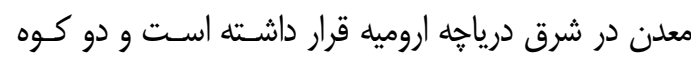

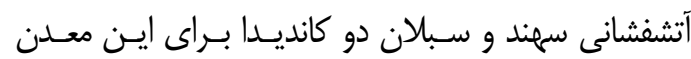

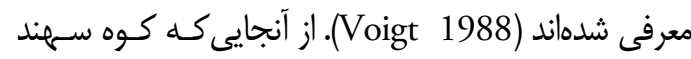

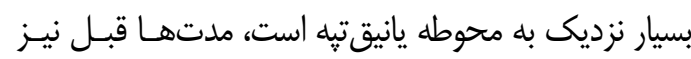

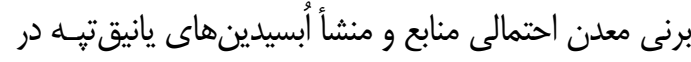

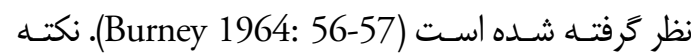
قابل توجه در مورد أبسيدينهاى يانيق اين است كه عـانلاوه

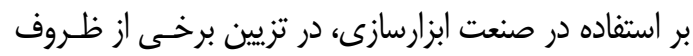

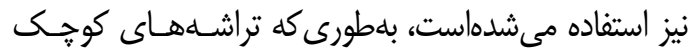

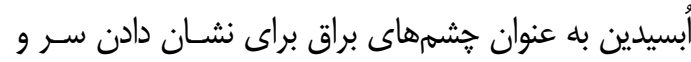

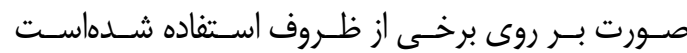

.(Burney 1962: 138, Plate 43, Figure 12) به جز محوطهاى يانيقتبه و حاجى فيروز، سه نمونه

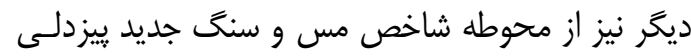
مورد آناليز قرار كرفتند و نتيجه حاصـل از آن آن نشـان داد داد

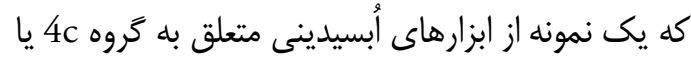

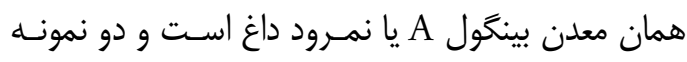

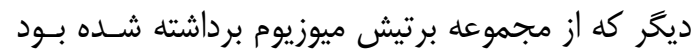

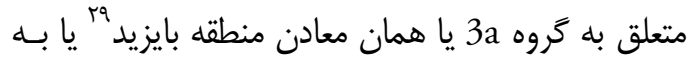

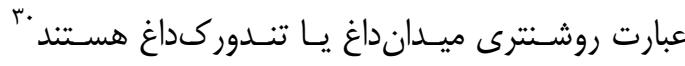

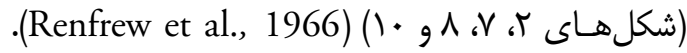
رنفرو و همكارانش يك نمونه از عصر مفرغ تبه حسنلو را

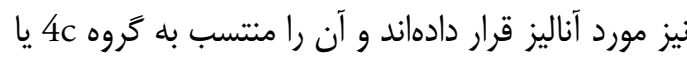

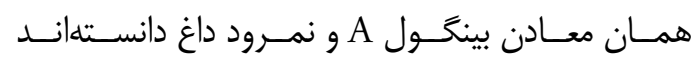

مى كرديد كه از ميان آنها عسب قطعه از جنس أبسيدين

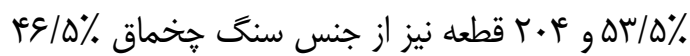

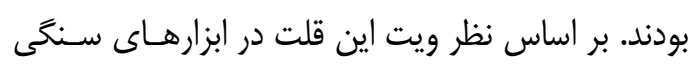

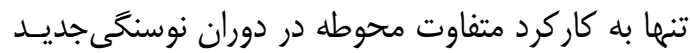
بستخى دارد (Voigt 1988: 218-221). بر اساس آناليز

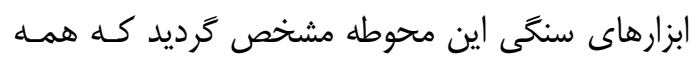

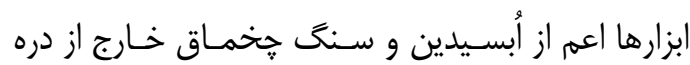

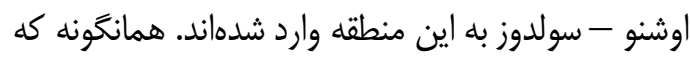

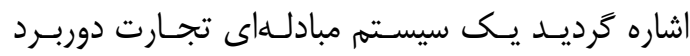

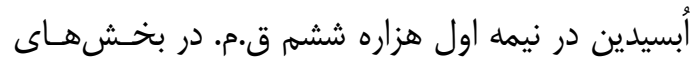

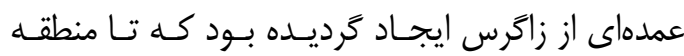

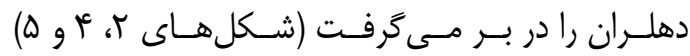
1969a; 1977b;Renfrew and Dixon Renfrew ) (1976; Wright 1969 ). محوطه حاجى فيـروز نيـز در

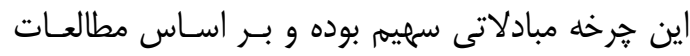

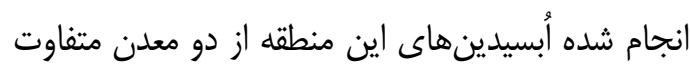

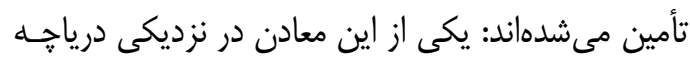

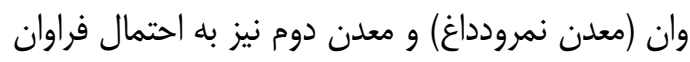
در نزديكى حوضه درياجه اروميه بودهاست. نكتـه قابـل نمانل

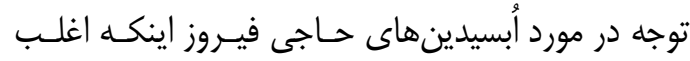

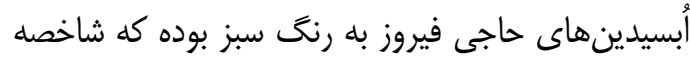

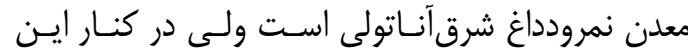

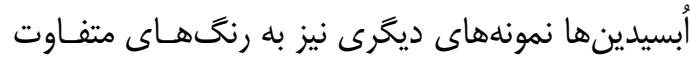

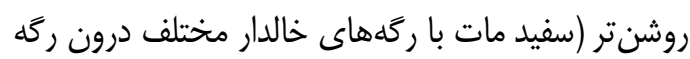

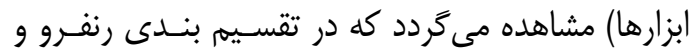

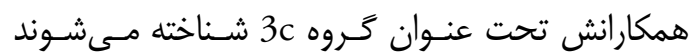
.(Renfrew et al., 1966: 40, Table II) اما در زمان مطالعه أبسيدينهاى منطقه شمال غرب

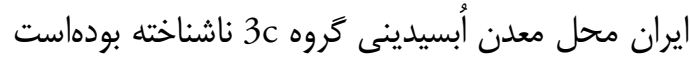

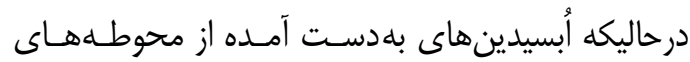

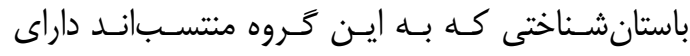

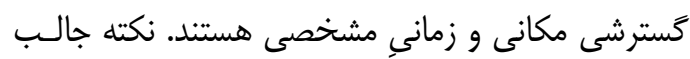

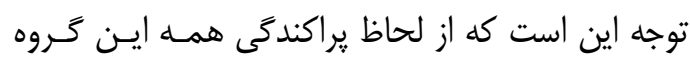

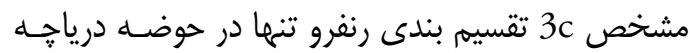

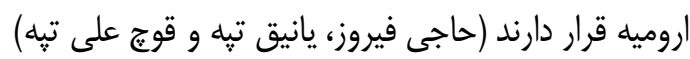

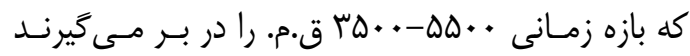

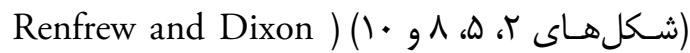

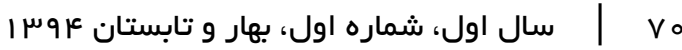


نمونههاى آناتولى و قفقاز همخوانى ندارند، و نويسندكان

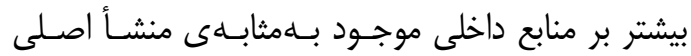

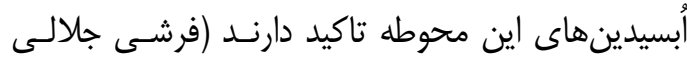
Agha-Aligol

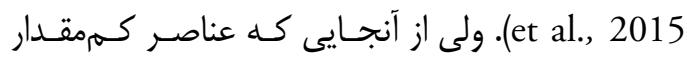

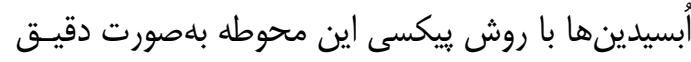

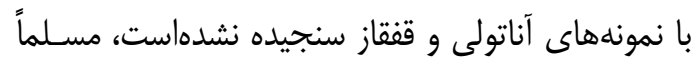

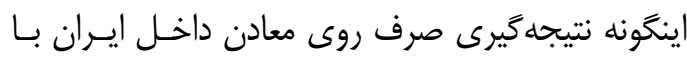

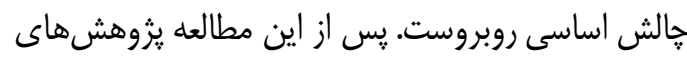

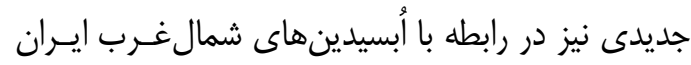

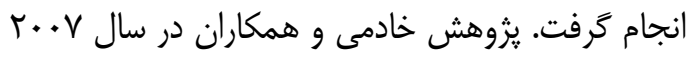
نيز با رويكرد جستجوى معادن محلـى أبسـيدين ايـران،

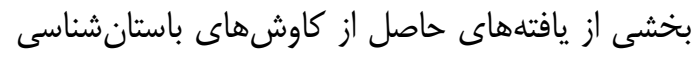

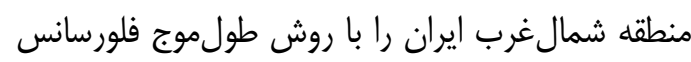

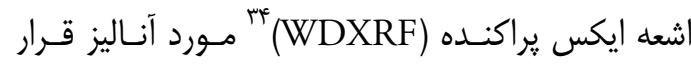

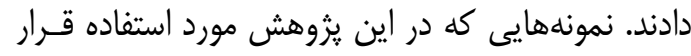

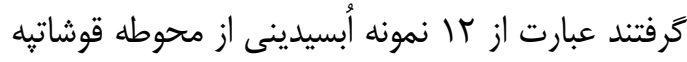

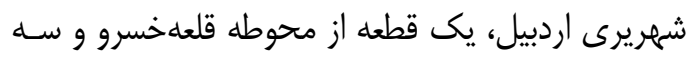

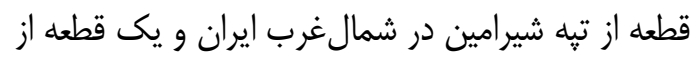

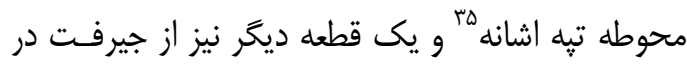

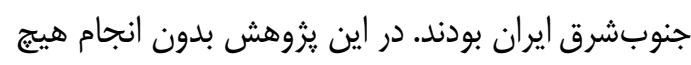

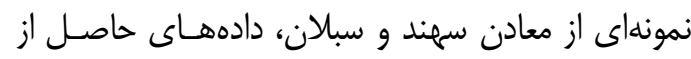

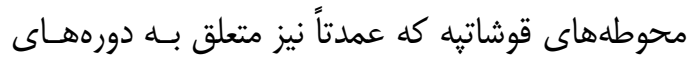

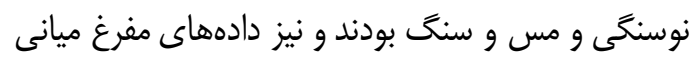
قلعه خسرو با توجه به نزديكى به كوه آتشفشانى سبلان

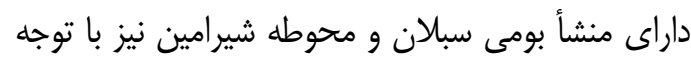

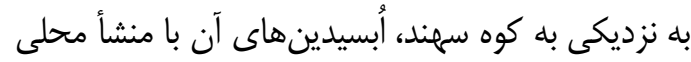

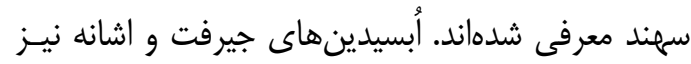

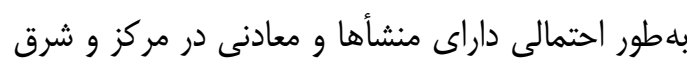

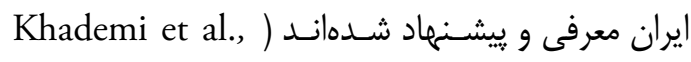
2007). ولى جيزى كه مسلهم است، بلهدليل نبود دادههاى

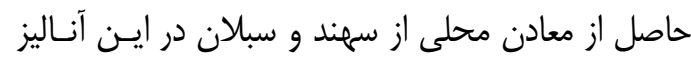

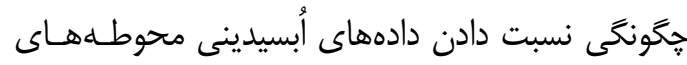

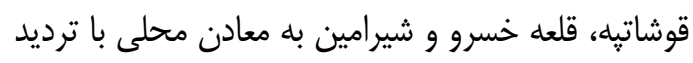
اساسى روبروست.

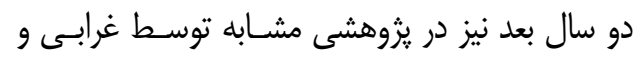

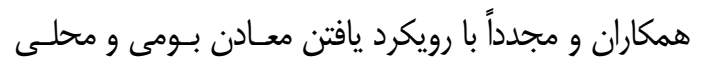

و و هند سال بعد نيز مهدوى و (Renfrew et al., 1966)

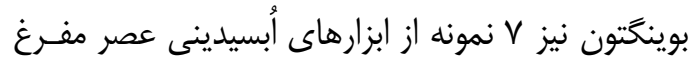

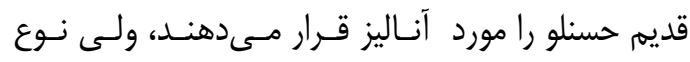
تحليل هاى آنها تا حدود زيادى مبهم است. آنها تنها ينج

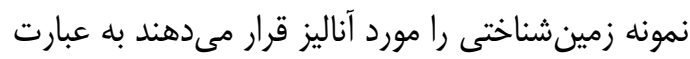
ديخر از هر ينج نمونه معدن آناتولى يكى نمونه انتخ انتخـاب

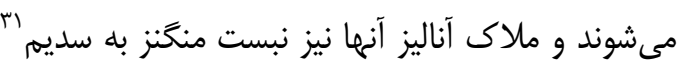

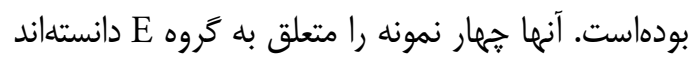

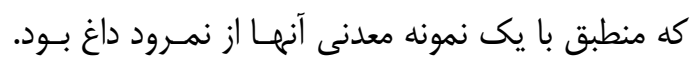

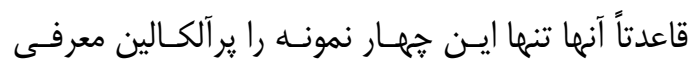

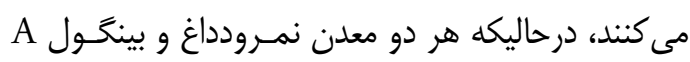

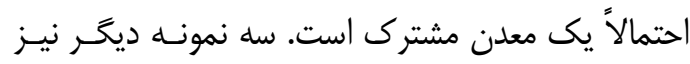

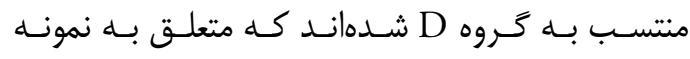

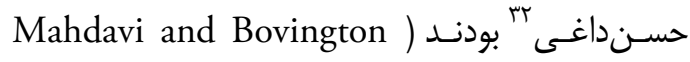
1972). منشأيابى نمونههاى گروه D و نسبت دادئ (

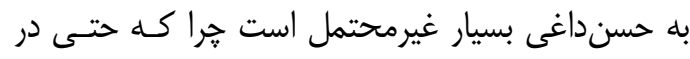

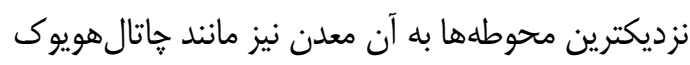

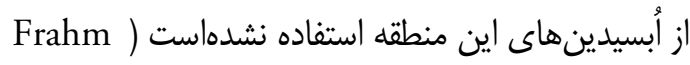
601

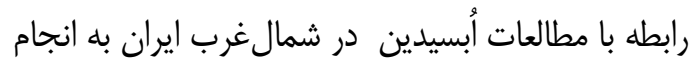

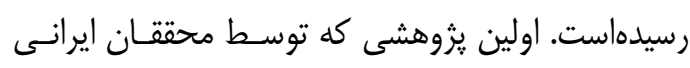

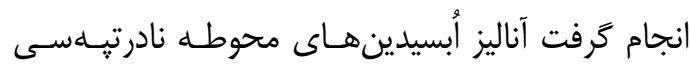

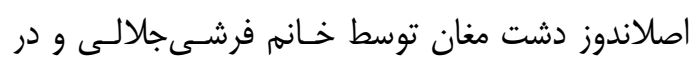

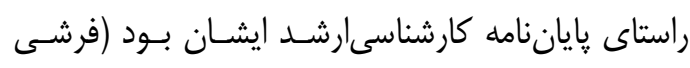

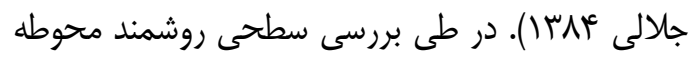

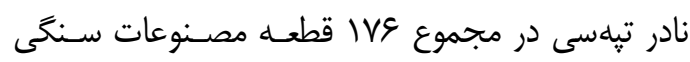
بهدست آمد كه.

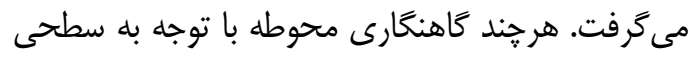

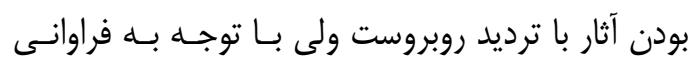

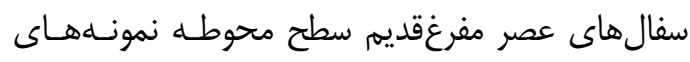

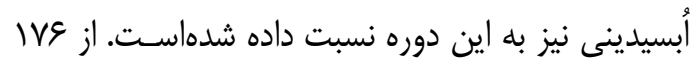

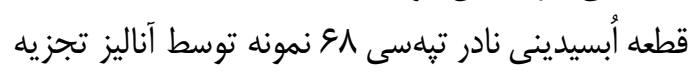

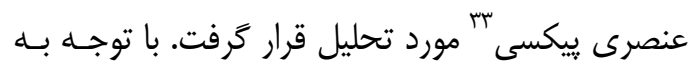

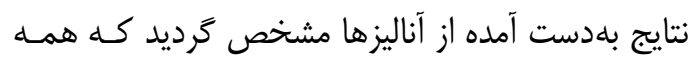

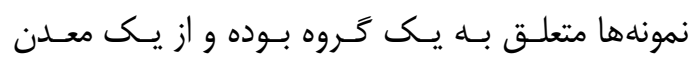

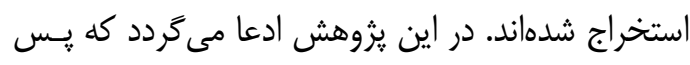

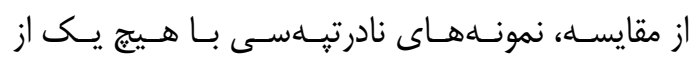


معادن بومى و محلى، در همان منطقة اطـراف محوطــهـ

جغابن قرار داشتهاست (Khademi et al., 2010).

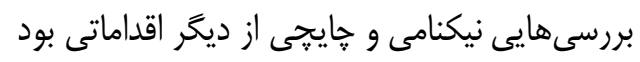

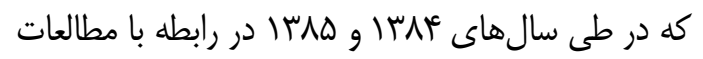

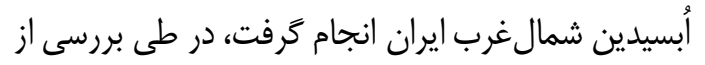

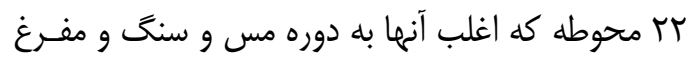

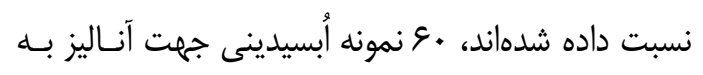

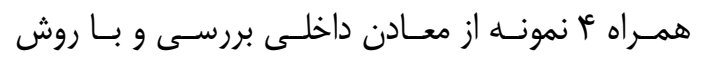
WDXRF

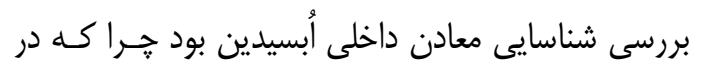

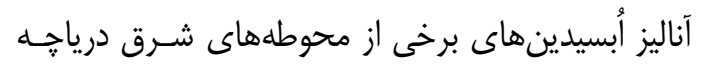

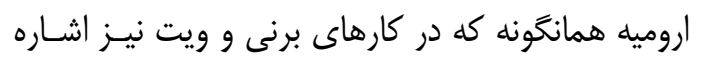

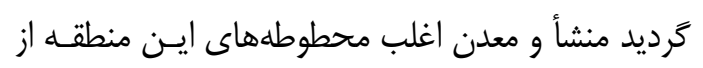

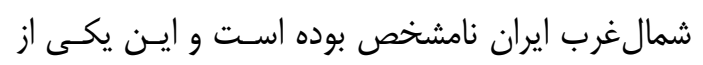

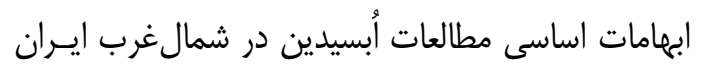

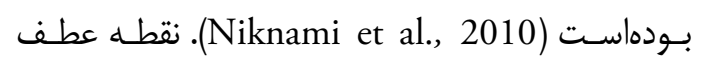
مطالعات نيكنامى و هايجى در اين بـود كـه اولـين بـار

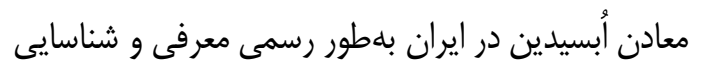

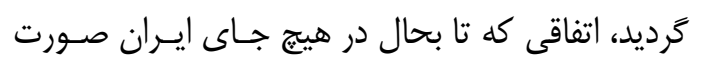

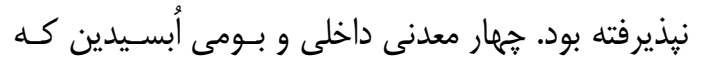

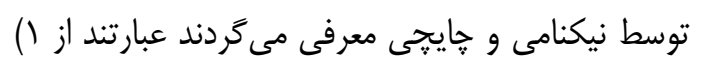

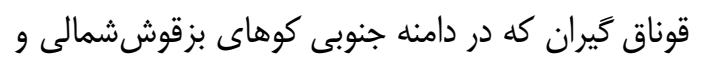

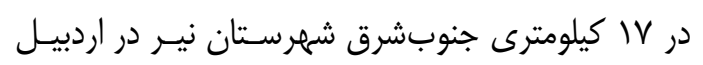

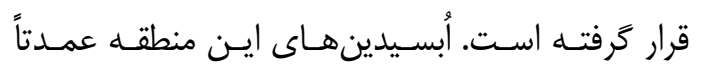

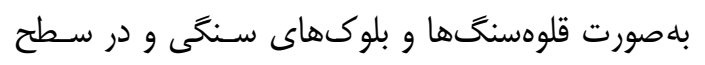

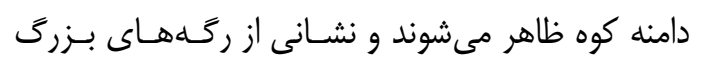

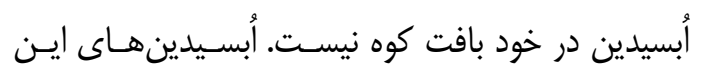

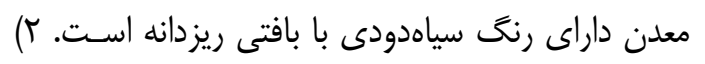

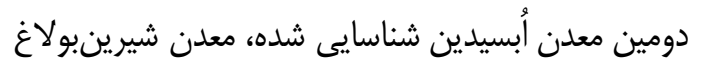

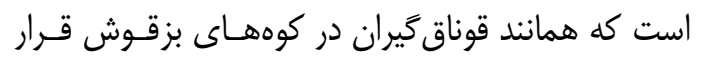

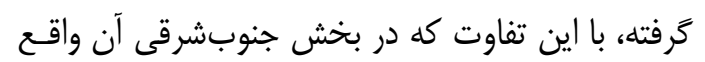
شده است. معلن أبسيدين اين منطقه شامل يك ساخت دنار

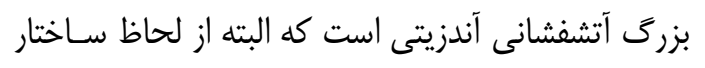

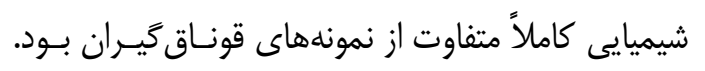

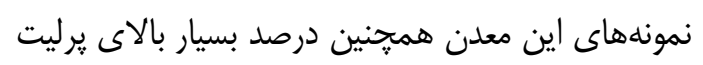

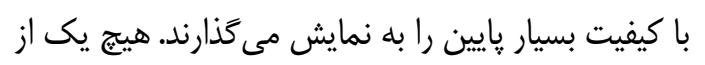

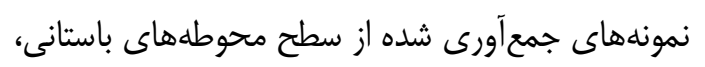

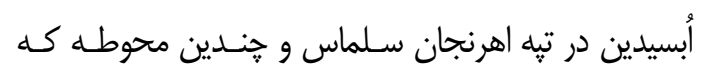

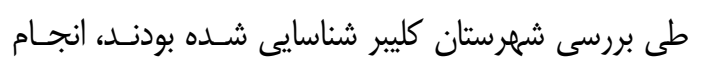

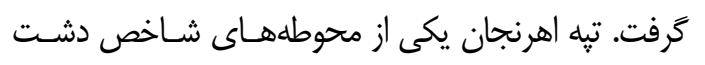

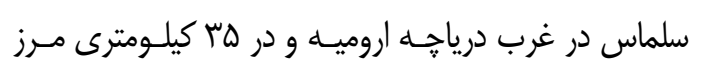

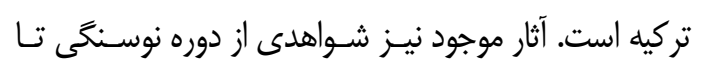

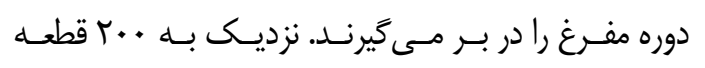

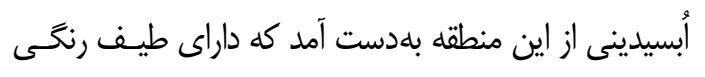

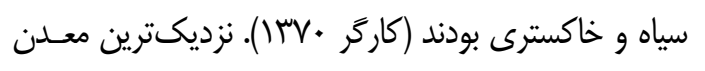

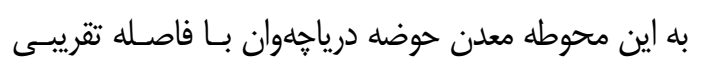

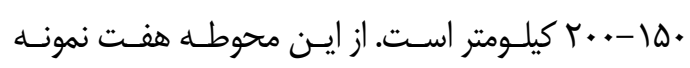

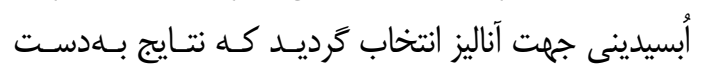

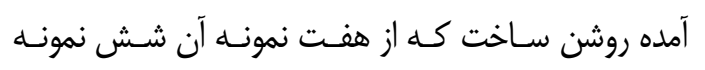

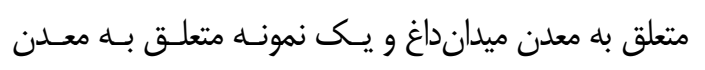

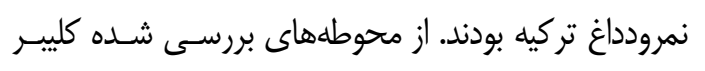

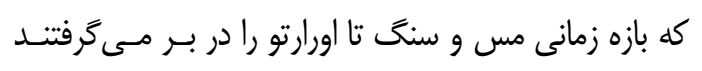

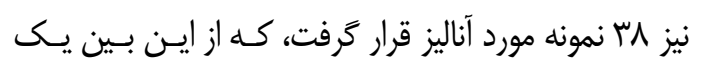

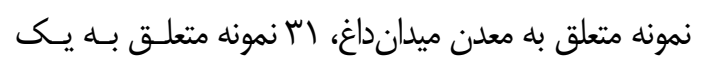

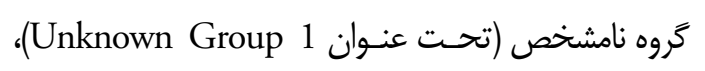

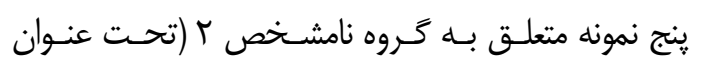

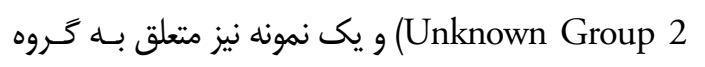

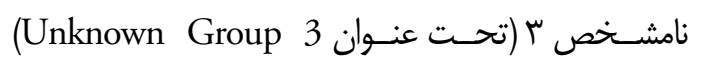

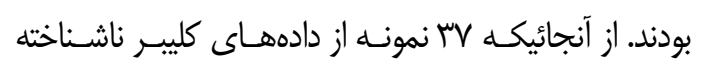

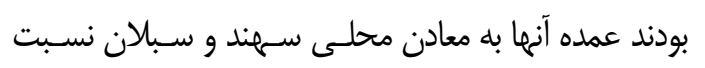

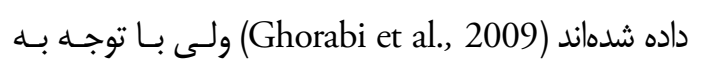

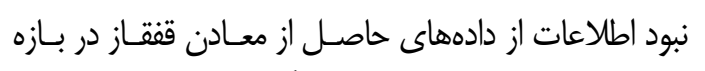

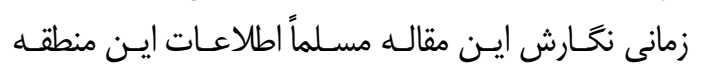
ناديده انكاشته شده است.

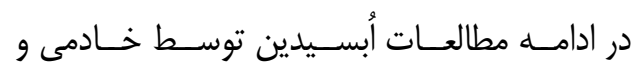

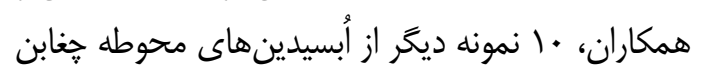

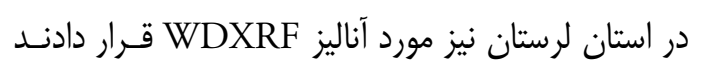
كه نتايج حاصله مشخص نمود كه در مجموع دو گَروه

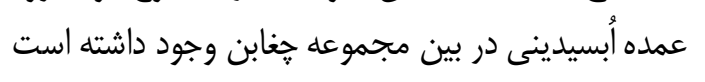
ولى هيج كدام از نمونهها از لحاظ تركيبات شيميايى بـا نمونههاى معادن شناختهشده در شمال غرب ايران، قفقاز و آناتولى همخوانى ندارند و اين احتمال را مطرح مي كنند

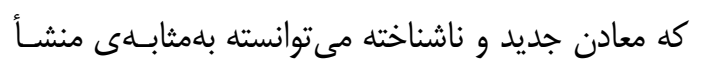
احتمالى أبسيدينهاى جغابن بوده باشد كه مسـلماً ايـن

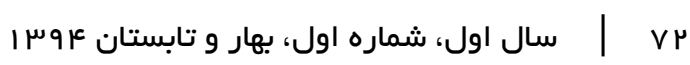


معلن استخراج شدهاند. در كنار اين •• نمونه دو قطعـهـ

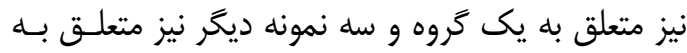

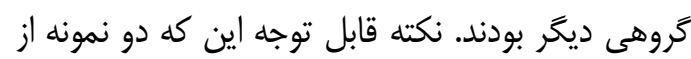

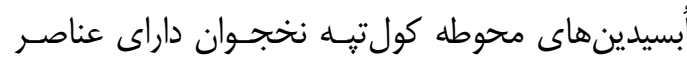

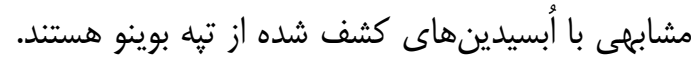

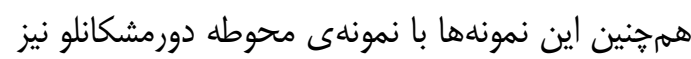
داراى شباهت ساختارى است. نغارندكان بر ايـن تاكيـــ دارند كه ساكنان اين محوطه از جند منبع مختلف جهاريت

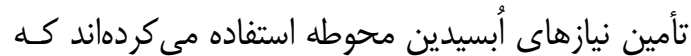

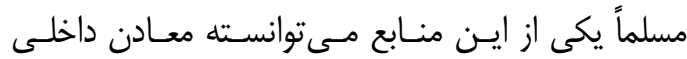

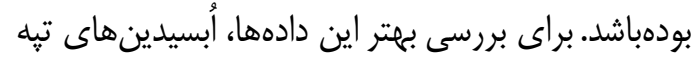

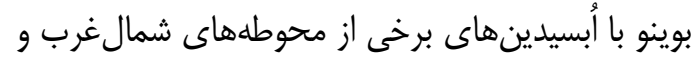

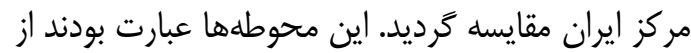

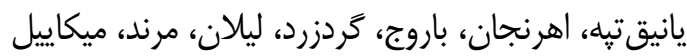

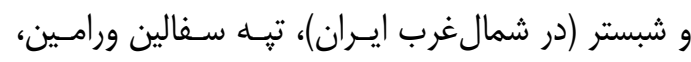

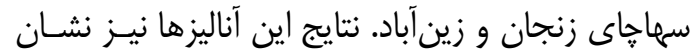

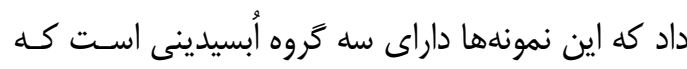

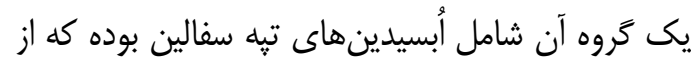

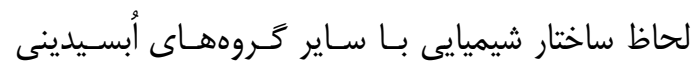

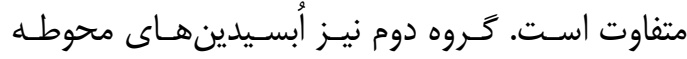

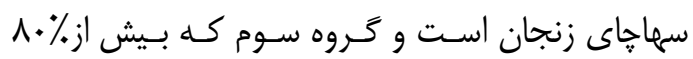

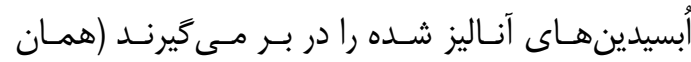

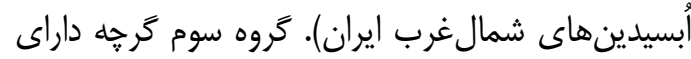
منشأ مشخص و اثبات شدهاى نيست ولى تا زمانى كـهـ

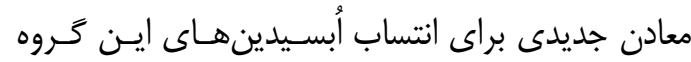

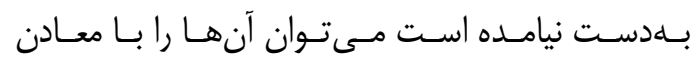

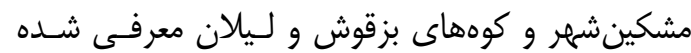
توسط نيكنامى و همكاران مقايسه نمود و بلمثنابهى منشأ كروه سوم در نظر گرفت (نورى • وجسا؛ نورى و همكاران

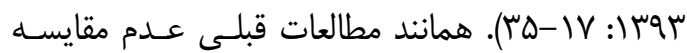
كافى دادهها با نمونههاى منطقه قفقاز و نيز نموند مانه معادن

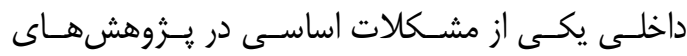

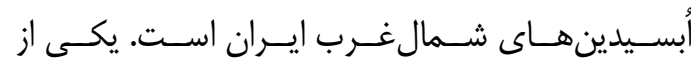

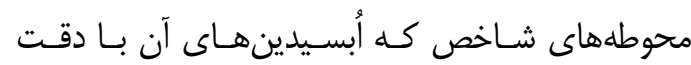

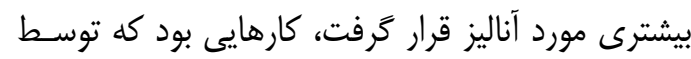
نغارنده و همكاران در محوطه كولتِّه هاديشهر به انجام

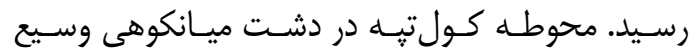

مرتبط با نمونه معلن قوناق گيران نبودند. ؟) گَروه سوم از

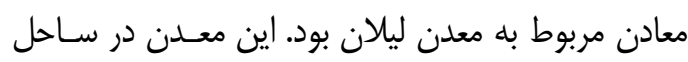
جنوبشرقى درياجه اروميه و در نزديكى شهر ملكان قرار

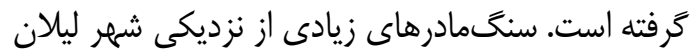

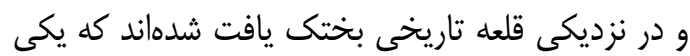

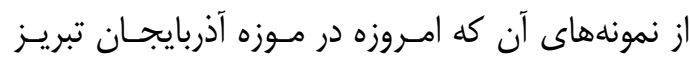

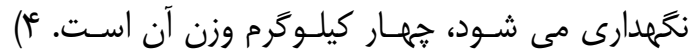
نمونههاى جهارم متعلق به مشكينشهر بود كه از لحاظ

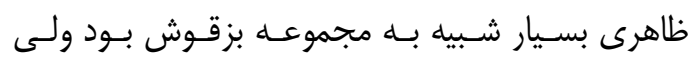

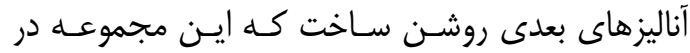
حقيقت سنگ جرت إن سياه رنخ بوده است و نه أبسـيدين (Niknami et al., 2010) مسأله و ابهـامى كـه ايسن يزوهش با آن مواجه بود اين است كه تنها سه نمونسه از

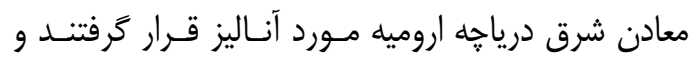
مسلماً اين تعداد براى تحليل در مورد اسـتخراج از ايـن إسن منابع در دوران باستان كافى بهنظر نمى دسد. ولى ايـن

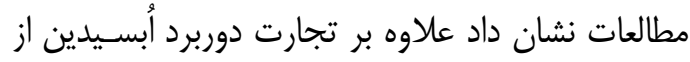

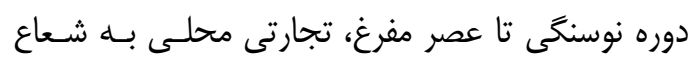

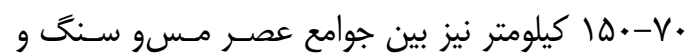

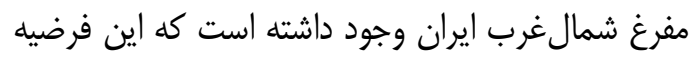

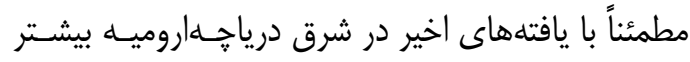

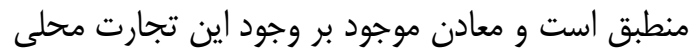
عمدتاً در شرق درياجٍ اروميه تاكيد دارن مارند

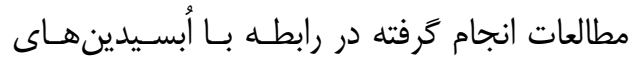

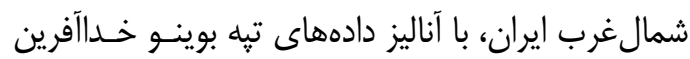

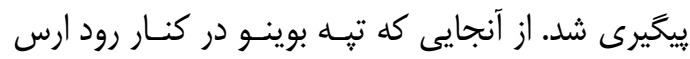

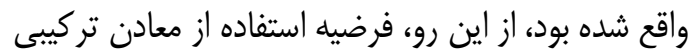
داخلى و خـارجى را ييشـنهاد مسى داد ولى بـاز در ايسن فين

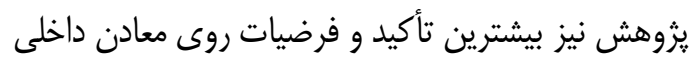

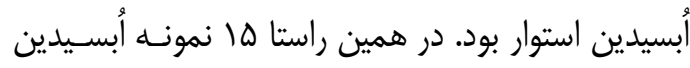

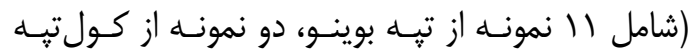

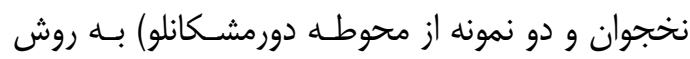

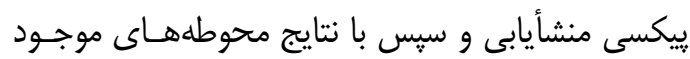

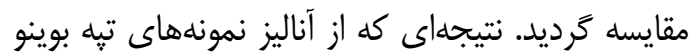

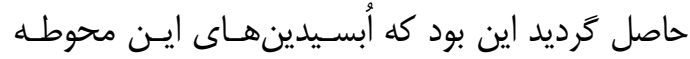

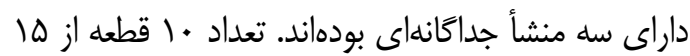

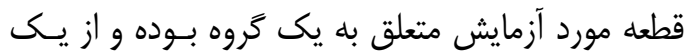


كولتبه استفاده شده بود معدن سيونيك با فاصله تقريبى

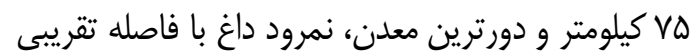

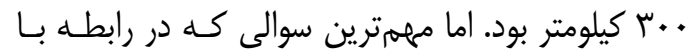

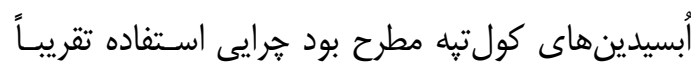

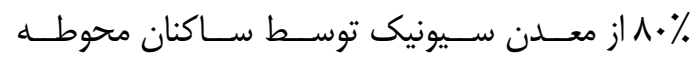

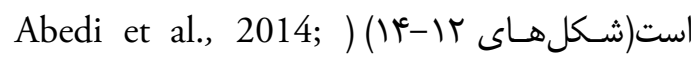
Khademi Nadooshan et al., 2013; Khazaee et (al., 2011

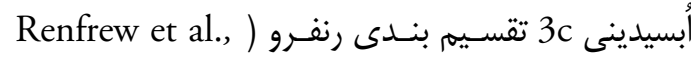
كـه از (1966: 66-67; Keller et al., 1996: 85

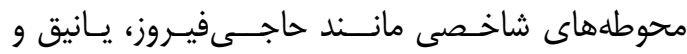

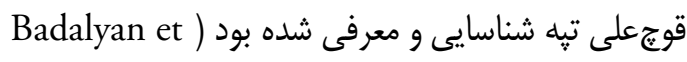
(al., 2004; Blackman et al., 1998: 213, 222 معـادن داخـلى مانند سهند و سبلان نسبت داده مى شد (Niknami et al., 2010) در دهل • 199 ميلادى و بعدها توسط شاتانيه و همكاران انجام كرفت مشخص ساخت كه معدن شاخص سيونيك

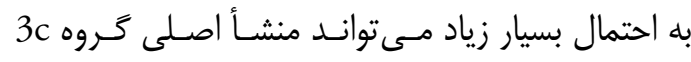

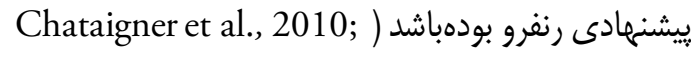
Keller and Seifreid 1990: 84; Badalyan et al.,

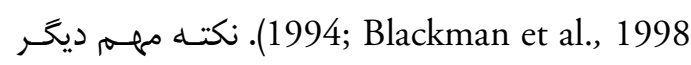

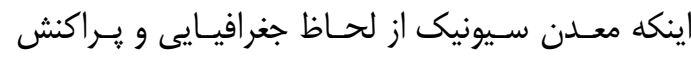

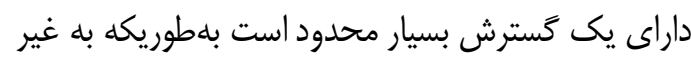

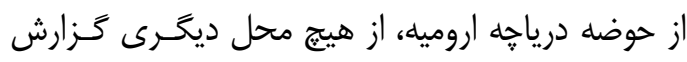

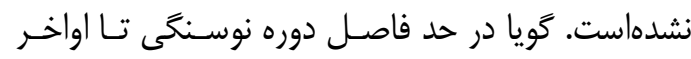

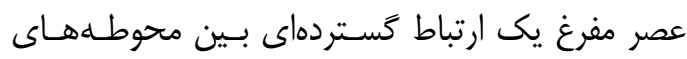

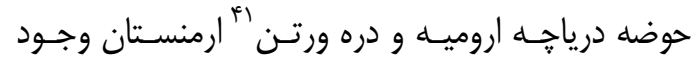

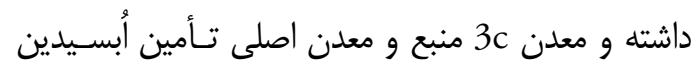

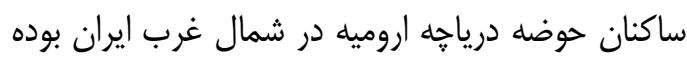

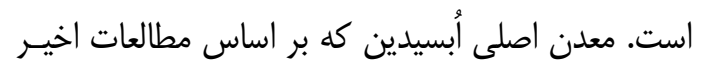

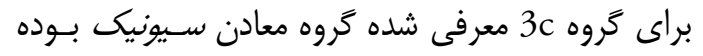

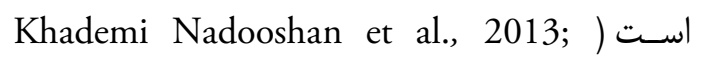

.(Chataigner et al., 2010 يكى ديخر از محوطههاى شاخص دوره نوسـنگى و مس و سنگ شمال غرب ايران كه توسط نَّارنده در طى نى

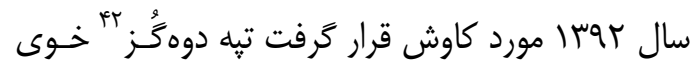

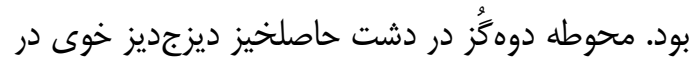

هاديشهر در شمالغربى ترين نقطه كشـور، و در حـدود

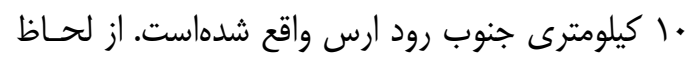

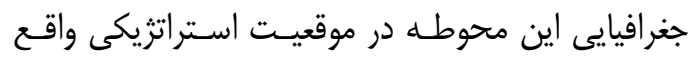

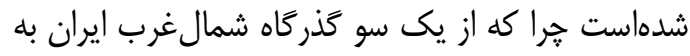

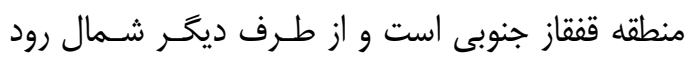

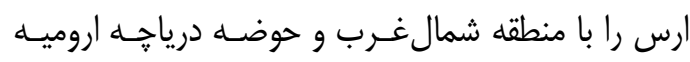

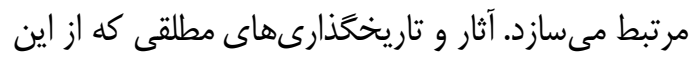
محوطه به انجام رسيد مشـخص سـاخت كـه محوطـهـ

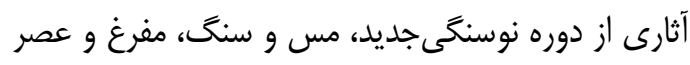

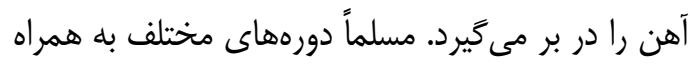

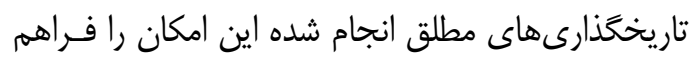

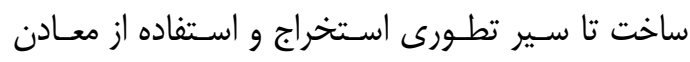

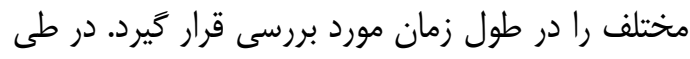

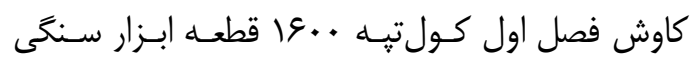
بهدست آمد كه از اين ميان • و9 قطعه از جنس أبسيدين

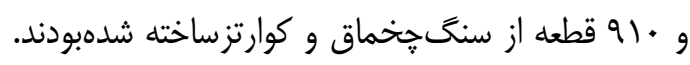

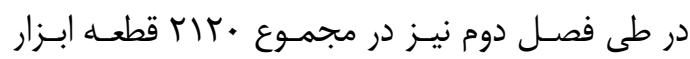

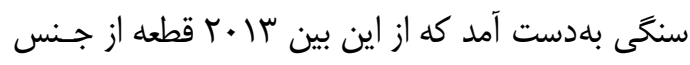

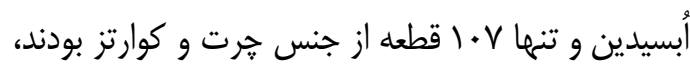

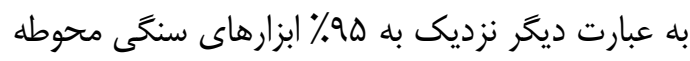

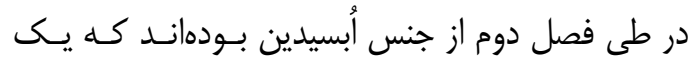

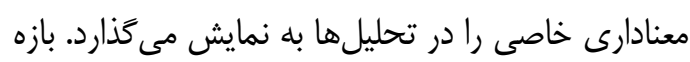

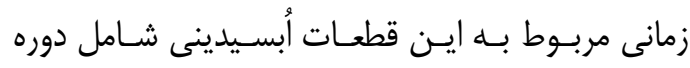

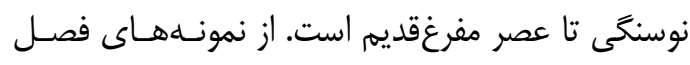

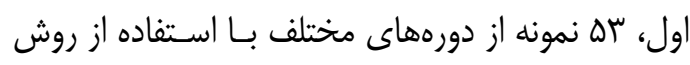

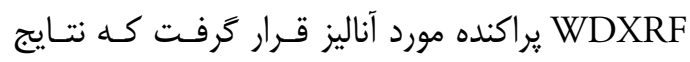

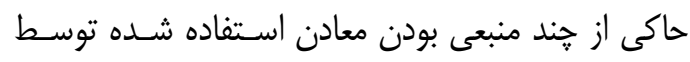

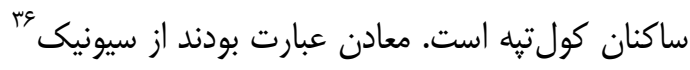

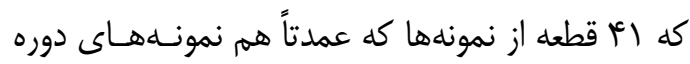
مسو سنَ و مفرغ قديم بودند از اين معسدن اسـتخراج

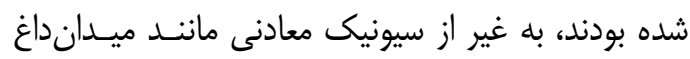
(جهار قطعه أبسيدينى)، نمرود داغ (دو قطعه أبسيدينى)،

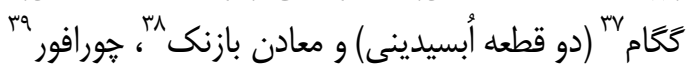

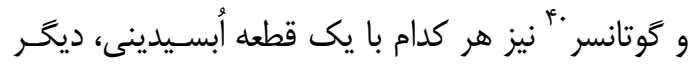

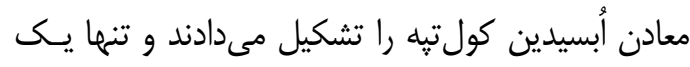

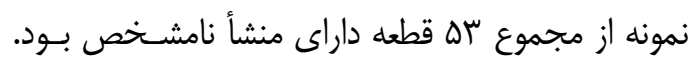

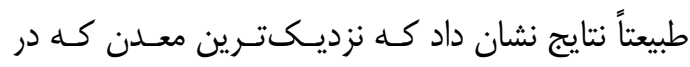


مرورى بر مطالعات ابسيدين در اير ان، منشأيابى معادن و ابسيدين هاى محوطه هاى باستانى بزوهاسبـ

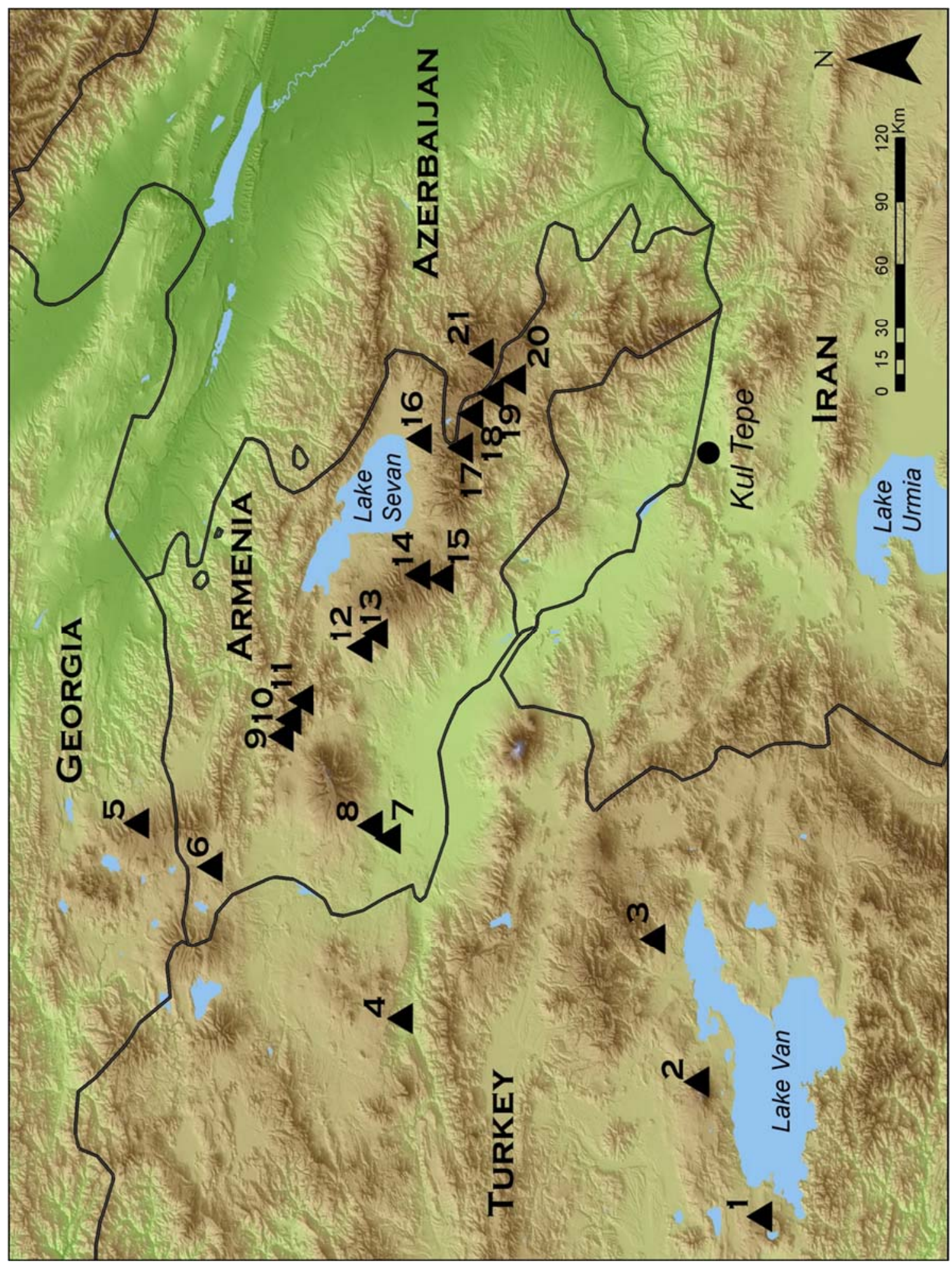

شكل rا: موقعيت جغرافيايى كول تِه جلفا و معادن أبسيدينى شناسايى شده در ارمنستان و تركيه توسط آزمايشكاه باستانسنجى

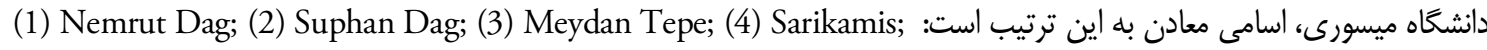

(5) Chikiani; (6) Ashotsk; (7) Pokr Arteni; (8) Metz Arteni; (9) Damlik-Hankavan; (10) Tsaghkunyats; (11)

Kamakar ; (12) Gutansar ; (13) Hatis ; (14) Geghasar; (15) Spitaksar; (16) Vardenis; (17) Choraphor; (18) Satanakar; (19) Syunik; (20) Bazenk; and (21) Kelbadzhar. 


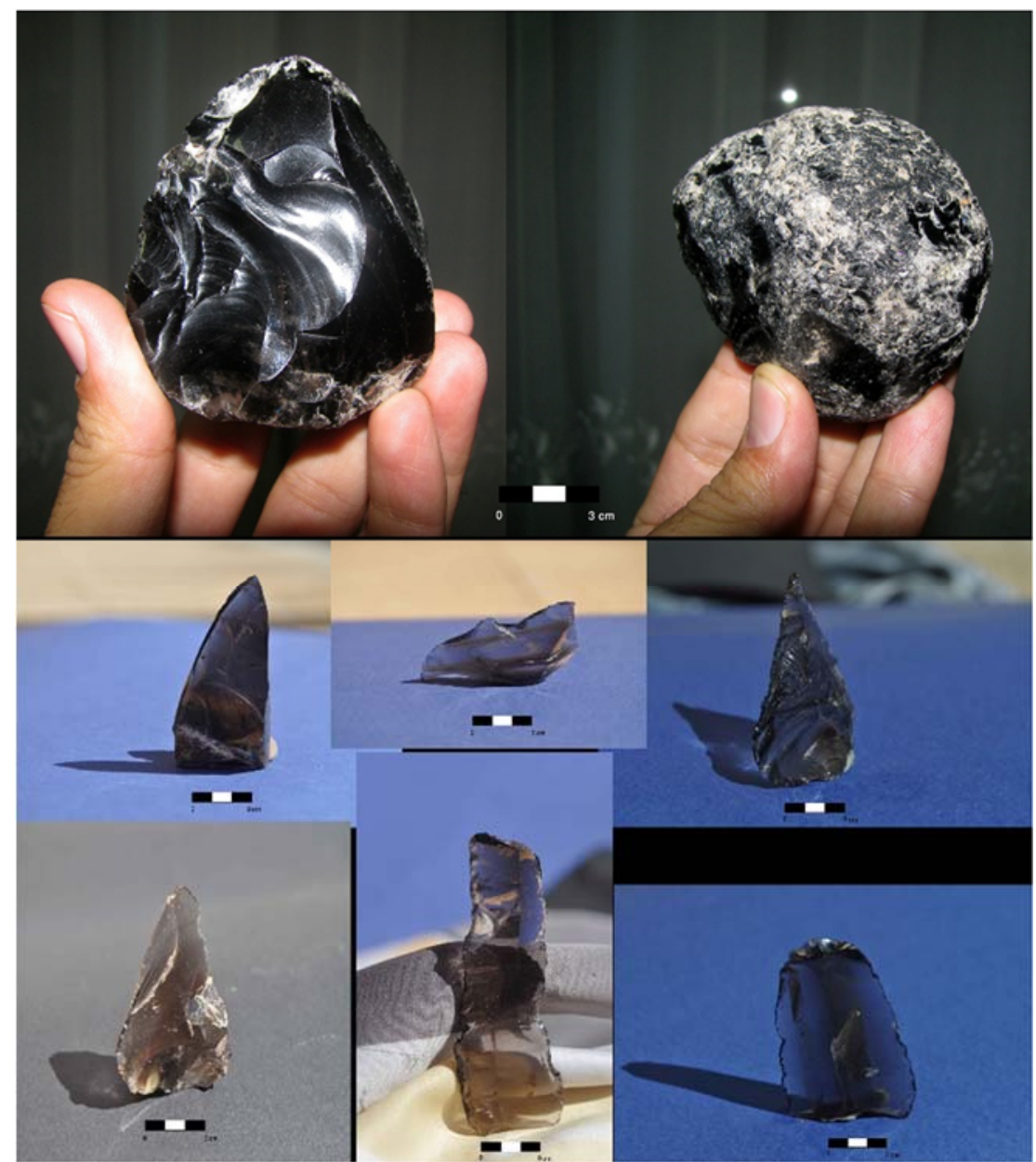

شكل "َا : نمونه ابزارهاى سنكى ابسيدينى به همراه سنگ مادر بهدست آمده از محوطه كولتيه جلفا

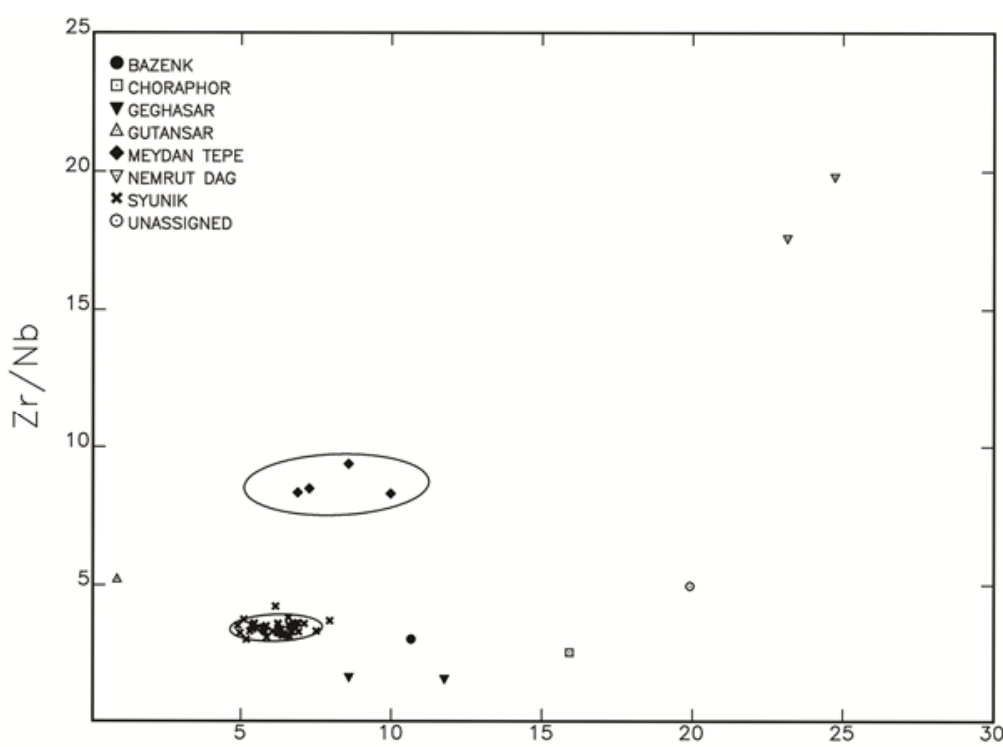

$\mathrm{Rb} / \mathrm{Sr}$

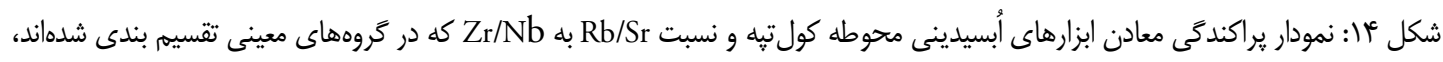
بيضى ها در سطح اطمينان \% . جرسم شدهاند. 
شرق در محوطه سنخَجخماق به مقــار بسـيار انـدكى

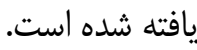

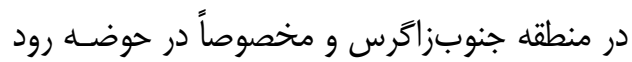

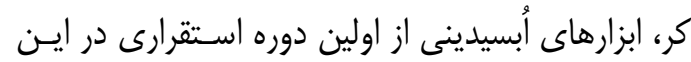

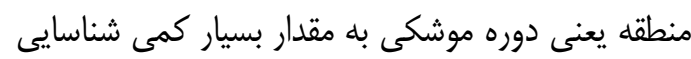

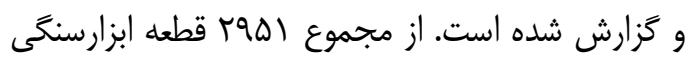

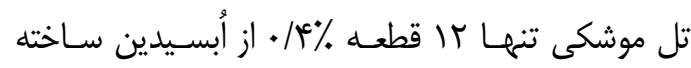

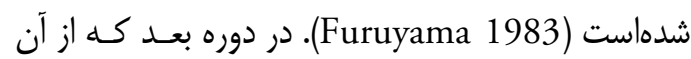

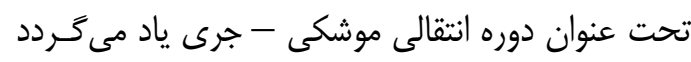

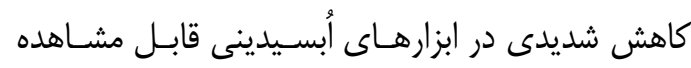

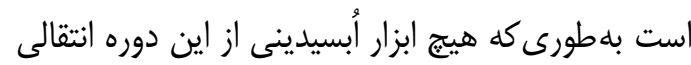

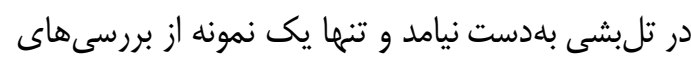

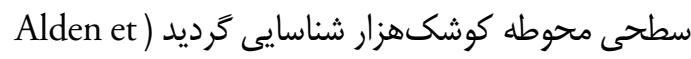

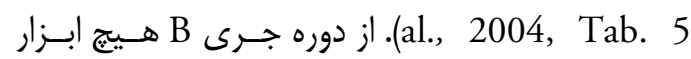

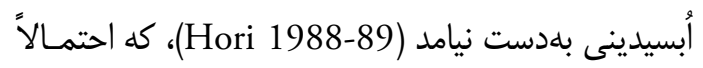

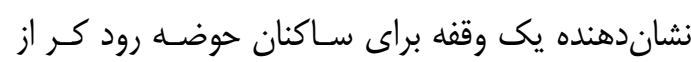
لحاظ دسترسى به منابع أبسيدين بودهاست. تعداد اندكى لئى

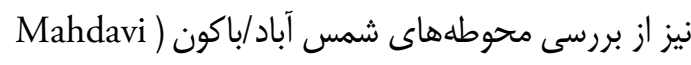
(and Bovington 1972, Tab. 1 شده تلباكون كزارش شدهاست. بـا وجـود اينكـهـ هـيـيج

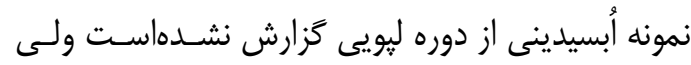

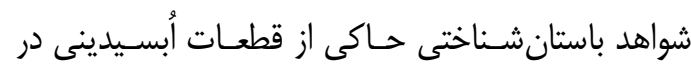

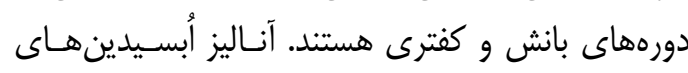

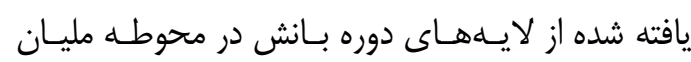

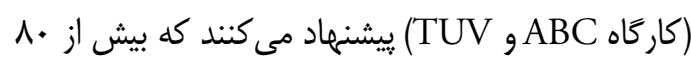
درصد يافتههاى أبسيدينى متعلق به معادن حوضه درياه

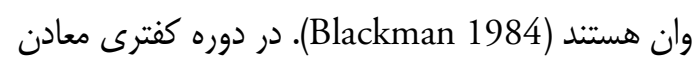

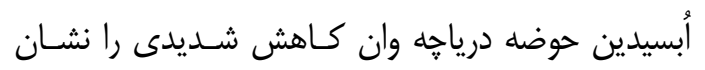
مىدهند (9 و\%) هرا كه استفاده از ساير معادن مانند قفقاز

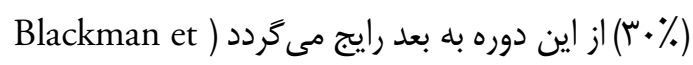

.al., 1998: 222; Abdi 2004

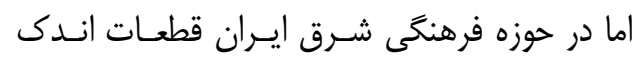

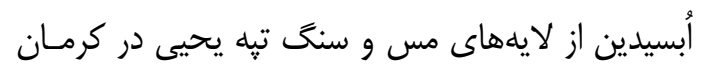

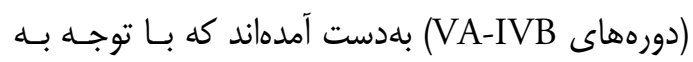
آناليزهاى بلكمن (دlackman 1984) منشأ اين قطعات

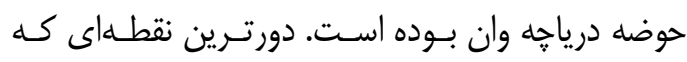

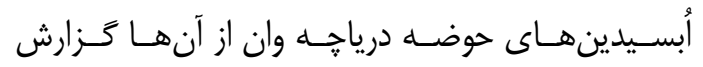

شمال درياجه اروميه واقع شـــه كـه يـك دشـت ميـان

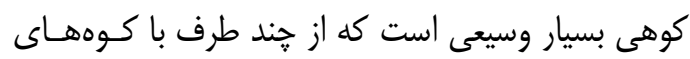

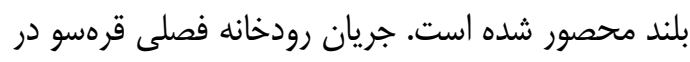
اين دشت يكى از عوامل اصلى شكل ثَيرى محوطـهــــا

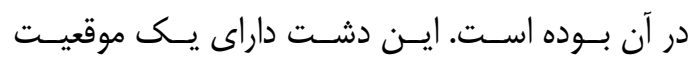

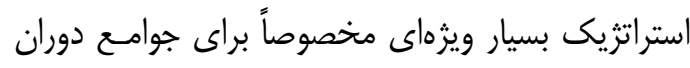

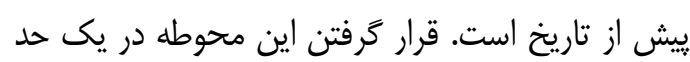

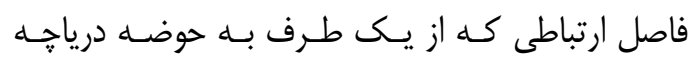

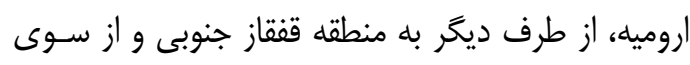

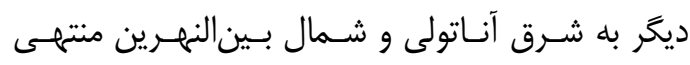

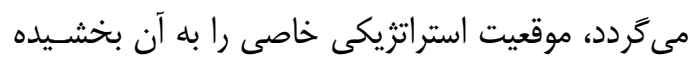

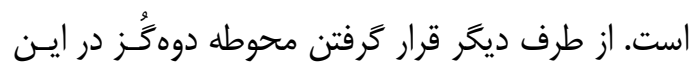

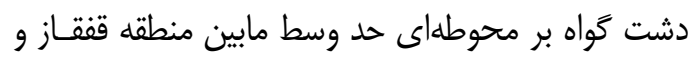

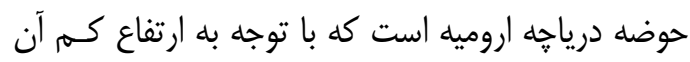

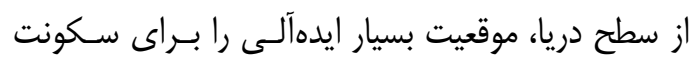

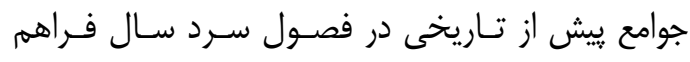

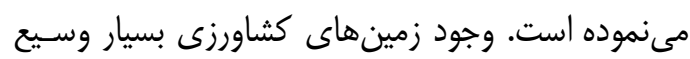

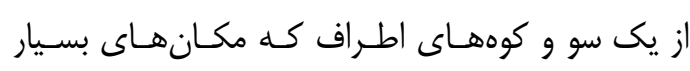

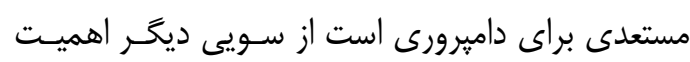

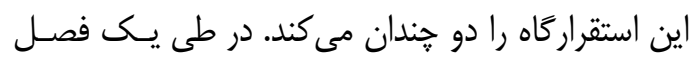

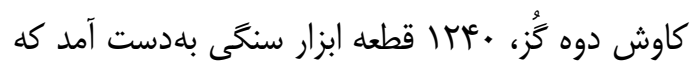

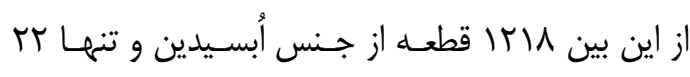

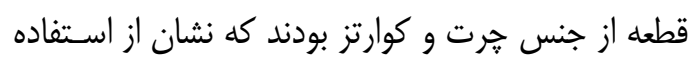

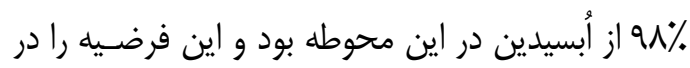

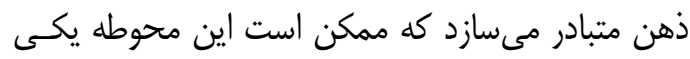

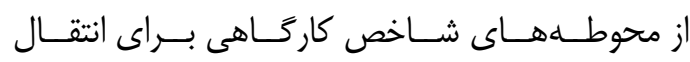

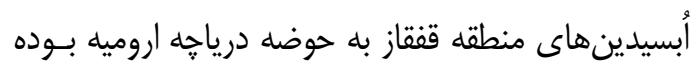

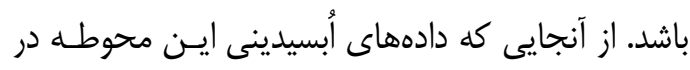

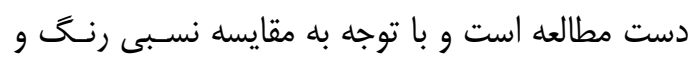

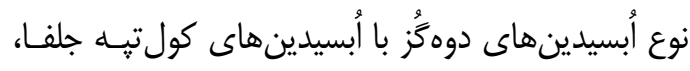

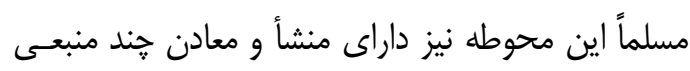

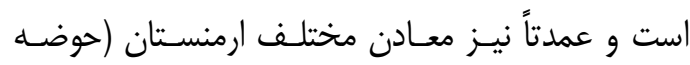

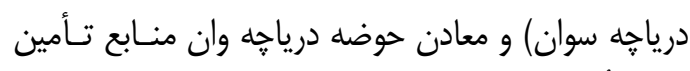

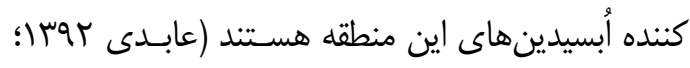

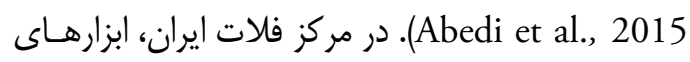

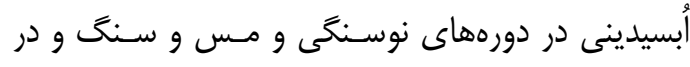

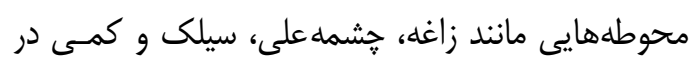




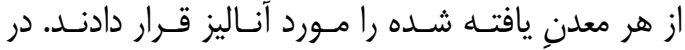

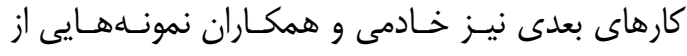
كوههاى آتشفشانى سهند و سبلان را مــورد آنـاليز قـرار دادند كه هيج اطلاعاتى در رابطه با اينكه اين نمونسهــا

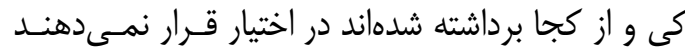

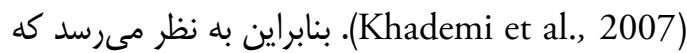

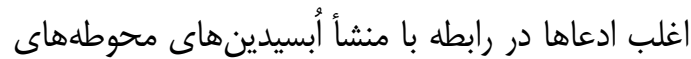

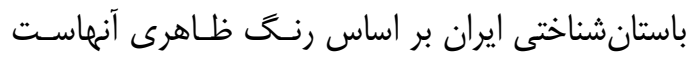

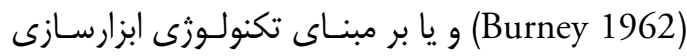

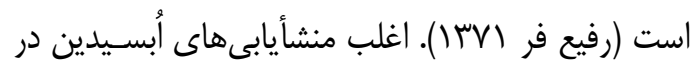

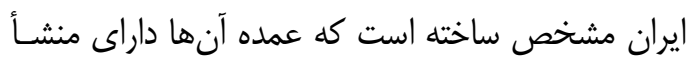

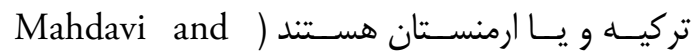
Bovington 1972; Renfrew 1977; Blackman 1994; Pullar et al., 1986; Badalyan et .1984, .(al., 2004; Glascock 2009; Frahm 2010: 282 اما اغلب اين منشأيابىها دو ايراد عمده داشتهاند: () هيج

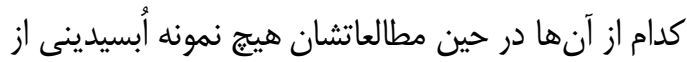

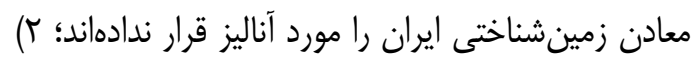

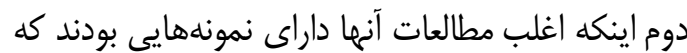
با هيج يك از معادن شناخته شده آنها قابل مقايسه نبود

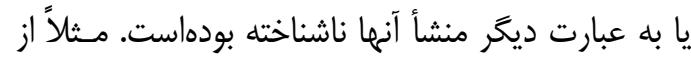

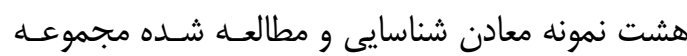
بلكمن (1984)، تنها نيمى از آنها داراى منبع مشخصى

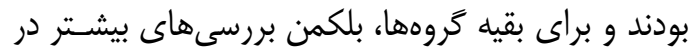

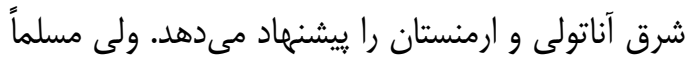

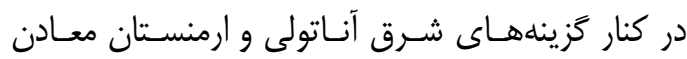
احتمالى ايران را نيز بايستى به آنها افزود.

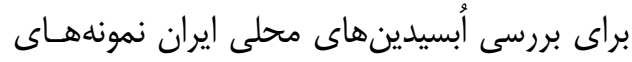
اندكى توسط گروه زمين شناسى دانشخاه تبريز و آقاى آناى

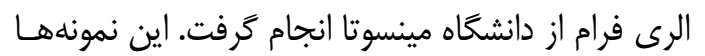
كه اغلب در مجموعه آزمايشگاهى دانشخاه تبريـز قـرار

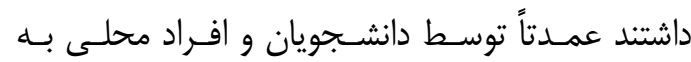
برداشتهايى از معادن محلى اطلاق كَرديده بودند. درون

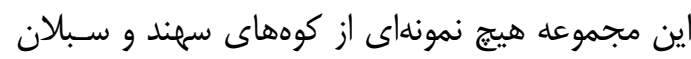

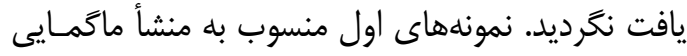

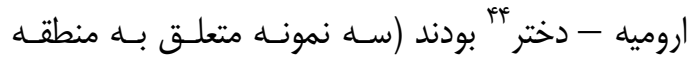

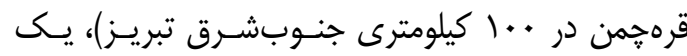

شدهاست مربوط به محوطهاى بلنام داهاران "َّر ساحل جنـوبى خلـيجفارس اسـت ( Renfrew and Dixon .(1977, Tab. 1

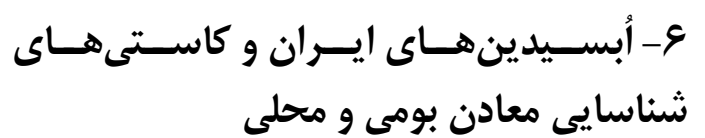

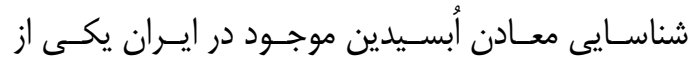

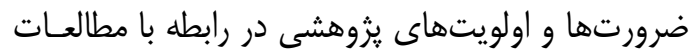

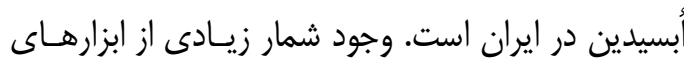

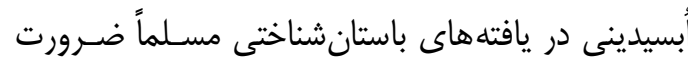
منشأيابى و شناسايى معادن آنها جهت بازسازى تبادلاتئات

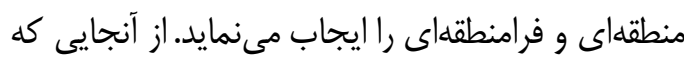

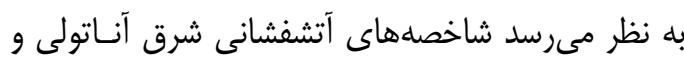

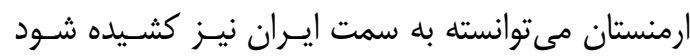
Dostal and Zerbi 1978, Innocenti et al., )

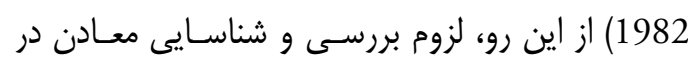

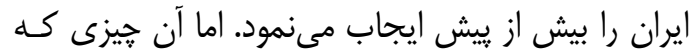

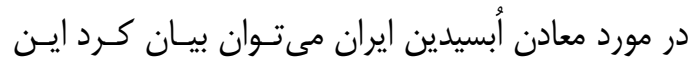

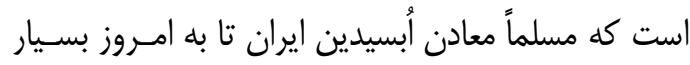

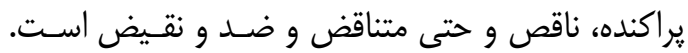

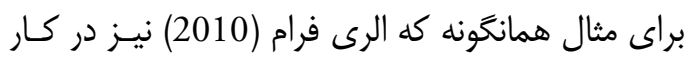

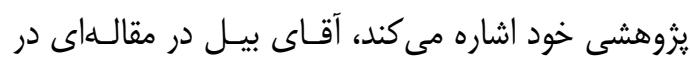

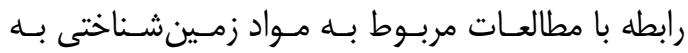
يكسرى از اطلاعات دست سوم اشاره مىنمايد ( Beale

روستاييان محلى در نزديكى تِّه يحيى كرمان ادعـا

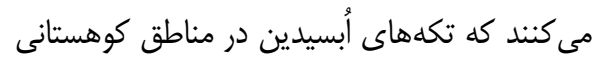
و آتشفشانى شرق يحيى و در منطقه بلوحتستان وجود

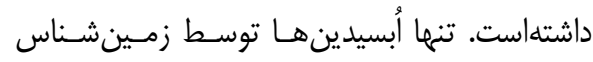

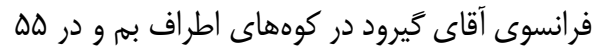

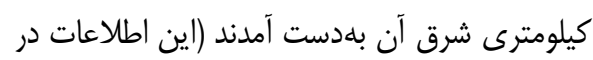

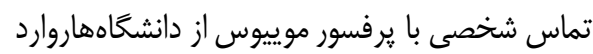

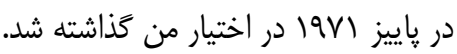
در ساير مطالعاتى هم كه توسط يزوهشكران ايرانى

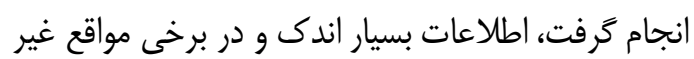

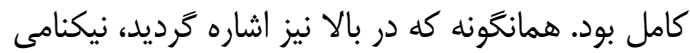
و همكارانش (Niknami et al., 2010) تنها يك نمونه 
شمال غرب ايران نشان داد كه در كنار معـادن شـاخص

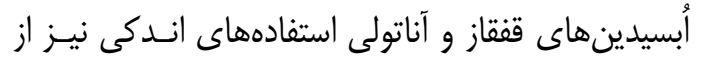

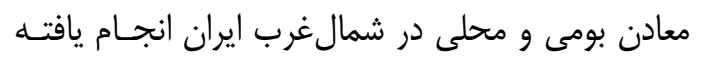

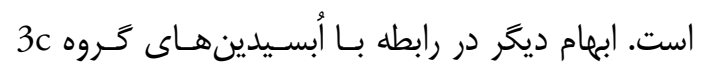

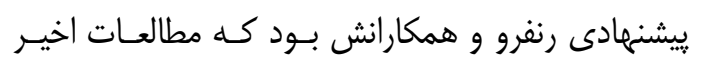
روشن ساخت كه معلن سيونيك در حوضه درياجه سوان

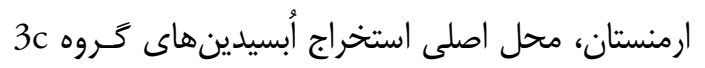

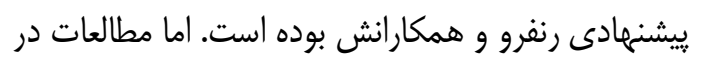

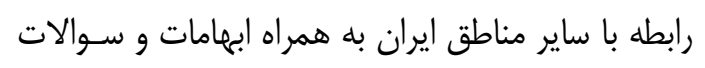
فراوان همجنان به قوت خود باقى و نيازمند يزوهش إنهاى بيشترى است.

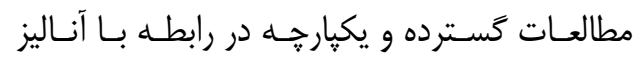

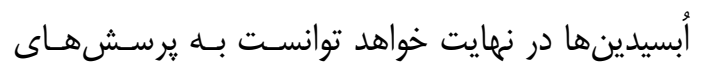

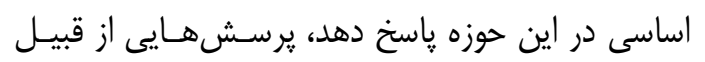

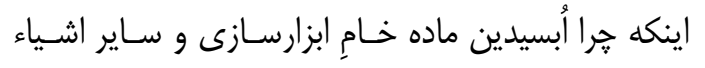

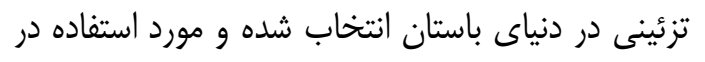

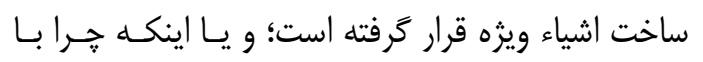
وجود معادن محلى در بيشتر مناطق خاور نزديك، معادن

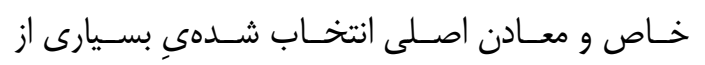

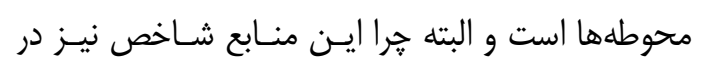
طول زمان تغيير مىيابند.

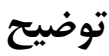

اين مقاله مستخرج از طرح بزوهشـى شناسـايى معـادن

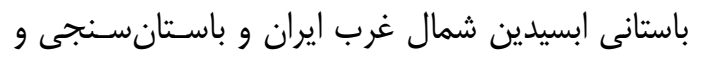

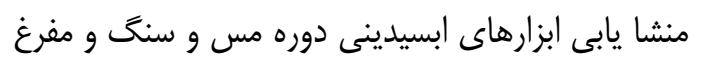
كول تبه به شمارهץrا

1. Olduvai Gorge

2. Homo Habilis

3. Homo Ergaster

4. Erectus

5. Awash Valley of Ethiopia

6. Renfrew, Dixon and Cann

7. Archaeology: Theories, Methods, and Practice
نمونه متعلق به مجموعه آتشفشانى ماكو (در نزديكى مرز

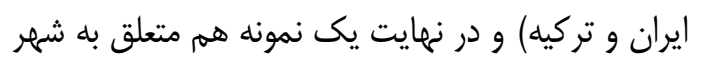

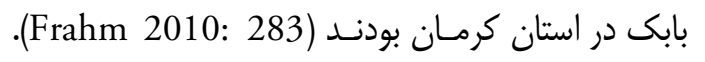

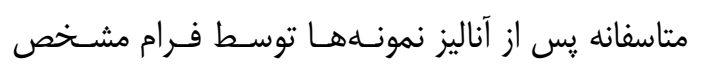
كرديد كه نمونههاى قرهجمن تركيبى از شيشه طبيعى و و

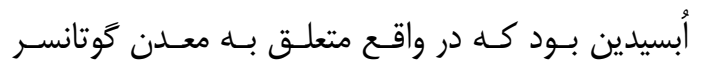

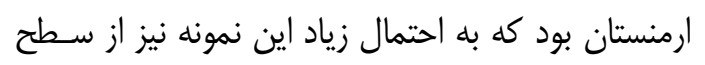

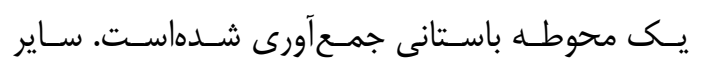

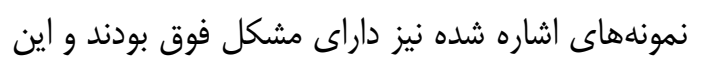
مسئله فرام را به اين نكته رهنمون ساخته است كه نه اتكاء

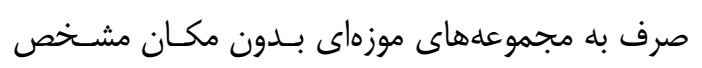

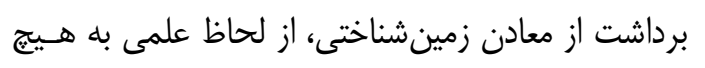

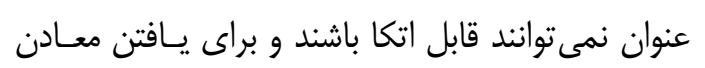

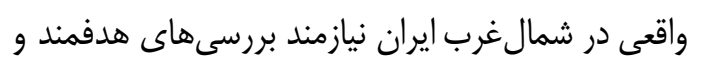
دقيق علمى باستان - زمين شناختى است.

\section{- نتيجل كيرى - V}

همانكونه كه اشاره ترديلد، مطالعات أبسـيدين در ايـران خلاف ساير مناطق خاورميانه و خاورنزديـك در مراحلـ إنسل

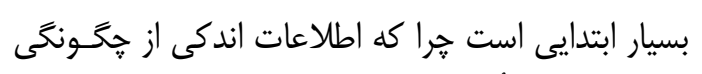

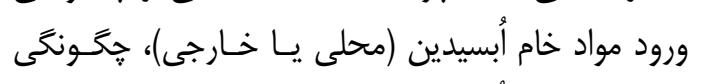

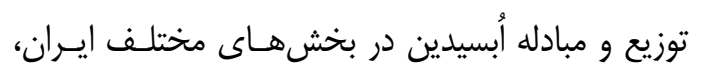

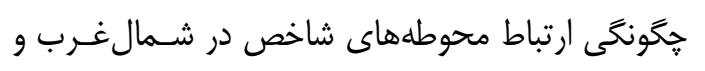

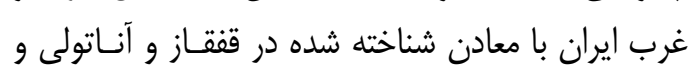

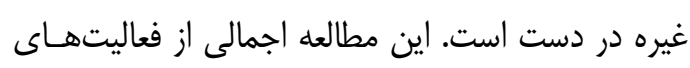

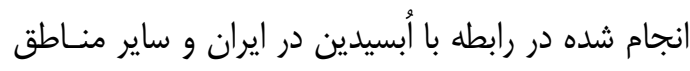

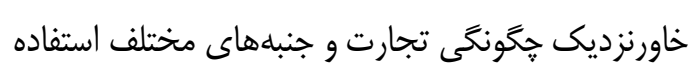

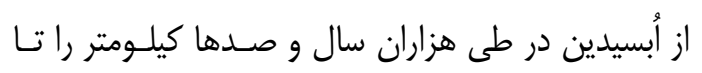

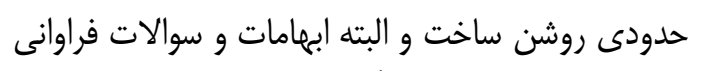

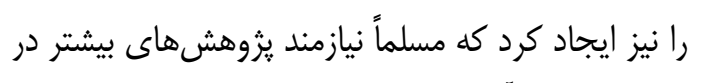
طى سالهاى آينده است.

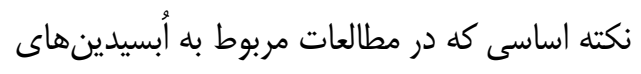

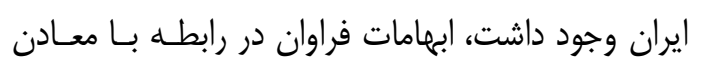

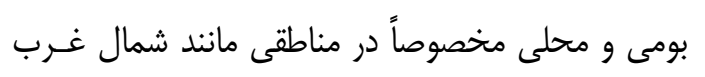

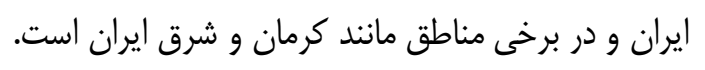

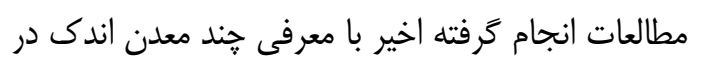




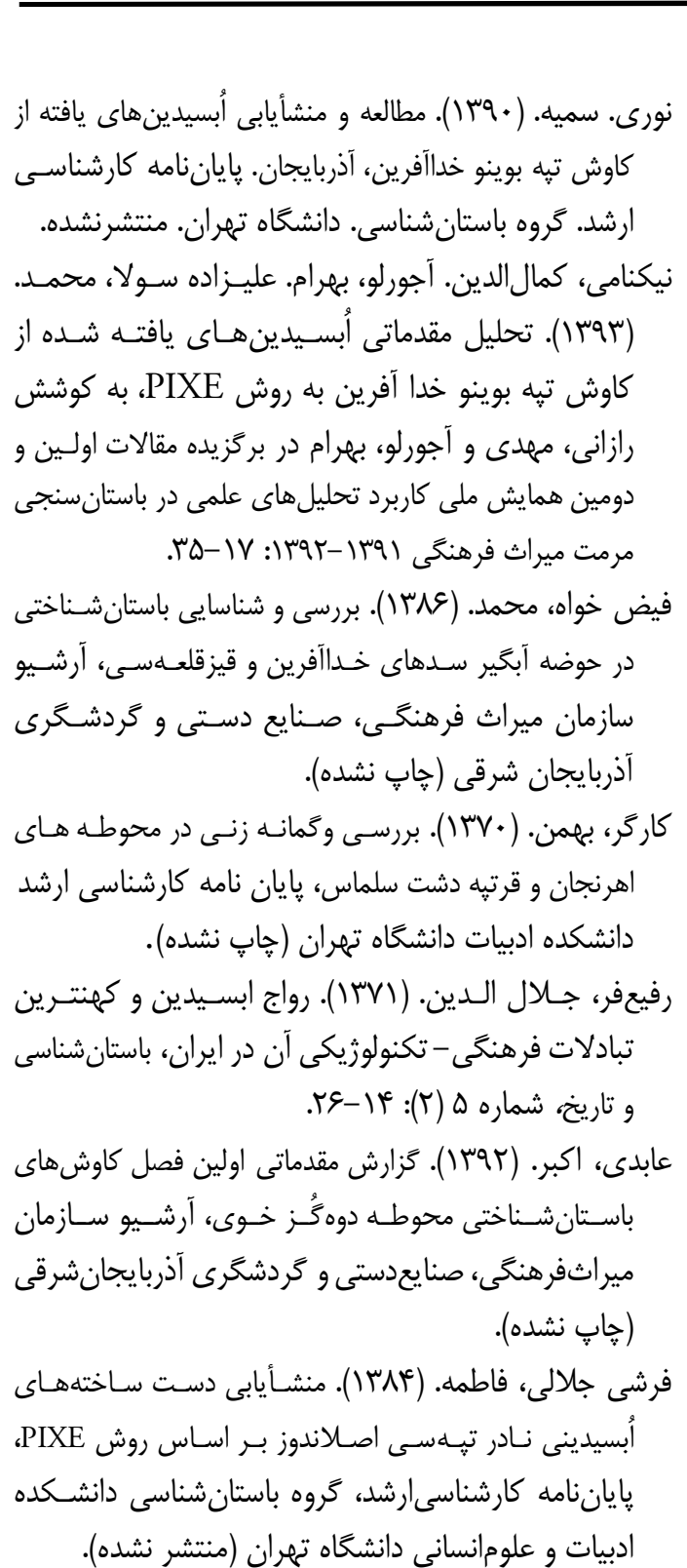

\section{منابع لاتين}

Abdi, K. (2004). Obsidian in Iran from the Epipaleolithic period to the Bronze Age. Splendor of Iran, 148-153.

Abdi, K., Nokandeh, G., Azadi, A., Biglari, F., Heydari, S., Farmani, D., Rezaii, A. and Mashkour, M. (2002). Tuwah Khoshkeh: A Middle Chalcolithic Pastoralist Campsite in the Islamabad Plain. Iran 40: 43-74.

Abedi, A., Khatib Shahidi, H., Chataigner, CH., Niknami, K., Eskandari, N., Kazempour, M., Pirmohammadi, A., Hoseinzadeh, J., Ebrahimi, GH. (2014). "Excavation at Kul Tepe of (Jolfa), North-Western Iran, 2010: First Preliminary Report", Ancient Near Eastern Studies. Vol. 51: 33-167.
8. Jean-Jacques de Morgan

9. optical emission spectroscopy

10. Supply zone

11. Contact zone

12. fall-off curves

13. Law of Monotonic Decrement

14. fall-off rates

15. down the line

16. exponential decline

17. Obsidian interaction zone

18 . gravity model

19. attractiveness

20. simple random-walk patterns

21. Flaked-stone artifacts

22. Yağlar

23. Sakaeli-Orta

24. Sakaeli-Orta (Galatia X)

25. X-Ray Flourescence (XRF)

26. Neutron Activation Analysis (NAA)

27. Bingöl A

28. Nemrut Dağ

29. Bayezid

30. Meydan Dağ or Tendürek Dağ

31. $\mathrm{Mn} / \mathrm{NA}$ ratios

32. Hasan Dağ

33. Proton Induced X-ray Emission (PIXE)

34. Wavelength Dispersive X-ray Fluorescence (WDXRF)

35. Ashanah

36. Syunik

37. Gegham

38. Bazenk

39. Choraphor

40. Gutansar

41. Vorton Valley

42. Dava Göz

43. Dhahran

44. Urumieh-Dokhtar-Magmatic Arc

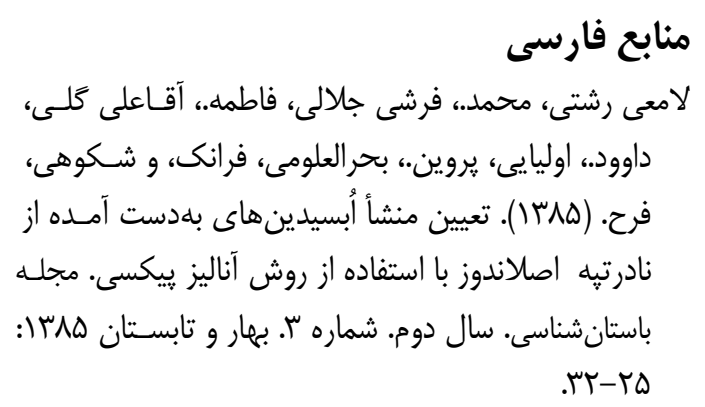

سال اول، شماره اول، بهار و تابستان ع و ا 
Abedi, A., Omrani, B. and Karimifar, A. (2015).Fifth millennium BC in north-western Iran Dalma and Pisdeli revisited. Documenta Praehistorica XLII: 1-19.

Acquafredda, P., Andriani, T., Lorenzoni, S., and Zanettin, E. (1999) Chemical Characterization of Obsidians from Different Mediterranean Sources by Non-Destructive SEM-EDS Analytical Method. Journal of Archaeological Science 26 (3): 315-325.

Agha-Aligol, D., Lamehi-Rachti, M., Oliaiy, P., Shokouhi, F., Farmahini Farahani, M., Moradi, M., and Farshi Jalali, F. (2015). Characterization of Iranian Obsidian Artifacts by PIXE and Multivariate Statistical Analysis, Geoarchaeology, Vol. 30 (3): 261-270.

Alden, J. R., Abdi, K., Azadi, A., Biglari, F. and Heydari, S. (2004). Kushk-e Hezar: A Mushki/Jari Period Site in Kur River Basin, Fars,. Iran 42: 47-61.

Alizadeh, A. (2003). Excavations at the Prehistoric Mound of Chogha Bonut, Khuzestan, Iran: seasons 1976/77, 1977/78, and 1996. Oriental Institute Publications 120. Chicago, The Oriental Institute of the University of Chicago.

Ambrose, W. R., Allen, C., O'Connor, S., Spriggs, M., Oliveira, N. V., and Reepmey, C. (2009). Possible Obsidian Sources for Artifacts from Timor: Narrowing the Options Using Chemical Data. Journal of Archaeological Science 36(3):607-615.

Aspinall, A., Feather, S., and Renfrew, C. (1972). Neutron Activation Analysis of Aegean Obsidians. Nature 237(5354): 333-334.

Badalyan, R., Chataigner, C., and Kohl, P. (2004). Trans-Caucasian Obsidian: The Exploitation of the Sources and Their Distribution. In Sagona, A. (Ed.), A Viewfrom the Highlands: Archaeological Studies in Honour of Charles Burney: 437465. Ancient Near Eastern Studies.

Badalyan, R., Kikodze, Z., and Kohl, P. (1994). Neutronic activation analysis of Caucasian obsidian: sources and models of procurement and distribution (Neolithic period-Early Iron Age). In: Masson, V. (ed.), Izuchenie drevnikh kultur $i$ tsivilizatsij: 87-92. St. Petersburg (in Russian).

Beale, T. (1973). Early Trade in Highland Iran: A View from a Source Area. World Archaeology 5(2):133-148

Bellot-Gurlet, L., Le Bourdonnec, F.-X., Poupeau, G., and Dubernet, S. (2004). Raman MicroSpectroscopy of Western Mediterranean Ob- sidian Glass: One Step Towards Provenance Studies? Journal of Raman Spectroscopy 35 (89): 671-677.

Bigazzi, G., Poupeau, G., Yeingil, Z., and BellotGurlet, L. (1998). Provenance Studies of Obsidian Artefacts in Anatolia Using the FissionTrack Dating Method: An Overview. In Cauvin, M.C., Gourgaud, A., Gratuze, B., Arnaud, N., Poupeau, G., Poidevin, J.L., and Chataigner, C. (Eds.), L'obsidienne au Proche et Moyen-Orient: Du Volcan à l'Outil: 70-89. BAR International Series.

Blackman, M. (1984). Provenance Studies of Middle Eastern Obsidian from Sites in Highland Iran. In Lambert, J. B. (Ed.), Archaeological Chemistry III: 19-50.

Blackman, M. J., Badalyan, R., Kikodze, Z., and Kohl, P. L. (1998). Chemical Characterization of Caucasian Obsidian Geological Sources. In Cauvin, M.C., Gourgaud, A., Gratuze, B., Arnaud, N., Poupeau, G., Poidevin, J.L., and Chataigner, C. (Eds.), L'obsidienne au Proche et Moyen-Orient: Du Volcan à l'Outil: 205-231. BAR International Series.

Burney, C. A. (1962). The excavations at Yanik Tepe, Azerbaijan, 1961 Second Preliminary Report, Iraq 24: 134-152.

Burney, C. A. (1964). The excavations at Yanik Tepe, Azerbaijan, 1962: Third Preliminary Report, Iraq 26: 54-61.

Cann, J. R., Dixon, J. E. and Renfrew, C. (1968). The Sources of Saliagos Obsidian. In Evans, J. D., and Renfrew, C. (Eds.), Excavations at Saliagos Near Antiparos: 105-107. vol. 5. British School at Athens.

Cann, J. R., Dixon, J. E. and Renfrew, C. (1969). Obsidian Analysis and the Obsidian Trade. In Brothwell, D. R., and Higgs, E. (Eds.), Science in Archaeology: A Survey of Progress and Research, Revised and Expanded Edition: 578-591. Praeger Publishers, New York.

Cann, J.R., and Renfrew, C. (1964). The Characterization of Obsidian and its Application to the Mediterranean Region. Proceedings of the Prehistoric Society 30: 111-133.

Carter, E., Hargreaves, M., Kononenko, N., Graham, I., Edwards, H., Swarbrick, B., and Torrence, R. (2009). Raman Spectroscopy Applied to Understanding Prehistoric Obsidian Trade in the Pacific Region. Vibrational Spectroscopy 50 (1): 116-124.

Chataigner, C., Avetisyan, P., Palumbi, G., Uer- 
pmann, H., 2010. Godedzor, a Late Ubaid-related site in the southern Caucasus. In: Carter, R., Philip, G. (Eds.), The Ubaid and Beyond: Exploring the Transmission of Culture in the Developed Prehistoric Societies of the Middle East. Proceedings of the International Conference on the Ubaid, Durham, April 20-22, 2006.

Chataigner, C., J. Poidevin and N. Arnaud. 1998 Turkish Occurrences of Obsidian and Use by Prehistoric Peoples in the Near East from 14,000 to 6000 BP. Journal of Volcanology and Geothermal Research 85(1-4):517-537.

Chataigner, Ch. (1998). Sources des artefacts $d u$ Proche Orient d'après leur caractérisation géochimiques. In: Cauvin et al., 1998, 273-324.

Constantinescu, B., Bugoi, R., and Sziki, G. (2002). Obsidian Provenance Studies of Transylvania's Neolithic Tools Using PIXE, MicroPIXE and XRF. Nuclear Instruments and Methods in Physics Research B 189: 373-377.

Crawford, H. (1978). The Mechanics of the Obsidian Trade: A Suggestion. Antiquity 52:129132.

Darabi, H. and Glascock, M. D. (2013). The source of obsidian artefacts found at East Chia Sabz, Western Iran, Journal of Archaeological Science 40: 3804-3809.

de Morgan, J. J. (1927). Prehistoire Orientale III. Geuthner, Paris.

Dixon, J. E. (1976). Obsidian Characterization Studies in the Mediterranean and Near East. In Taylor, R. E. (Ed.), Advances in Obsidian Glass Studies: archaeological and geochemical perspectives. Noyes Press, Park Ridge, New Jersey.

Dixon, J., Cann, J. and Renfrew, C. (1968). Obsidian and the Origins of Trade. Scientific American 218(3): 38-46.

Dixon, J., Cann, J., and Renfrew, C. (1968). Obsidian and the Origins of Trade. Scientific American 218(3): 38-46.

Dostal, J. and Zerbi. M. (1978). Geochemistry of the Savalan Volcano (Northwestern Iran). Chemical Geology 22: 31-42.

Duranni, S., Khan, M. T., and Renfrew, C. (1971). Obsidian Source Identification by Fission Track Analysis. Nature 233: 242-252.

Frahm, E. (2010). The Bronze-Age Obsidian Industry at Tell Mozan (Ancient Urkesh), Syria. Ph.D. dissertation, Department of Anthropology, University of Minnesota.

Frahm, E. (2012) Fifty Years of Obsidian Sourcing in the Near East: Considering the Archaeologi- cal Zeitgeist and Legacies of Renfrew, Dixon, and Cann. International Association for Obsidian Studies Bulletin 47: 7-18.

Francaviglia, V. (1984). Characterization of Mediterranean Obsidian Sources by Classical Petrochemical Methods. Preistoria Alpina 20: 311332.

Francaviglia, V. (1990). Characterization of Mediterranean Obsidian Sources by Classical Petrochemical Methods. Preistoria Alpina 20: 311332.

Furuyama, M. (1983). Chipped Stone Tool Types at Tall-i Mushki, Iran. Bulletin of the Ancient Orient Museum 5: 109-119.

Gebel, H. G. (1994). Die Silexindustrie von Qaleh Rostam, NE-Zagros, Iran. In Gebel, H. G. and Kozlowski, S. K. (ds.), Neolithic Chipped Stone Industries of the Fertile Crescent. Studies in Early Near Eastern Production, Subsistence, and Environment 1: 117-142, Berlin.

Ghorabi, S., Glascock, M. D., Khademi, F., Rezaie, A., and Feizkhah, M. (2008). A Geochemical Investigation of Oobsidian Aartifacts from Sites in North-Western Iran, IAOS Bulletin, 39: $7-10$.

Glascock, M. D. (2009). Provenance Studies on Obsidian Artifacts from Early Neolithic Iran. In Geological Society of America Abstracts with Programs: 553. vol. 41, Portland, Oregon.

Glascock, M. D., Braswell, G. and Cobean, R. H. (1998). A Systematic Approach to Obsidian Source Characterization. In Shackley, M. S. (Ed.) Archaeological Obsidian Studies: Method and Theory: 15-65. Society for Archaeological Sciences.

Gourgaud, A. (1998). Géologie de L'obsidienne. In L'obsidienne au Proche et Moyen-Orient: Du Volcan à l'Outil, In Cauvin, M. C., Gourgaud, A., Gratauze, B., Arnaud, N., Poupeau, G., Poidevin, J. L. and Chataigner, C. (Eds.): 1529. British Archaeological Reports. Maison de l'Orient Méditerranéen, Archaeopress, Oxford.

Hallam, B. R., Warren, S. E., and Renfrew, C. (1976). Obsidian in the Western Mediterranean: Characterisation by Neutron Activation Analysis and Optical Emission Spectroscopy. Proceedings of the Prehistoric Society 42: 85-110.

Hodder, I., and Orton, C. (1976) Spatial Analysis in Archaeology. New Studies in Archaeology. Cambridge University Press.

Hole, F. (1977). Studies in the Archaeological History of the Deh Luran Plain: The Excavation of 
Chogha Sefid. Memoir 9. Ann Arbor, University of Michigan Museum of Anthropology.

Hole, F., Flannery, K. V., and Neely, J. A. (1969). Prehistory and Human Ecology of the Deh Luran Plain. Memoir 1. Ann Arbor, University of Michigan Museum of Anthropology.

Hori, A. (1988-89) Chipped Stone Artifacts from Tape Djari B, Iran. Bulletin of the Ancient Orient Museum 10: 21-46.

Innocenti, F., Manetti, P., Mazzuoli, R., Pasquarè, G. and Villari, L. (1982). Anatolia and NorthWestern Iran. In Andesites: Orogenic Andesites and Related Rocks, edited by R. S. Thorpe, pp. 327-349. John Wiley \& Sons.

Izuho, M. and Sato, H. (2007). Archaeological Obsidian Studies in Hokkaido, Japan: Retrospect and Prospects. Indo-Pacific Prehistory Association Bulletin 27: 114-121.

Keller, J., and Seifried, C. (1990). The present status of obsidian source identification in Anatolia and the Near East. In: Albore Livadie, C., Wiedemann, F. (Eds.), PACT, vol. 25: 58-87.

Keller, J., Djerbashian, E., Pernicka, E., Karapetian, S., and Nasedkin, V. (1996). Armenian and Caucasian Obsidian Occurrences as Sources for the Neolithic Trade: Volcanological Setting and Chemical Characteristics. In Archaeometry 94: The Proceedings of the 29th International Symposium on Archaeometry; Ankara, 9-14 May 1994: 69-86.

Khademi Nadooshan, F., Abedi, A., Glascock, M. D., Eskandari, N. and Khazaee, M. (2013). Provenance of prehistoric obsidian artefacts from Kul Tepe, northwestern Iran using X-ray Fluorescence (XRF) analysis, Journal of Archaeological Science 40, no. 4: 1956-1965.

Khademi Nadooshan, F., Ayvatvand, M., Dehghanifar, H., Glascock, M. D., and Colby P.S. (2010). Report on the Chogabon site, a new Source of obsidian artifacts in west -central Iran, IAOS Bulletin 42: 9-12.

Khademi Nadooshan, F., Colby Philips, S., and Safari, M. (2007). WDXRF Spectroscopy of Obsidian Tools in the North-West of Iran, IAOS Bulletin, 37: 3-6.

Khalidi, L. (2009). Holocene Obsidian Exchange in the Red Sea Region. In Petraglia, M. D. and Rose, J. I. (Eds.), The Evolution of Human Populations in Arabia: Paleoenvironments, Prehistory, and Genetics: 279-291. Springer.

Khalidi, L., Gratuze, B., and Boucetta, S. (2009). Provenance of Obsidian Excavated from Late
Chalcolithic Levels at the Sites of Tell Hamoukar and Tell Brak, Syria. Archaeometry 51(6): 879-893.

Khazaee, M., Gloscock, M. D., Masjedi, P., Abedi, A. and Nadooshan, F. K. (2011). The Origins of Obsidian Tools from Kul Tepe, Iran, IAOS Bulletin, No. 45 Summer: 14-18.

Kim, J., Kim, D., Youn, M., Yun, C., Park, G., Woo, H., Hong, M. Y., and Lee, G. (2007). PIXE Provenancing of Obsidian Artefacts from Paleolithic Sites in Korea. Indo-Pacific Prehistory Association Bulletin 27: 122-128.

Kuzmin, Y. V. (2006). Recent Studies of Obsidian Exchange Networks in Prehistoric Northeast Asia. In Dumond, D. E., and Bland, R. L. (Eds.), Archaeology in Northeast Asia: On the Pathway to Bering Strait: 61-71. University of Oregon, Eugene.

Kuzmin, Y. V. and Glascock, M. D. (1997). Two Islands in the Ocean: Prehistoric Obsidian Exchange between Sakhalin and Hokkaido, Northeast Asia. Journal of Island and Coastal Archaeology 2: 99-120.

Kuzmin, Y. V., Tabarev, A. V., Popov, V. L., Glascock, M. D., and Shackley, M. S. (1999). Geochemical Source Analysis of Archaeological Obsidian in Primorye (Russian Far East). Current Research in the Pleistocene 16: 97-99.

Mahdavi, A. and Bovington, C. (1972). Neutron Activation Analysis of Some Obsidian Samples from Geological and Archaeological Sites. Iran 10: 148-151.

Merrick, H. and Brown, F. (1984). Rapid Chemical Characterization of Obsidian Artifacts by Electron Microprobe Analysis. Archaeometry 26(2):230-236.

Merrick, H., Brown, F., and Nash, W. (1994). Use and Movement of Obsidian in the Early and Middle Stone Ages of Kenya and Northern Tanzania. In Childs, S. T. (Ed.), Society, Culture, and Technology in Africa: 29-44. Masca Research Papers in Science and Archaeology.

Negash, A., Shackley, M. S., and Alene, M. (2006). Source Provenance of Obsidian Artifacts from the Early Stone Age (ESA) Site of Melka Konture, Ethiopia. Journal of Archaeological Science 33 (12): 1647-1650.

Neri, L. A. M. (2007). Philippine Obsidian and its Archaeological Applications. Bulletin of the IndoPacific Prehistory Association 27: 154-162.

Neri, L. A. M., Ferguson, J. R., and Glascock, M. D., (2009). Obsidian Sourcing in Philippine Ar- 
chaeology. In Geological Society of America Abstracts with Programs: 553. vol. 41, Portland.

Niknami, K. A., Amirkhiz, A. C. and Glascock, M. D. (2010). Provenance Studies of Chalcolithic Obsidian Artefacts from Near Lake Urmia, Northwestern Iran Using WDXRF Analysis. Archaeometry 52(1):19-30.

Phillips, S. and Speakman, R. (2009). Initial Source Evaluation of Archaeological Obsidian from the Kuril Islands of the Russian Far East Using Portable XRF. Journal of Archaeological Science 36(6): 1256-1263.

Poidevin, J. L. (1998). Les Gisements d'Obsidienne de Turquie et de Trancaucasie: Geologie, Géochimie et Chronométrie. In Cauvin, M.C., Gourgaud, A., Gratuze, B., Arnaud, N., Poupeau, G., Poidevin, J.L., and Chataigner, C. (Eds.), L'obsidienne au Proche et Moyen-Orient: Du Volcan à l'Outil, pp. 105203. BAR International Series 738. Archaeopress, Oxford.

Poidevin, J.L. (1998). Les gisement d'obsidienne de Turque et de Transcaucasie: géologie, géochimie et chronométrie. In Cauvin et al (Eds). 1998: 105-203.

Pullar, J., Yellin, J. and Perlman, I. (1986). Source of Obsidian from Tepe Abdul Hosein as Determined by Neutron Activation Analysis. In Proceedings of the 24th International Archaeometry Symposium: 389-401.

Renfrew, C. (1969). Trade and Culture Process in European Prehistory. Current Anthropology 10(2/3): 151-169.

Renfrew, C. (1970). Trace Element Analysis of Obsidian and Early Neolithic Trade. In International Congress of Prehistoric and Protohistoric Sciences VII vol. 7: 92-94.

Renfrew, C. (1977). The Later Obsidian of Deh Luran: The Evidence of Chogha Sefid. In: Frank Hole, Studies in the Archaeological History of the Deh Luran Plain: The Excavation of Chogha Sefid. In: Hole, 1977: 289-311.

Renfrew, C. and Dixon. J. (1976). Obsidian in Western Asia: A Review. Problems in Economics and Social Archaeology 42: 137-150.

Renfrew, C., Cann, J., and Dixon, J. (1965). Obsidian in the Aegean. Annual of the British School at Athens 60: 225-247.

Renfrew, C., Dixon, J., and Cann, J. (1966). Obsidian and Early Cultural Contact in the Near East. Proceedings of the Prehistoric Society 2: 3072.
Renfrew, C., Dixon, J., and Cann, J. (1968) Further Analysis of Near Eastern Obsidians. Proceedings of the Prehistoric Society 34: 319-331.

Rosania, C. N., Boulanger, M. T., Biró, K. T., Ryzhov, S., Trnka, G., and Glascock, M. D. (2008). Revisiting Carpathian Obsidian. Antiquity [online project gallery] 82 (318).

Sand, C. and Sheppard, P. (2000) Long Distance Prehistoric Obsidian Imports in New Caledonia: Characteristics and Meaning. Comptes Rendus de l'Academie des Sciences - Series IIA Earth and Planetary Science 331(3): 235-243.

Shelford, P., Hodson, F., Cosgrove, M. E., Warren, S. E., and Renfrew, C. (1982). The Obsidian Trade. In Renfrew, C., and Wagstaff, J. M. (Eds.), An Island Polity: The Archaeology of Exploitation in Melos: 182-221. Cambridge University Press.

Summerhayes, G., Bird, J. R., Fullagar, R., Gosden, C., Specht, J., and Torrence, R. (1998). Application of PIXE-PIGME to Archaeological Analysis of Changing Patterns of Obsidian Use in West New Britain, Papua New Guinea. In Shackley, M. S. (Ed.), Archaeological Obsidian Studies: Method and Theory: 129-158. Plenum Press, New York.

Thorpe, O., Warren, S., and Nandris, J. (1984). The Distribution and Provenance of Archaeological Obsidian in Central and Eastern Europe. Journal of Archaeological Science 11(3): 183-212.

Torrence, R. (2004). Now You See It, Now You Don't: Changing Obsidian Source Use in the Willaumez Peninsula, Papua New Guinea. In Cherry, J., Scarre, C., and Shennan, S. (Eds.), Explaining Social Change: Studies in Honour of Colin Renfrew: 115-125. McDonald Institute, Cambridge.

Torrence, R., Swadling, P., Kononenko, N., Ambrose, W., Rath, P., and Glascock, M. D. (2009). Mid-Holocene Social Interaction in Melanesia: New Evidence from HammerDressed Obsidian Stemmed Tools. Asian Perspectives 48 (1): 119-148.

Tykot, R. H. (1995). Prehistoric Trade in the Western Mediterranean: The Sources and Distribution of Sardinian Obsidian, Harvard, Harvard University Press.

Vogel, N., Nomade, S., Negash, A., and Renne, P. (2006). Forensic 40Ar/39Ar dating: A Provenance Study of Middle Stone Age Obsidian Artifacts from Ethiopia. Journal of Archaeological Science 33(12): 1749-1765. 
Voigt, M. M. (1983). Hajji Firuz Tepe, Iran: the Neolithic Settlement. Philadelphia, University Museum, University of Pennsylvania.

Voigt, M. M. (1988). Excavation at Neolithic Gritille. Anatolica XV: 215-232.

Wright, G. A. (1969). Obsidian Analyses and Prehistoric Near Eastern Trade: 7500 to 3500 B.C. Anthropological Papers, Museum of Anthropology, University of Michigan 37.

Wright, G. and Gordus, A. (1969). Distribution and Utilization of Obsidian from Lake Van Sources between 7500 and 3500 BC. American Journal of Archaeology 73 (1): 75-77.

Wright, H. T. (1981). An Early Town on the Deh Luran Plain: Excavations at Tepe Farukhabad. Memoir 13. Ann Arbor, University of Michigan Museum of Anthropology.

Wright, H. T. (2005). Chipped Stone. In: K. Abdi (ed.), Excavations at Operation W263 at Chogha Gavaneh: Report on the First and Second Seasons, 1998-1999. Tehran, Iranian Cultural Heritage Organization, Tehran.

Yalçinkaya, I. (1998). Découvertes paléolithiques en obsidienne en Anatolie orientale. In Cauvin, M.C., Gourgaud, A., Gratuze, B., Arnaud, N., Poupeau, G., Poidevin, J.L., and Chataigner, C. (Eds.), L'obsidienne au Proche et Moyen-Orient: Du Volcan à l'Outil: 235-240. BAR International Series.

Zarins, J. (1990). Obsidian and the Red Sea Trade: Prehistoric Aspects. In Taddei, M. (Ed.), South Asian Archaeology 1987: Proceedings of the Ninth International Conference of the Association of South Asian Archaeologists in Western Eouope: 509-541. Istituto Italiano per il Medio ed Estremo Oriente, Rome.

Zeidi, M. and Conard, N. J. (2013). Chipped stone artifacts from the aceramic Neolithic site of Chogha Golan, Ilam Province, western Iran, In Borrell, F., Ibáńez, J. J. and Molist, M. (Eds.) Stone Tools in Transition: From Hunter-Gatherers to Farming Societies in the Near East 7th Conference on PPN Chipped and Ground Stone Industries of the Fertile Crescent, Universitat Autònoma de Barcelona. Servei de Publicacions: 315-326. 